\title{
Honeywell
}

\section{Evaluation of Cadmium-Free Thick Film Materials on Alumina Substrates}

Federal Manufacturing \& Technologies

L. H. Perdieu

KCP-613-8632

Published September 2009

Final Report

Approved for public release; distribution is unlimited.

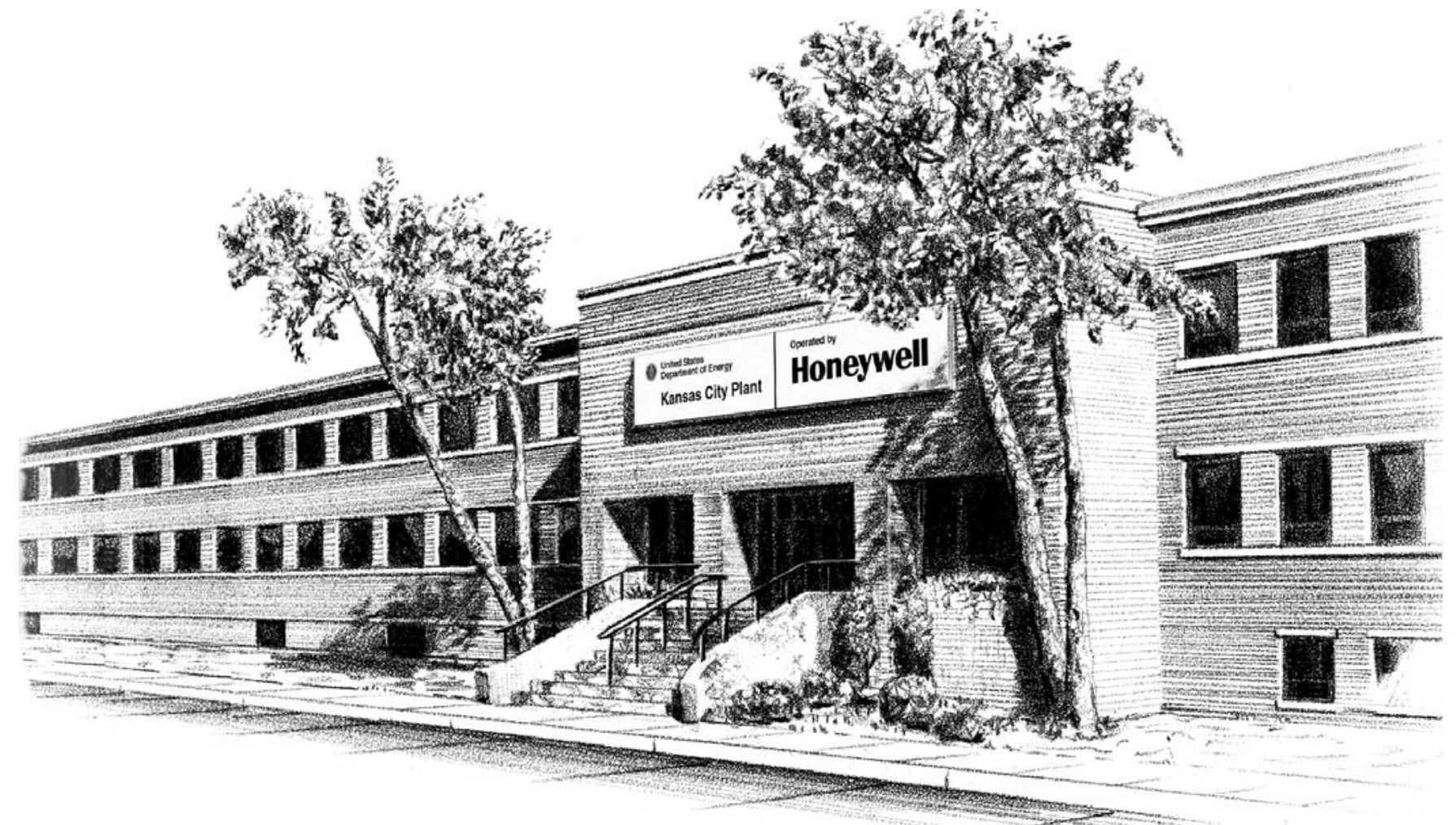




\section{DISCLAIMER}

This report was prepared as an account of work sponsored by an agency of the United States Government. Neither the United States Government nor any agency thereof, nor any of their employees, makes any warranty, express or implied, or assumes any legal liability or responsibility for the accuracy, completeness, or usefulness of any information, apparatus, product, or process disclosed, or represents that its use would not infringe privately owned rights. Reference herein to any specific commercial product, process or service by trade names, trademark, manufacturer, or otherwise, does not necessarily constitute or imply its endorsement, recommendation or favoring by the United States Government or any agency thereof. The views and opinions of authors expressed herein do not necessarily state or reflect those of the United States Government or any agency thereof.

All data prepared, analyzed and presented has been developed in a specific context of work and was prepared for internal evaluation and use pursuant to that work authorized under the reference contract. Reference herein to any specific commercial product, process or service by trade name, trademark, manufacturer, or otherwise, does not necessarily constitute or imply its endorsement, recommendation or favoring by the United States Government, any agency thereof or Honeywell Federal Manufacturing \& Technologies, LLC.

Printed in the United States of America.

This report has been reproduced from the best available copy.

Available to DOE and DOE contractors from the Office of Scientific and Technical Information, P.O. Box 62, Oak Ridge, Tennessee 37831; prices available from (865) 576-8401, FTS 626-8401.

Available to the public from the National Technical Information Service, U.S. Department of Commerce, 5285 Port Royal, Rd., Springfield, Virginia 22161, (703) 487-4650.

A prime contractor with the United States Department of Energy under Contract Number DE-AC04-O1AL66850

\author{
Honeywell Federal Manufacturing \& Technologies \\ P.O. Box 419159 \\ Kansas City, Missouri, 64141-6159
}




\section{Honeywell}

KCP-613-8630

Distribution Category UC-42

Approved for public release; distribution is unlimited.

Evaluation Of Cadmium-Free Thick Film Materials On Alumina Substrates

L. H. Perdieu

Published September 2009

Final Report

Lisa Perdieu, Project Leader

Project Team:

Mike York

Dan Krueger

Cristie Fadner

Sam Bandler

Terry Jones

Jerry Bryant 




\section{Contents}

Section

Page

Abstract.

13

Summary

Discussion

15

Scope and Purpose

Prior Work

16

Activity

Test Plan

16

Test Sample Configuration and Fabrication

Resistor Trim Test Descriptions

18

Resistor Trim Requirements ............................................................... 20

Resistivity Specific Data and Observations................................................ 20

Accomplishments.

Appendices

A Untrimmed DuPont

Resistor Series on Alumina

B Comparative Data $1400 / 2000$

Series on Alumina

C DuPont 15 Resistors on Alumina (Data)

D DuPont 9 Resistors on Alumina (Data)

E DuPont 16 Resistors on Alumina (Data)

F DuPont 17 Resistors on Alumina (Data) 
G DuPont 18 Resistors

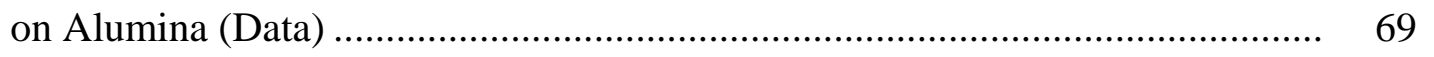

H DuPont 19 Resistors

on Alumina (Data).

76 


\section{Illustrations}

Figure

Page

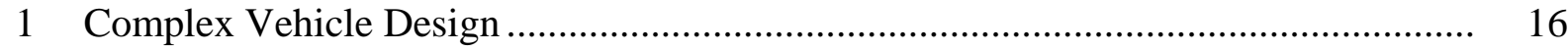

2 Resistor 30 Minute Sintering

Time/Temperature Profile.

3 Resistor 60 Minute Sintering

Time/Temperature Profile.

4 Boxplot of Pull Strengths.

52000 Group Percent Change

in Resistance (10 ohm)

61400 Group Percent Change

in Resistance (10 ohm)

72000 Group Percent Change

in Resistance (100 ohm)

81400 Group Percent Change

in Resistance (100 ohm)

92000 Group Percent Change

in Resistance (1K ohm).....

101400 Group Percent Change

in Resistance (1K ohm).

112000 Group Percent Change

in Resistance (10K ohm).

121400 Group Percent Change

in Resistance (10K ohm).

132000 Group Percent Change

in Resistance (100K ohm).

141400 Group Percent Change

in Resistance (100K ohm).

A-1 Untrimmed Sheet Resistance

(Firing Sensitivity)

A-2 Normalized Sheet Resistance. 
A-3 Untrimmed Sheet Resistance

(Composite Print Lot Variability, 25 mil)

A-4 Untrimmed Sheet Resistance

(Composite Print Lot Variability, 50 mil)

A-5 Untrimmed Sheet Resistance

(Composite Print Lot Variability, 100 mil)

A-6 Untrimmed Sheet Resistance

(Composite Print Lot Variability)

A-7 Encapsulation Sensitivity

(Resistors, 25 mil)

A-8 Encapsulation Sensitivity

(Resistors, 50 mil).

A-9 Encapsulation Sensitivity

(Resistors, 100 mil)

A-10 Resistor Geometry and Orientation

A-11 Resistor Geometry and Orientation (25 mil)

A-12 Resistor Geometry and Orientation (50 mil)

A-13 Resistor Geometry and Orientation (100 mil)

A-14 Resistor Geometry and Orientation

A-15 Resistor Geometry and Orientation (25 mil)

A-16 Resistor Geometry and Orientation (50 mil)

35

A-17 Resistor Geometry and Orientation (100 mil) ......................................................... 36

A-18 Thickness Relationship ..........................................................................................

B-1 Untrimmed Sheet Resistance

Comparison-Furnaces (1400 Series)

B-2 Untrimmed Sheet Resistance

Comparison-Furnaces (2000 Series)

B-3 Untrimmed Sheet Resistance

Comparison-Furnace 20. 
B-4 Untrimmed Sheet Resistance

Comparison-Furnace 21.

B-5 Untrimmed Sheet Resistance

Comparison-Furnace 22 .

C-1 Firing Profile Sensitivity (Resistance) ............................................................. 42

C-2 Firing Profile Sensitivity (Percent) ................................................................. 42

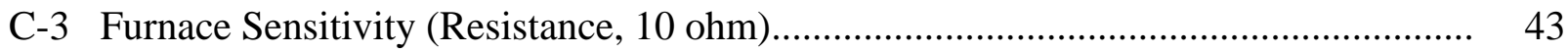

C-4 Furnace Sensitivity (Percent, 10 ohm) .................................................................

C-5 Normalized Sheet Resistance........................................................................ 44

C-6 Normalized Sheet Resistance (Percent) ....................................................... 44

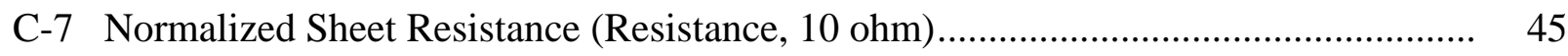

C-8 Normalized Sheet Resistance (Percent, 10 ohm) ............................................. 45

C-9 Thickness and Resistivity Comparison.......................................................... 46

C-10 Thickness and Resistivity

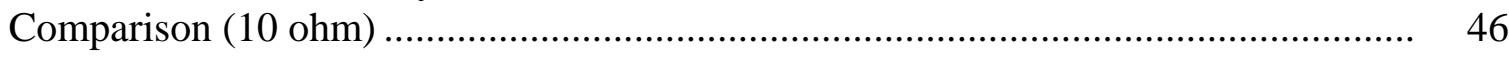

C-11 Thickness Relationship ........................................................................... 47

D-1 Firing Profile Sensitivity

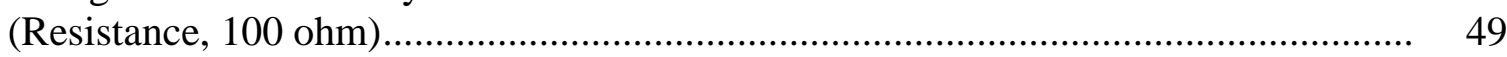

D-2 Firing Profile Sensitivity

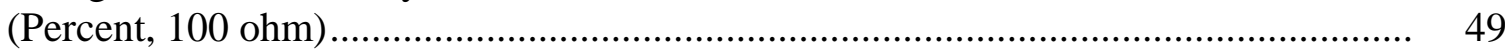

D-3 Furnace Sensitivity

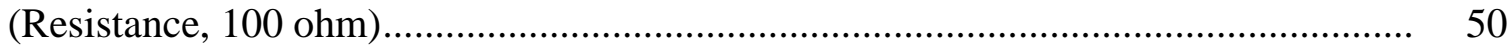

D-4 Furnace Sensitivity

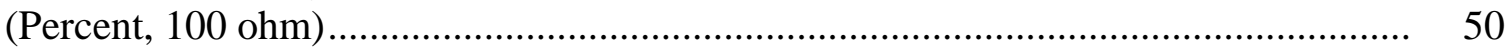

D-5 Normalized Sheet Resistance

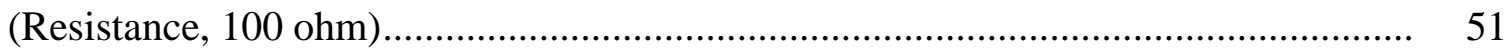

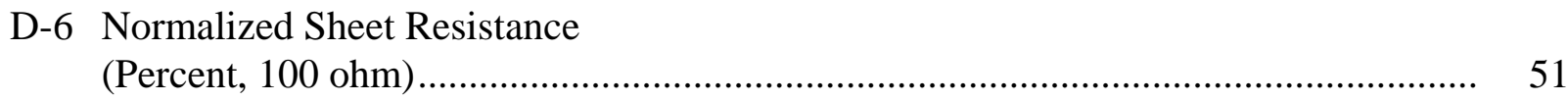

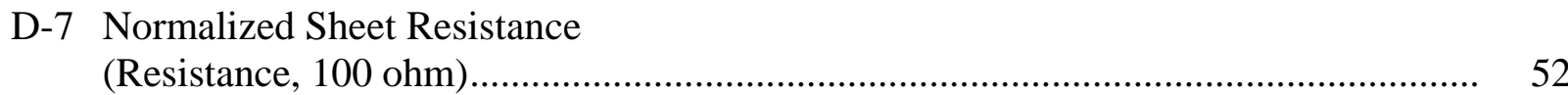


D-8 Normalized Sheet Resistance

(Percent, 100 ohm)

D-9 Thickness and Resistivity

Comparison (Resistance, 100 ohm)

D-10 Thickness and Resistivity

Comparison (Resistance, 100 ohm)

D-11 Thickness Relationship

E-1 Firing Profile Sensitivity

(Resistance, 1K ohm).

E-2 Firing Profile Sensitivity

(Percent, 1K ohm).

E-3 Furnace Sensitivity

(Resistance, 1K ohm)

E-4 Furnace Sensitivity

(Percent, 1K ohm)

E-5 Normalized Sheet Resistance

(Resistance, 1K ohm).

E-6 Normalized Sheet Resistance

(Percent, 1K ohm)

58

E-7 Normalized Sheet Resistance

(Resistance, 1K ohm)

E-8 Normalized Sheet Resistance

(Percent, 1K ohm)

E-9 Thickness and Resistivity

Comparison (Resistance, 1K ohm)

E-10 Thickness and Resistivity

Comparison (Resistance, 1K ohm)

E-11 Thickness Relationship

F-1 Firing Profile Sensitivity

(Resistance, 10K ohm).

F-2 Firing Profile Sensitivity

(Percent, 10K ohm) 
F-3 Furnace Sensitivity

(Resistance, 10K ohm)

F-4 Furnace Sensitivity

(Percent, 10K ohm)

F-5 Normalized Sheet Resistance

(Resistance, 10K ohm).

F-6 Normalized Sheet Resistance

(Percent, 10K ohm)

F-7 Normalized Sheet Resistance

(Resistance, 10K ohm).

F-8 Normalized Sheet Resistance

(Percent, 10K ohm)

F-9 Thickness and Resistivity

Comparison (Resistance, 10K ohm)

F-10 Thickness and Resistivity

Comparison (Percent, 10K ohm)

F-11 Thickness Relationship

68

G-1 Firing Profile Sensitivity

(Resistance, 100K ohm).

G-2 Firing Profile Sensitivity

(Percent, 100K ohm).

G-3 Furnace Sensitivity

(Resistance, 100K ohm).

G-4 Furnace Sensitivity

(Percent, 100K ohm)

G-5 Normalized Sheet Resistance

(Resistance, 100K ohm).

G-6 Normalized Sheet Resistance

(Percent, 100K ohm).

G-7 Normalized Sheet Resistance

(Resistance, 100K ohm).

G-8 Normalized Sheet Resistance

(Percent, 100K ohm) 
G-9 Thickness and Resistivity

Comparison (Resistance, 100K ohm) …………………....................................... 74

G-10 Thickness and Resistivity

Comparison (Resistance, 100K ohm) .................................................................... $\quad 74$

G-11 Thickness Relationship ………………………………......................................

H-1 Firing Profile Sensitivity

(Resistance, 1 meg ohm) ...................................................................................... 77

H-2 Firing Profile Sensitivity

(Percent, 1 meg ohm)

H-3 Furnace Sensitivity

(Resistance, 1 meg ohm) .....................................................................................

H-4 Furnace Sensitivity

(Percent, 1 meg ohm) ………………..................................................................... 78

H-5 Normalized Sheet Resistance

(Resistance, 1 meg ohm)

H-6 Normalized Sheet Resistance

(Percent, 1 meg ohm)

H-7 Normalized Sheet Resistance

(Resistance, 1 meg ohm)

H-8 Normalized Sheet Resistance

(Percent, 1 meg ohm)

H-9 Thickness and Resistivity

Comparison (Resistance, 1 meg ohm)

H-10 Thickness and Resistivity

Comparison (Resistance, 1 meg ohm)

H-11 Thickness Relationship 


\begin{abstract}
A new cadmium-free material system was successfully evaluated for the fabrication of thick film hybrid microcircuits at Honeywell Federal Manufacturing \& Technologies (FM\&T). The characterization involved screen printing, drying and firing two groups of resistor networks which were made using the current material system and the cadmium-free material system. Electrical, environmental and adhesion tests were performed on both groups to determine the more suitable material system. Additionally, untrimmed test coupons were evaluated to further characterize the new materials. The cadmiumfree material system did as well or better than the current material system. Therefore, the new cadmium-free material system was approved for use on production thick film product.
\end{abstract}

\title{
Summary
}

Evaluations were performed on two groups of thick film networks which were manufactured on alumina using the current material system and a cadmium-free material system. After the evaluations, it was determined that the new cadmium-free materials can replace the current materials on future thick film production product. Production use of the cadmium-free compositions on thick film hybrid microcircuits would have several benefits:

- Elimination of existing carcinogenic production materials, specifically DuPont 1400 series resistor compositions, 1 platinum/gold conductor, 2 gold conductor, 3 dielectric, and 4 overglaze;

- Potentially higher production yields and reduced equipment setup times resulting from less process sensitivity of resistor fabrication materials;

- Simplification of material control and production operations by using one common resistor material for both thick film and LTCC resistor fabrication; and

- Ultimate elimination of the DuPont cadmium-bearing compositions from FM\&T production before product availability becomes an issue as a result of low volume sales by DuPont.

The evaluation of DuPont 2000 series resistors printed on alumina was performed for five resistivity compositions $(10,100,1 \mathrm{~K}, 10 \mathrm{~K}$, and $100 \mathrm{~K}$ ohms per square) as a replacement for DuPont 1400 series resistors. DuPont 5 platinum/gold conductor, 6 gold conductor, 7 dielectric, and 8 overglaze were evaluated as replacements for DuPont 1 platinum/gold conductor, 2 gold conductor, 3 dielectric, and 4 overglaze.

The two sets of test samples were printed on $96 \%$ alumina substrates. The overglaze material used on the cadmium-free parts was DuPont 8. The manufacturer recommended overglaze for 2000 series resistors, printed to a dried thickness of 20 microns and fired at $600^{\circ} \mathrm{C}$ for 5 minutes. Resistor termination material used on the DuPont 1400 test samples was DuPont 1 platinum/gold conductor composition, typical of production at FM\&T. Resistor termination material used on the DuPont 2000 test samples was DuPont 5, a platinum/gold cadmium-free conductor composition. 
Test samples for the laser trimming characterization were processed using nominal print thicknesses (23 to 27 microns dried for the 1400 series resistors and 18 to 22 microns dried for the cadmium-free resistors 2000 series). Firing temperature was $850^{\circ} \mathrm{C}$ (30-minute profile). Samples were then subjected to the following tests:

- Isolation resistance;

- 24-hour short-term drift;

- $\quad$ Temperature shock (hot plate shock test): $25^{\circ} \mathrm{C}$ to $268^{\circ} \mathrm{C}, 268^{\circ} \mathrm{C}$ for 15 seconds and back to $25^{\circ} \mathrm{C}$;

- Temperature cycle: $-50^{\circ} \mathrm{C}$ to $125^{\circ} \mathrm{C}$ with approximately 5 seconds ramp time, ten cycles, 15 minutes minimum at each temperature extreme; and

- 200-hour aging test at $150^{\circ} \mathrm{C}$, ambient humidity.

Resistance was measured after each test, and the change in resistance was calculated.

Using visual requirements, isolation resistance, and the results of the above tests, resistor performance was characterized.

The evaluation determined DuPont 2000 series resistors, DuPont 5 platinum/gold conductor, 6 gold conductor, 7 dielectric, and 8 overglaze can be used as an alternative to DuPont 1400 series resistors, DuPont 1 platinum/gold conductor, 2 gold conductor, 3 dielectric, and 4 overglaze in the FM\&T thick film hybrid microcircuit fabrication processes. The evaluation also established the following material characteristics, design criteria, and manufacturing parameters for the five DuPont 2000 series resistor compositions:

1. Target print thicknesses for each of the five pastes ranged from 28 to 32 microns to yield the DuPont recommended dried thickness of 18-22 microns resulting in optimum as-fired resistances and maximum post-trim resistor stability.

2. DuPont 2000 series thick film resistors printed on alumina substrates should be designed to $70 \%$ of trimmed nominal value except for resistors utilizing the $100 \mathrm{ohm}$ (DuPont 9). Based on initial results, resistors employing the $100 \mathrm{ohm}$ (DuPont 9) resistor composition should be designed to $60 \%$ of trimmed nominal value.

3. Average resistances for all five DuPont 2000 series compositions printed on alumina ranged from $54 \%$ above nominal to $9 \%$ below nominal. This range is similar (with the exception of the 100 ohm composition) to DuPont 1400 series resistors (23\% above nominal to $23 \%$ below nominal) used on existing thick film production designs.

4. DuPont 2000 series resistor pastes can be used as an alternative to DuPont 1400 series resistor pastes printed on 96\% alumina substrates using DuPont 5 platinum/gold conductor terminations. 


\section{Discussion}

\section{Scope and Purpose}

The objective of this project was to evaluate a new cadmium-free material system for general purpose thick film printing using DuPont 2000 series resistors terminated with DuPont 5 platinum/gold conductors, isolated with DuPont 7 dielectric, and encapsulated with DuPont 8 overglaze. DuPont 6 gold conductors also were evaluated for use as a lower resistivity conductor material. The project objective evolved primarily due to the following:

- A need to implement an environmentally safer process by replacing existing cadmiumcontaining materials with cadmium-free materials;

- A need for a thick film resistor fabrication method with less sensitivity to process variations;

- A need to minimize the quantity of materials required at FM\&T to support thick film and post-fire LTCC production work by ultimately using a single material system for both technologies; and

- A need for an alternative thick film resistor material at FM\&T in view of DuPont potentially ceasing production of the DuPont 1400 series resistor materials due to relatively low sales volume.

In the evaluation of all the cadmium-free materials, the intent was to determine the following characteristics for all resistor compositions printed in an effort to improve an existing production capability:

1. Target print thickness consistent with manufacturer's recommendations and compatible with subsequent resistor firing and trimming processes for each resistor composition;

2. Resistor physical design requirements compatible with FM\&T manufacturing processes;

3. Sensitivity of resistance to variations in manufacturing processes, primarily print thickness, firing temperature, and resistor trimming; and

4. Trimmed resistor performance determination, including

- Isolation resistance;

- 24-hour short-term drift;

- Temperature shock (hot plate shock test): $25^{\circ} \mathrm{C}$ to $268^{\circ} \mathrm{C}, 268^{\circ} \mathrm{C}$ for 15 seconds, and back to $25^{\circ} \mathrm{C}$;

- Temperature cycle: $-50^{\circ} \mathrm{C}$ to $125^{\circ} \mathrm{C}$ with approximately 5 seconds ramp time, ten cycles, 15 minutes minimum at each temperature extreme; and

- 200-hour aging test at $150^{\circ} \mathrm{C}$, ambient humidity. 


\section{Prior Work}

A thick film technology was developed to meet the requirements of RF applications and multilayer circuits originally utilizing thick film resistors fabricated from DuPont 1400 series resistor compositions printed on the base $96 \%$ aluminum oxide substrate.

This project examined the DuPont 2000 series resistor compositions for printing on 96\% aluminum oxide substrate utilizing cadmium-free conductor terminations and dielectrics. Printability and compatibility of the new materials also was examined.

\section{Activity}

\section{$\underline{\text { Test Plan }}$}

A plan was developed to perform an evaluation of DuPont 2000 series resistor compositions, DuPont 5 platinum/gold conductor, 6 gold conductor, 7 dielectric and 8 overglaze, drying, firing, and laser trimming integral thick film resistors directly on alumina substrate material within the existing FM\&T thick film technology. The evaluation was to ensure similar performance to existing production thick film technology.

The plan utilized a complex test vehicle design to evaluate the DuPont 2000 series resistor compositions, DuPont 5 platinum/gold conductor, 6 gold conductor, 7 dielectric and 8 overglaze for compatibility. For this evaluation, resistor application processes were centered around DuPont’s recommendations for print thickness and firing parameters.

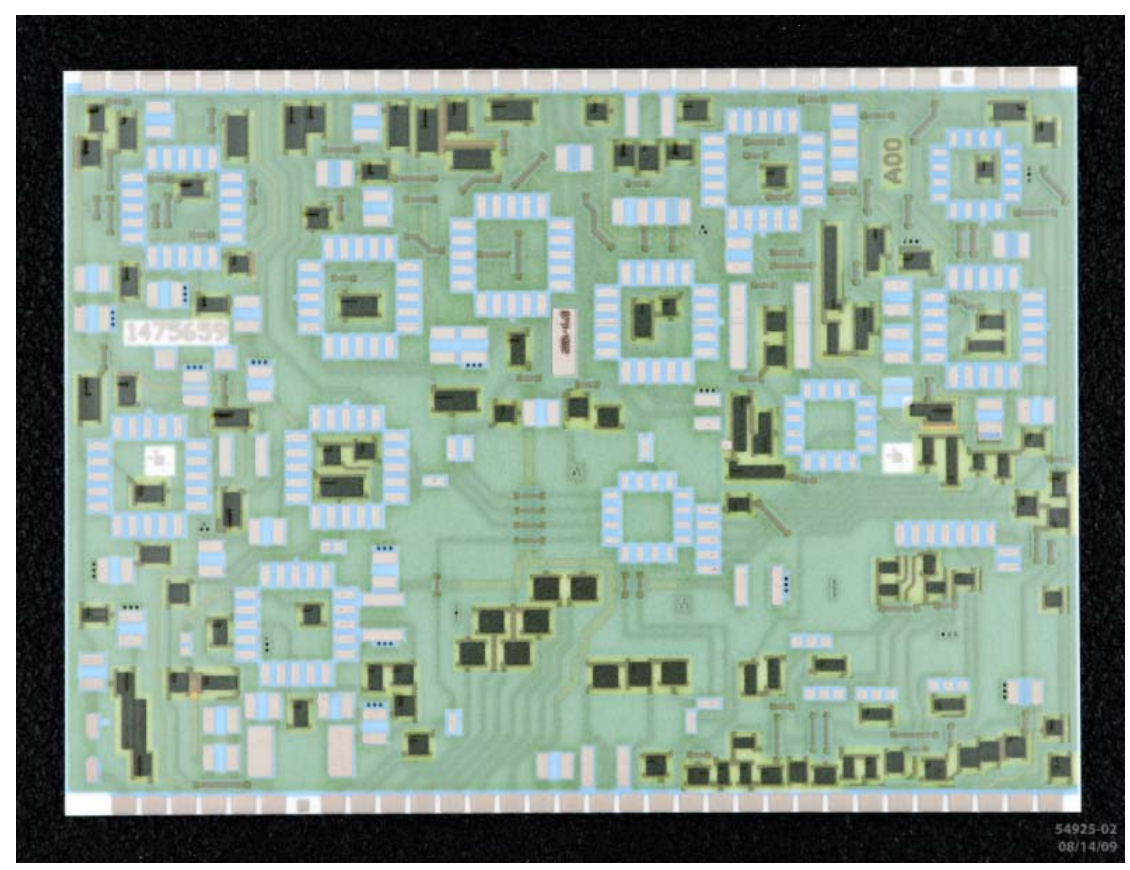

Figure 1. Complex Test Vehicle Design 


\section{Test Sample Configuration and Fabrication}

The evaluation consisted of printing and trimming a complex test vehicle design (Figure 1) that used five resistor compositions, DuPont 10, 11, 12, 13, 14 versus DuPont 15, 9, 16, 17, and 18 on $96 \%$ alumina substrates. The test vehicle substrates were comprised of 0.040 inch thick $96 \%$ alumina. DuPont 1 (old) versus DuPont 5 (new) platinum/gold conductor terminations were used in the evaluation. The test vehicle design was sintered (fired) using the nominal $850^{\circ} \mathrm{C}, 30$ minute profile (Figure 2).

Also untrimmed test coupon sintering (firing) for each resistor composition was performed using the nominal $850^{\circ} \mathrm{C}, 60$-minute profile. The 60 -minute profiles maintain approximate ascent and descent rates of $100^{\circ}$ and $50^{\circ} \mathrm{C}$ per minute, respectively, as illustrated in Figure 3. Test coupons were comprised of 0.025 inch thick $96 \%$ alumina.

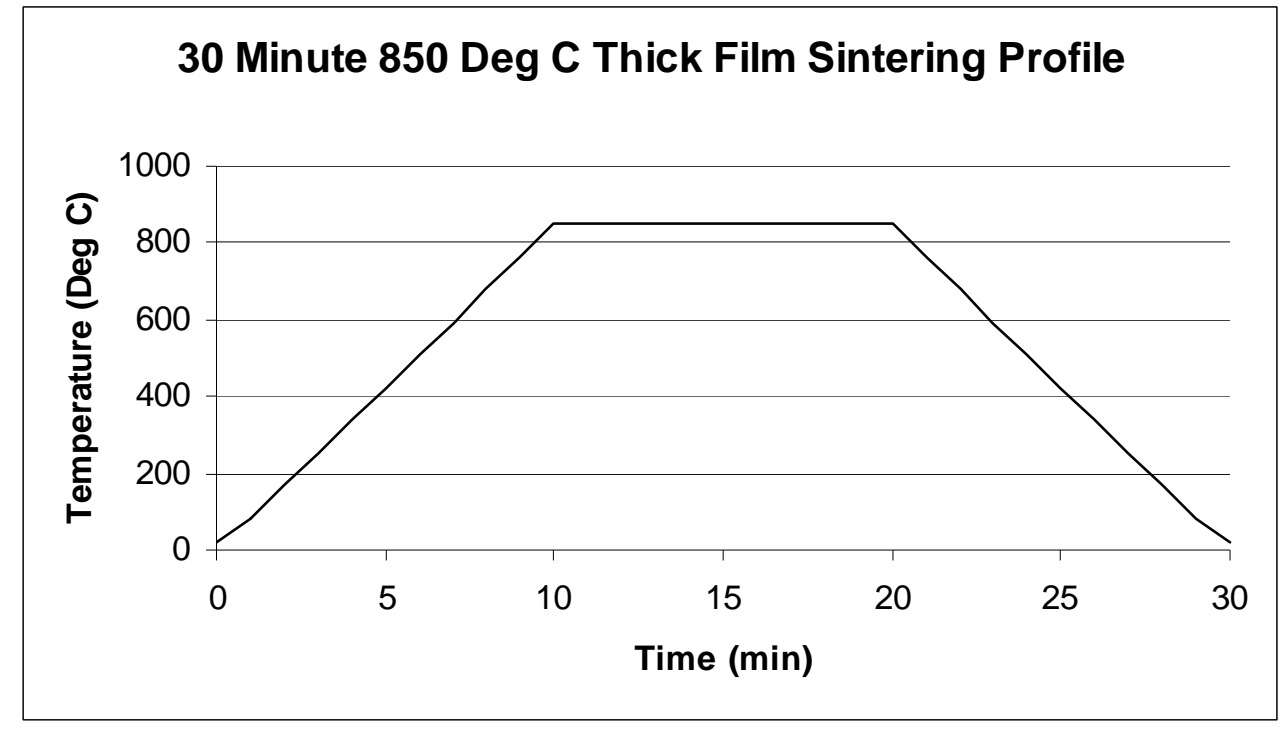

Figure 2. Resistor 30 Minute Sintering Time/Temperature Profile

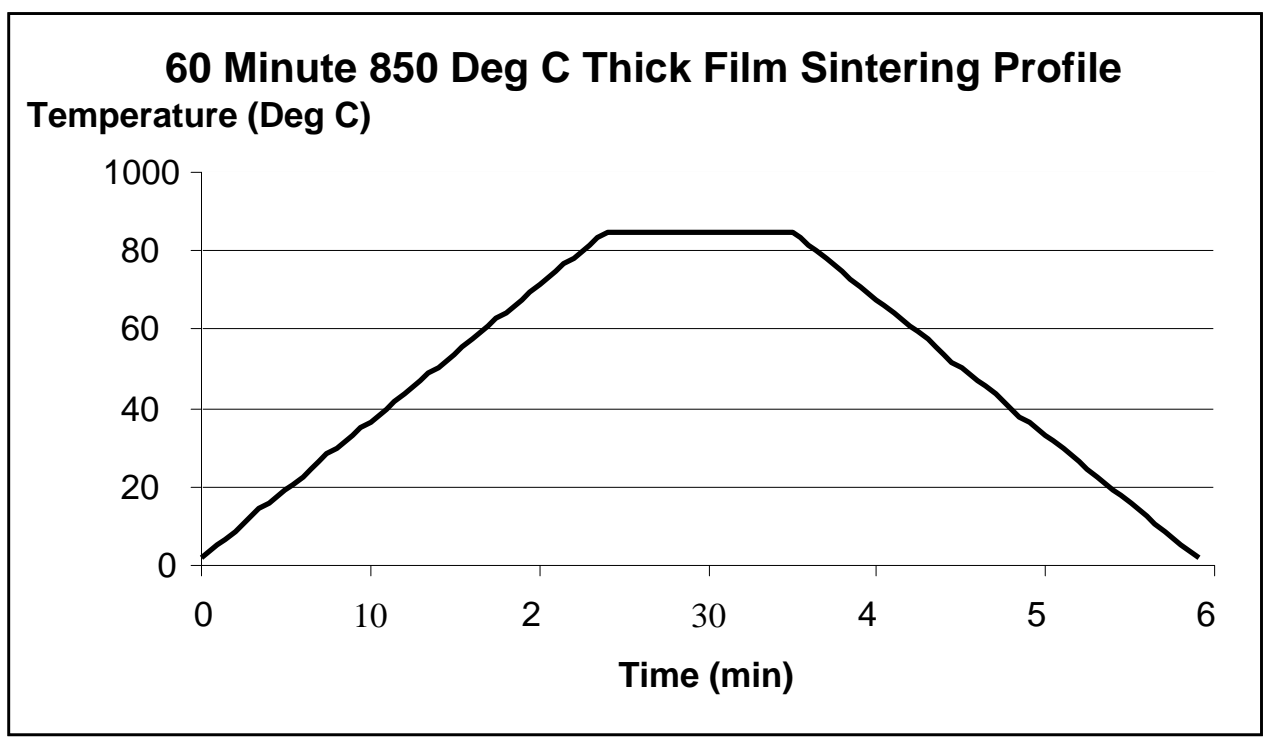

Figure 3. Resistor 60 Minute Sintering Time/Temperature Profile 
The laser-trimmed test vehicle design and the untrimmed test coupons were printed to the dried thickness range recommended by DuPont of 18 to 22 microns for the 2000 series resistor compositions compared to the 23 to 27 micron range for the 1400 series resistor compositions.

\section{$\underline{\text { Resistor Trim Test Descriptions }}$}

The resistor values on all trimmed samples (80 samples, each with 100 resistors) were measured on a General Scanning laser 4-probe system within a few seconds of having been laser trimmed. This measurement will hereafter be referred to as $\mathrm{T} \varnothing$.

The samples were subjected to the following tests.

\section{4-Hour Drift}

The samples were re-measured again approximately 24 hours later, and the change in resistance was calculated. This was done to determine the ability to repeatable measure them and to obtain some measure of their off-the-shelf stability. In past studies of other resistor pastes, the largest change in resistance typically occurred during the first 24 hours. This measurement will be referred to as Ti.

\section{Temperature Shock}

Each sample was then subjected to a temperature shock test. This test involved placing each test sample individually on a hot plate heated to approximately $268^{\circ} \mathrm{C}$ for 15 seconds. The sample was removed and placed on a stainless steel tabletop and allowed to cool to room temperature, approximately $25^{\circ} \mathrm{C}$. All of the resistors were re-measured (Ts), and the change in resistance compared to $\mathrm{T} \varnothing$ was calculated.

\section{Temperature Cycle}

The test samples were then subjected to a temperature cycle test. The test apparatus consisted of two interconnected test chambers. One chamber was set to $-50^{\circ} \mathrm{C}$ while the other was set to $125^{\circ}$ C. A cycle consisted of moving the test samples from one chamber to the other and then back. The approximate transport time was five seconds. The samples were held at each temperature extreme a minimum of 15 minutes. Upon completion of this test, the resistors were again measured (Tc), and the change from $\mathrm{T} \varnothing$ was calculated.

\section{Life Test}

The samples were subjected to the 200 hour aging test. The samples were placed in an oven heated to $150^{\circ} \mathrm{C}$. After 200 hours the samples were removed from the oven and allowed to cool to room temperature. The resistors were measured, and the change compared to T $\varnothing$ was calculated. 


\section{Pull Test}

Pull tests were conducted on the DuPont 1 (old) and 5 (new) conductor materials printed upon 0.025" thick alumina coupons. Two sets of samples were prepared for each conductor material. The "initial" set consisted of samples that had only gone through the printing process. The "aged" set consisted of samples that went through a 48 hour, $150^{\circ}$ centigrade bake. The 1 conductor material for the "initial" samples showed average pull strength of 7.5 lbs. versus the "aged" samples showing average pull strength of 7.6 lbs. While the 5 conductor material showed for the "initial" samples an average pull strength of 6.5 lbs. versus the "aged" samples showing average pull strength of 6.8 lbs. Anything over 2 lbs. is considered acceptable. The boxplot is illustrated in Figure 4.

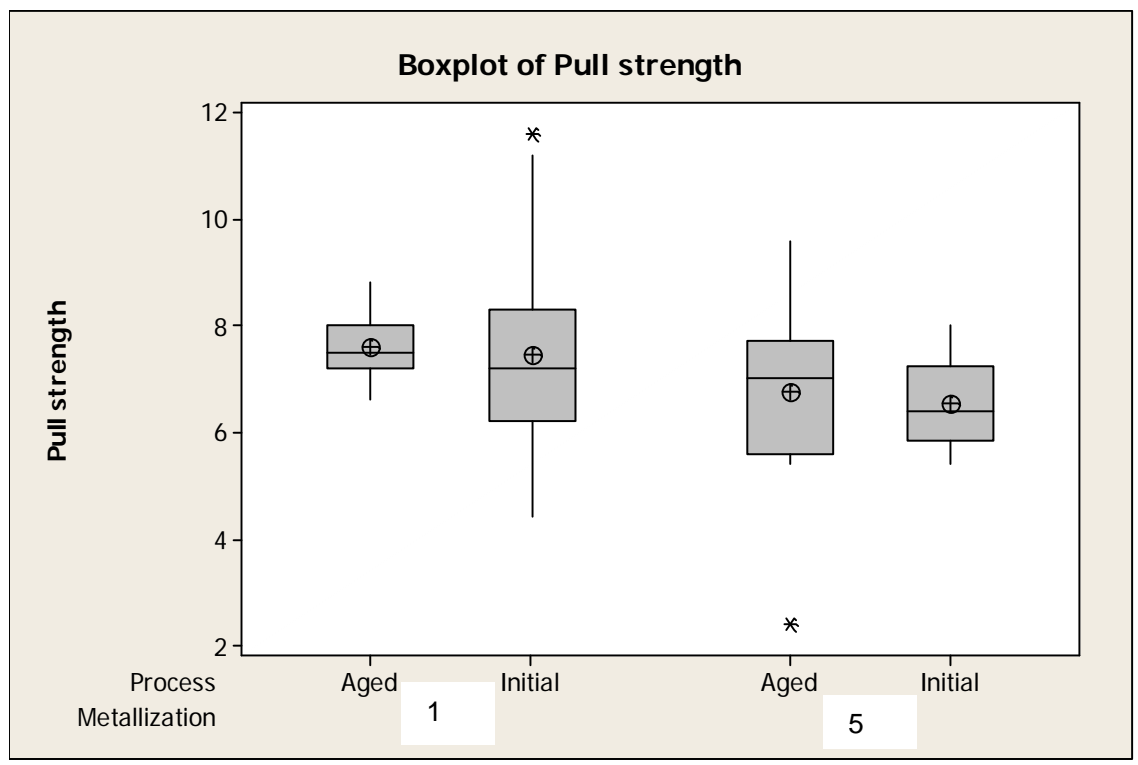

Figure 4. Boxplot of Pull Strengths

\section{Wetting Tests}

Wetting tests were performed on both the DuPont 1 (old) and 5 (new) conductor materials that were printed on $96 \%$ alumina test coupons. There were twelve test parts for each conductor material. The wetting test consisted of slowly dipping the test parts into 63/37 Tin/Lead solder at a temperature of $210^{\circ}$ centigrade. The rating system for the wetting was as follows: $10=$ Excellent wetting, $7=$ Good wetting, 5=Acceptable wetting, $3=$ Poor wetting and $0=$ No wetting. In the first test each part was dipped into the solder only once. For both the 1 and 5 conductor materials on each test part the rating was a 10 (excellent wetting). In the second test each part was dipped ten times into the solder. For both the 1 and 5 conductor materials on each test part the rating was a 10 (excellent wetting). This test showed that both 1 and 5 conductor materials had excellent solderability when printed on alumina. 


\section{$\underline{\text { Resistor Trim Requirements }}$}

Two main requirements were used when considering the ability of a combination of laser parameters to make an acceptable trim. They were visual requirements and isolation resistance.

\section{Visual (Viewed at 30X Magnification)}

- Laser kerf free of obvious debris.

- Laser kerf free of bridges (continuous laser kerf).

- No continuous grooving of the substrate material in the kerf.

- The width of reflowed resistor material on either side of the kerf shall be less than the kerf width.

\section{Isolation Resistance}

Isolation resistance is the value of the resistor that has been cut completely in half. Depending upon the combination of laser parameters selected and the resistor material, the value of the isolation resistance will range from the design value of the resistor to some greater value (typically greater than 32 meg ohms).

The value of the isolation resistance increases from a minimum to some larger value, as the combination of laser parameters is adjusted to cause increasing energy to be applied to the resistor. Increasing the laser energy cuts deeper into the resistor. At some value of laser energy, the resistor material is removed completely from the laser kerf, and there is a several orders of magnitude increase in resistance. This is the minimum laser energy considered sufficient to trim resistors.

\section{Resistivity Specific Data and Observations}

\section{Ohm Resistors (DuPont 15)}

The average percent change in resistance from $\mathrm{T} \varnothing$ to 200 hours for the 10 ohm DuPont 2000 series resistor composition printed on alumina was $0.25 \%$ compared to the $10 \mathrm{ohm}$ DuPont resistor composition (10) printed on alumina which was $0.16 \%$. 


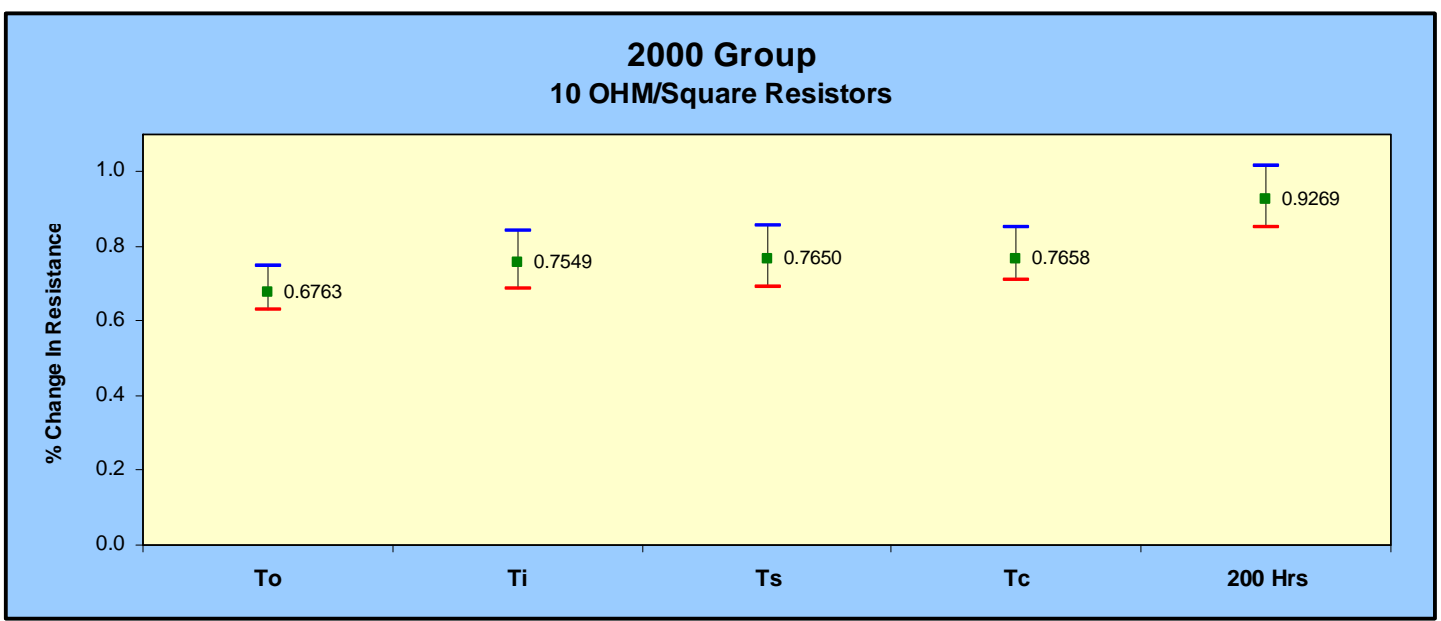

Figure 5. 2000 Group Percent Change in Resistance (10 ohm)

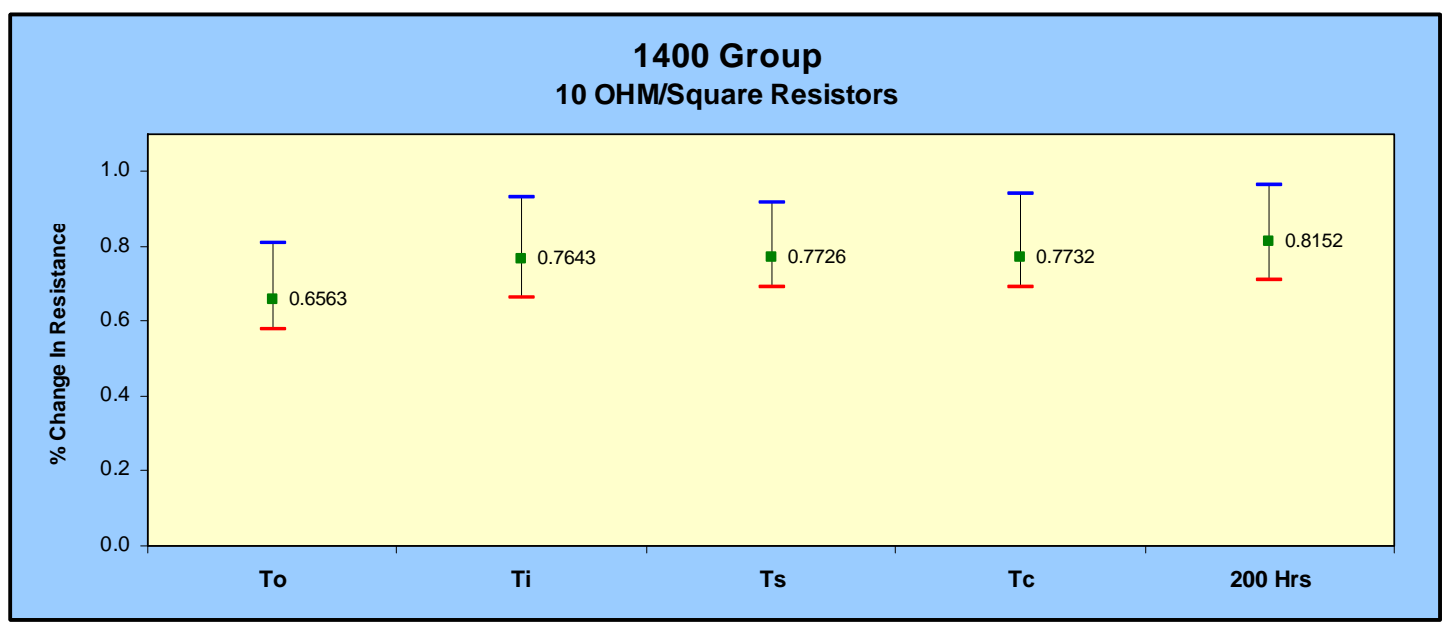

Figure 6. 1400 Group Percent Change in Resistance $(10 \mathrm{ohm})$

\section{Ohm Resistors (DuPont 9)}

The average percent change in resistance from $\mathrm{\varnothing}$ to 200 hours for the $100 \mathrm{ohm}$ DuPont 2000 series resistor composition printed on alumina was $0.07 \%$ compared to the $10 \mathrm{ohm}$ DuPont 1400 series resistor composition (11) printed on alumina, which was $0.23 \%$. 


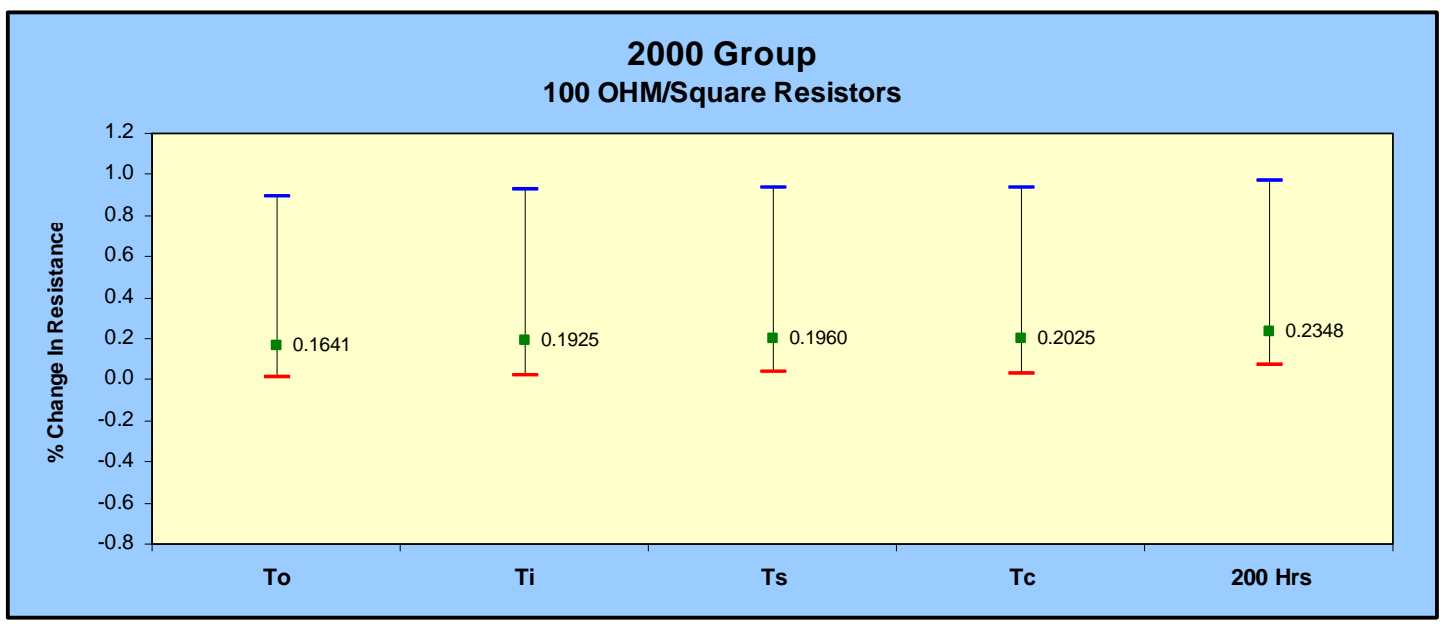

Figure 7. 2000 Group Percent Change Resistance (100 ohm)

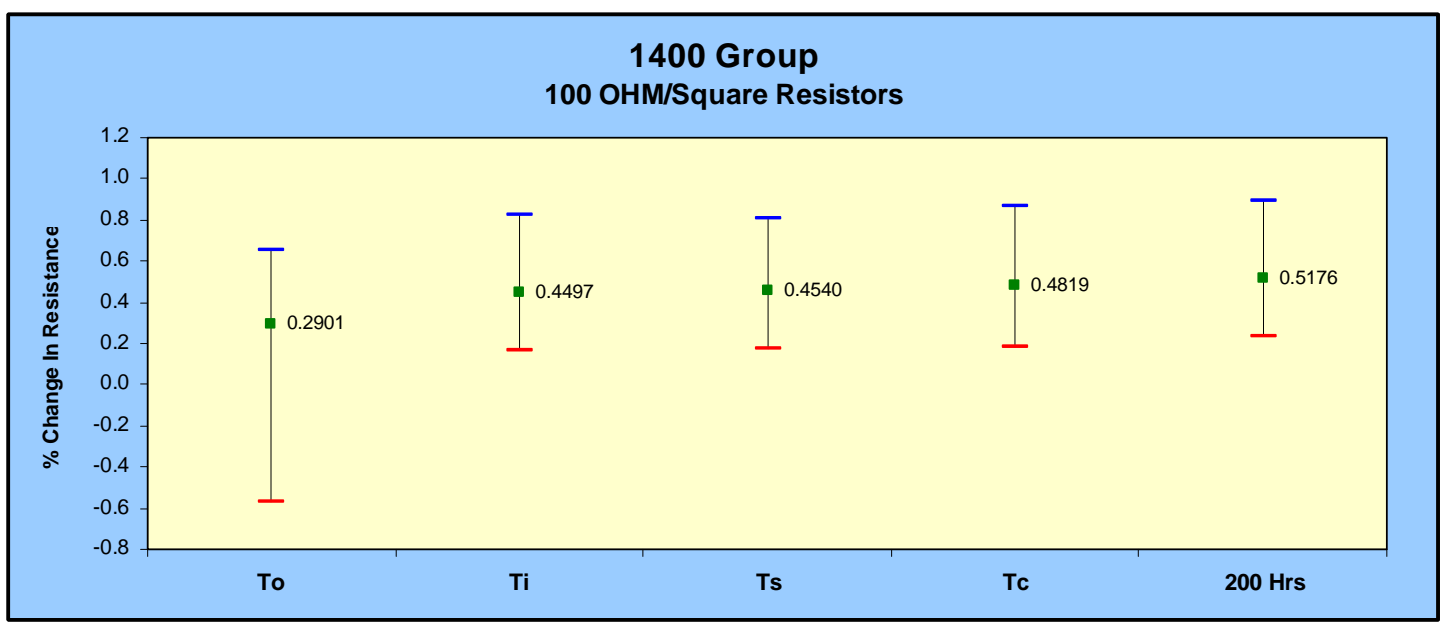

Figure 8. 1400 Group Percent Change Resistance (100 ohm)

\section{K Ohm Resistors (DuPont 16)}

The average percent change in resistance from $\mathrm{T} \varnothing$ to 200 hours for the $1 \mathrm{~K}$ ohm DuPont 2000 series resistor composition printed on alumina was $0.08 \%$ compared to the $1 \mathrm{~K}$ ohm DuPont 1400 series resistor composition (12) printed on alumina, which was $0.12 \%$. 


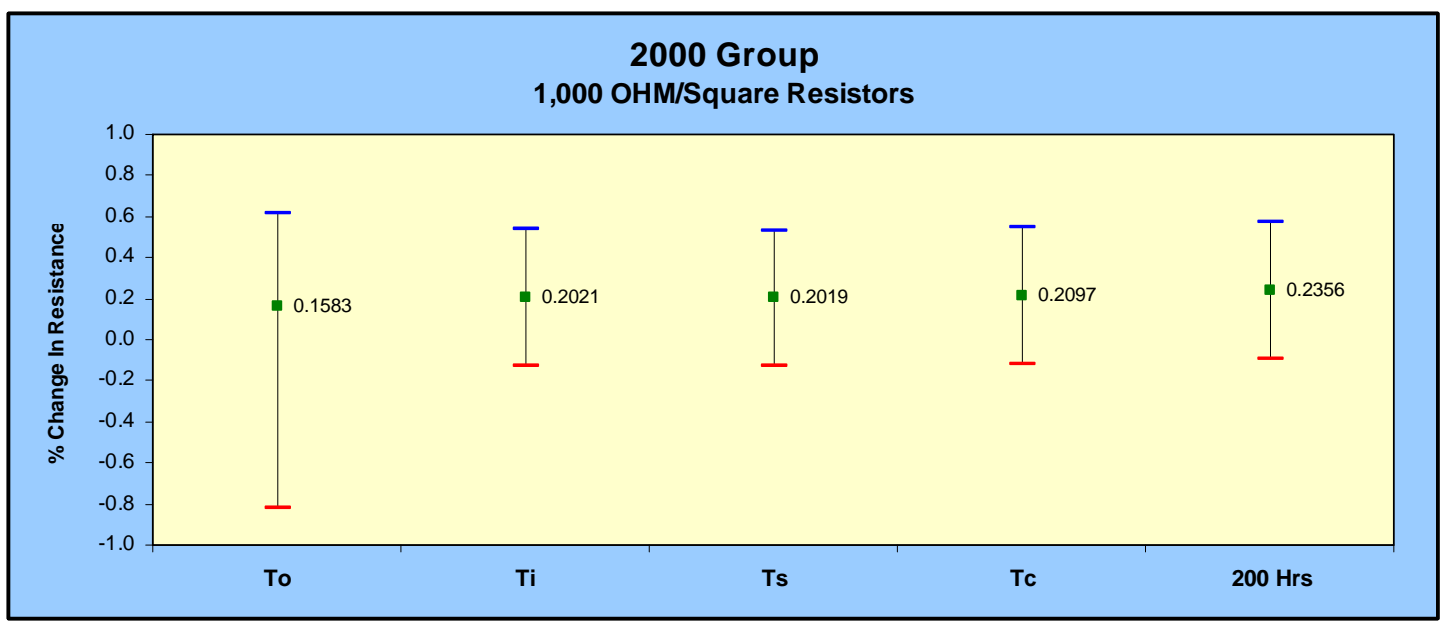

Figure 9. 2000 Group Percent Change Resistance (1K ohm)

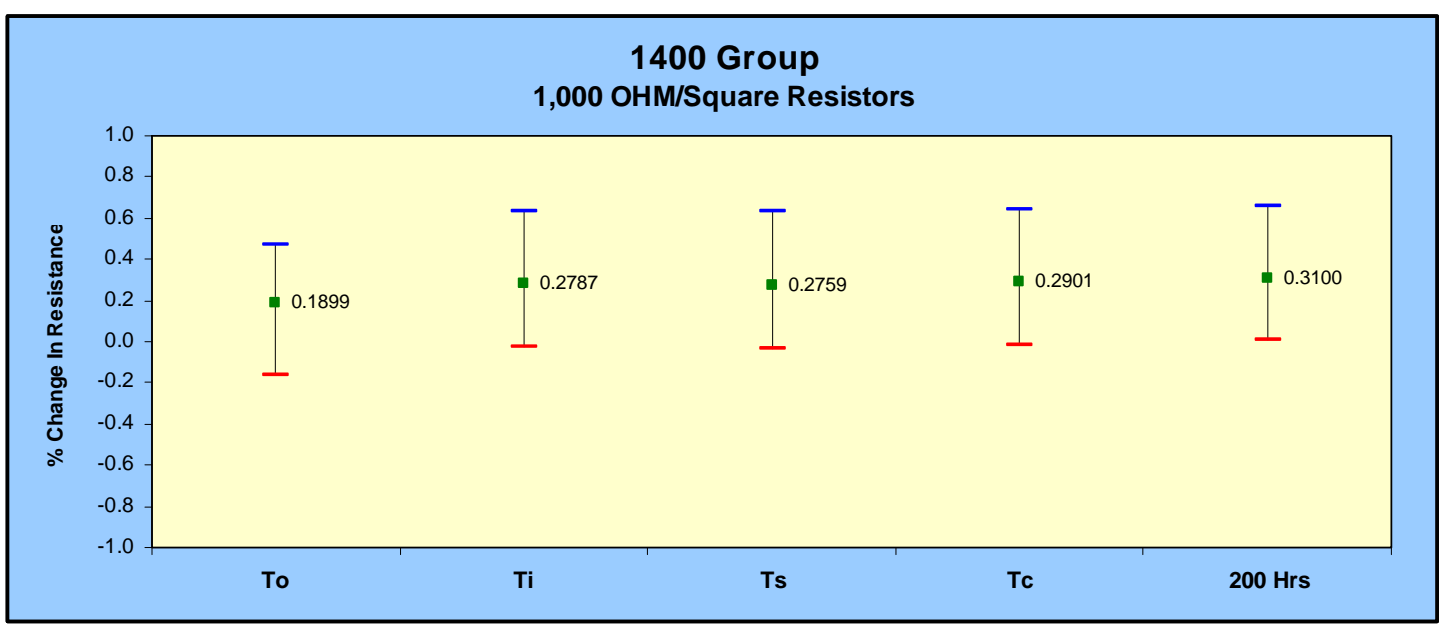

Figure 10. 1400 Group Percent Change in Resistance (1K ohm)

\section{K Ohm Resistors (DuPont 17)}

The average percent change in resistance from T $\varnothing$ to 200 hours for the $10 \mathrm{~K}$ ohm DuPont 2000 series resistor composition printed on alumina was $0.08 \%$ compared to the $10 \mathrm{~K}$ ohm DuPont 1400 series resistor composition (13) printed on alumina, which was $0.13 \%$. 


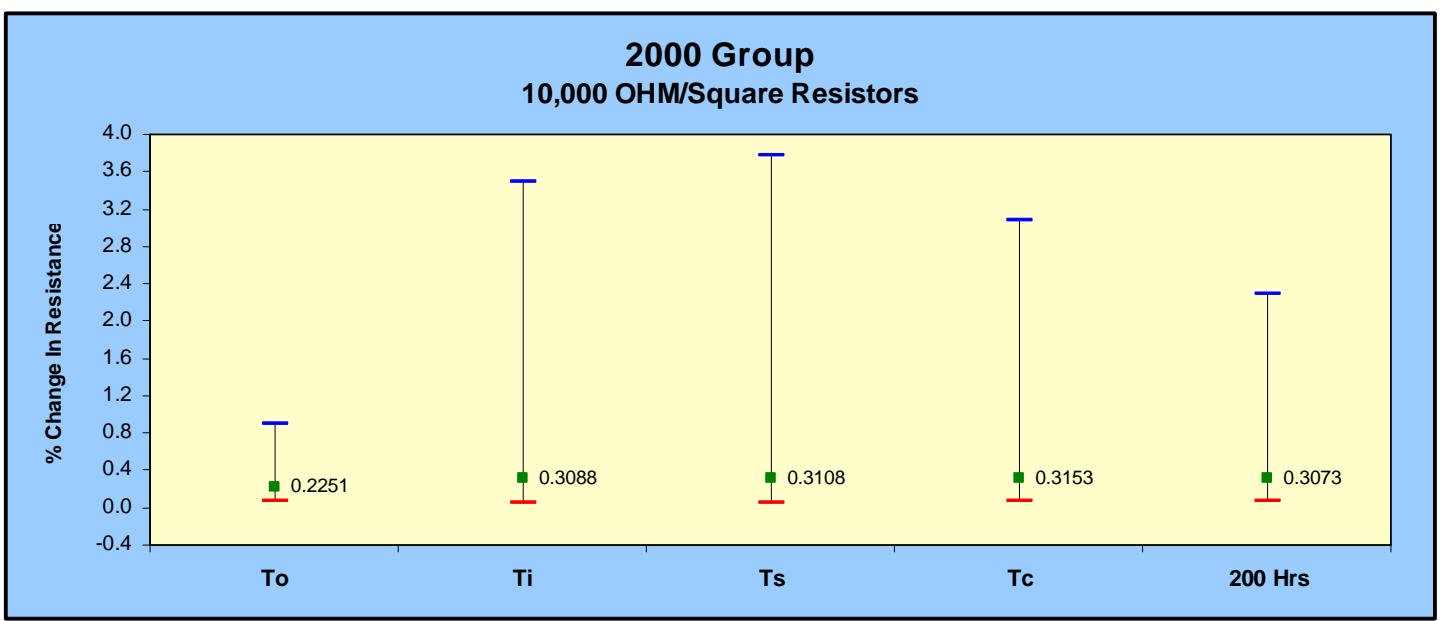

Figure 11. 2000 Group Percent Change in Resistance (10K ohm)

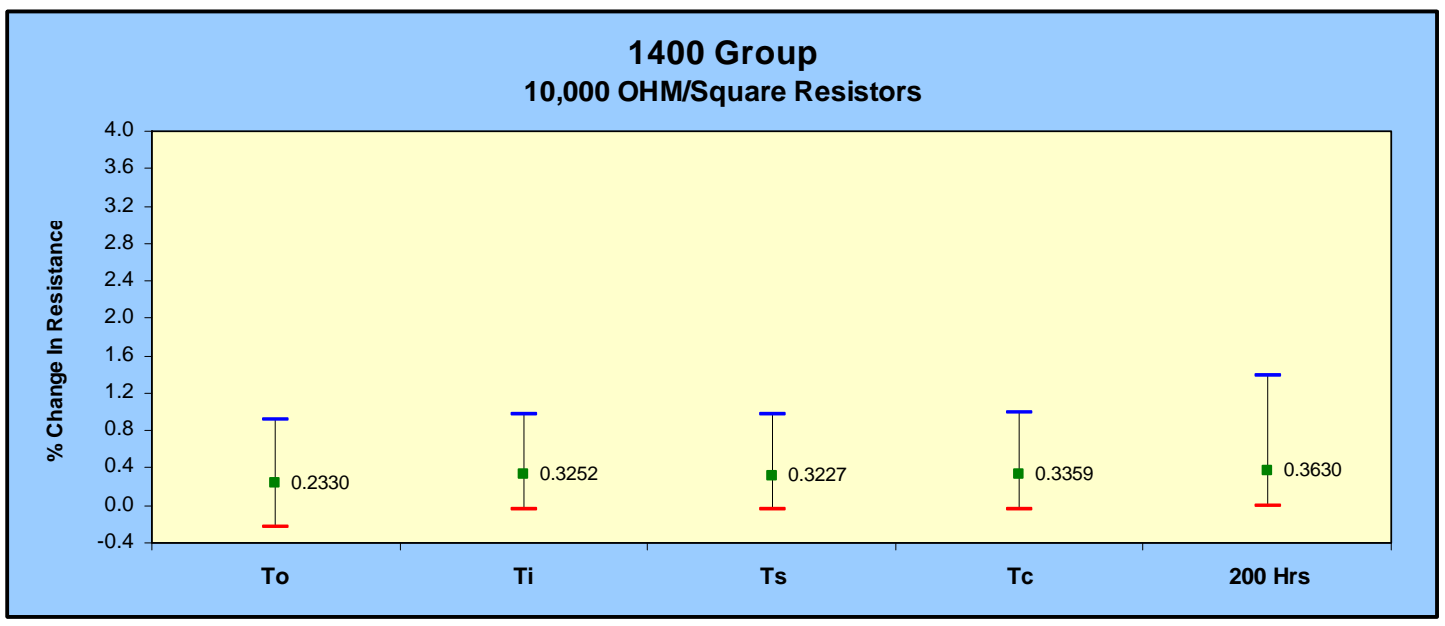

Figure 12. 1400 Group Percent Change in Resistance (10K ohm)

\section{K Ohm Resistors (DuPont 18)}

The average percent change in resistance from $\mathrm{T} \varnothing$ to 200 hours for the $100 \mathrm{~K}$ ohm DuPont 2000 series resistor composition printed on alumina was $0.11 \%$ compared to the $100 \mathrm{~K}$ ohm DuPont 1400 series resistor composition (14) printed on alumina, which was $0.15 \%$. 


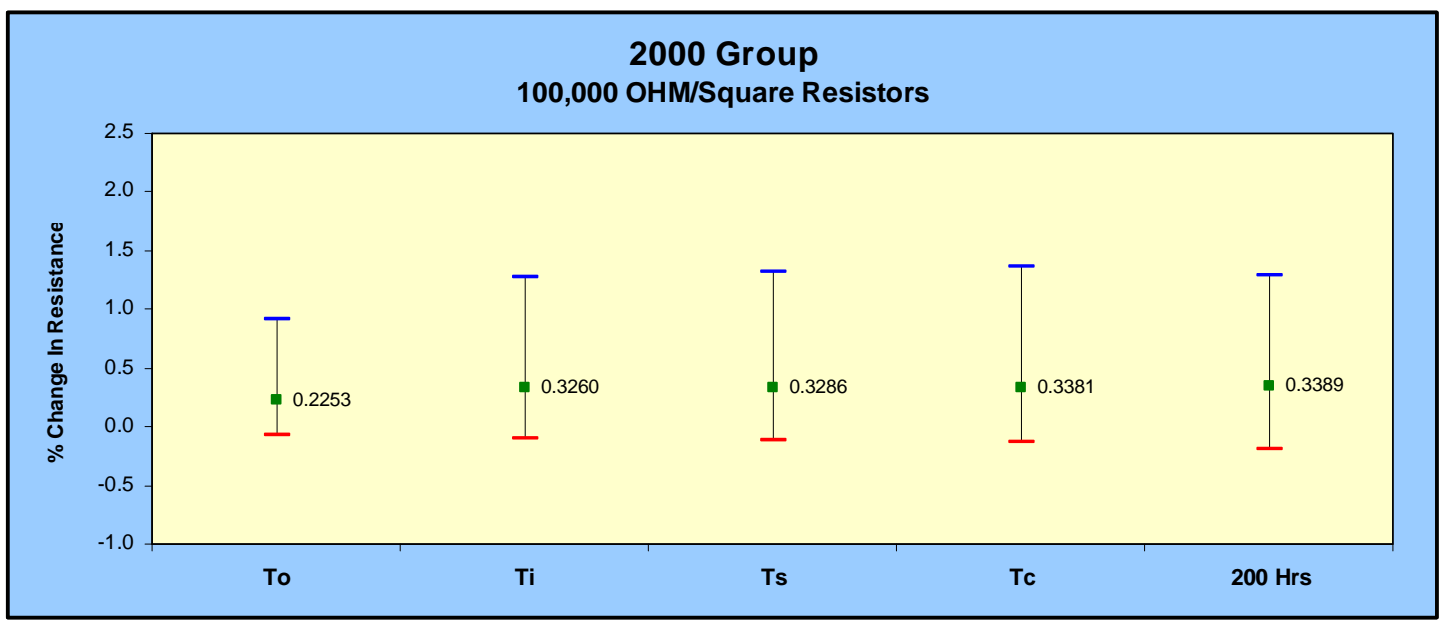

Figure 13. 2000 Group Percent Change in Resistance (100K ohm)

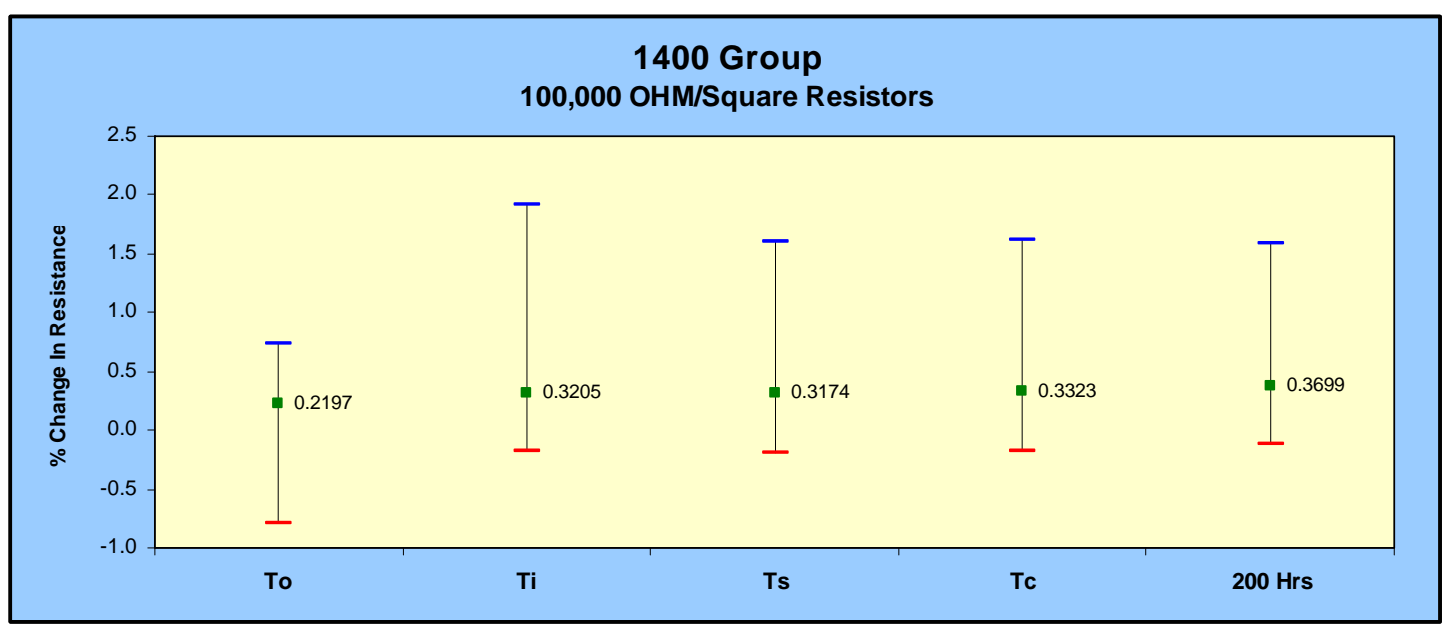

Figure 14. 1400 Group Percent Change in Resistance (100K ohm) 


\section{Accomplishments}

This evaluation has established the following:

- Target print thicknesses and sintering process parameters consistent with the manufacturer's recommendations and compatible with Honeywell manufacturing processes for the five DuPont 2000 series resistor compositions;

- Thick film resistor physical design requirements for applications utilizing DuPont 2000 series resistor compositions printed on alumina substrate material; and

- Resistor stability, for laser trimmed resistors, defined for each resistor paste.

The results of this evaluation indicate DuPont 2000 series resistors can be used to fabricate integral thick film resistors applied to alumina substrates with similar functional characteristics to existing production thick film production technology. Specific recommendations for implementation of DuPont 2000 series resistors printed on alumina are as follows:

- Standard thick film resistor design criteria per DFM Guide 1474328 should be employed for resistors fabricated from DuPont 2000 series resistors; and

- DuPont 2000 series resistor paste is a carcinogen-free alternative to the DuPont 1400 series resistor paste on 96\% alumina substrates, using DuPont 5 platinum/gold conductors in place of DuPont 1 platinum/gold conductors.

The benefits of developing this capability are as follows:

- Ultimate elimination of existing carcinogenic thick film production materials, specifically DuPont 1400 series resistor compositions 1 platinum/gold conductor, 2 gold conductor, 3 dielectric and 4 overglaze;

- Potentially higher production yields and reduced equipment setup times resulting from less process sensitive resistor fabrication materials;

- Simplification of material control and production operations by using one common material system for both thick film and post-fire LTCC fabrication; and

- Alternative capability for production thick film fabrication at FM\&T before product availability becomes an issue as a result of low volume sales of the old DuPont materials. 


\section{Appendix A}

SUMMARY DATA FOR UNTRIMMED DUPONT 2000 RESISTOR SERIES PRINTED ON ALUMINA 


\section{UNTRIMMED SHEET RESISTANCE - DUPONT 2000 SERIES}

Firing Sensitivity - Printed on Alumina (Encapsulated)

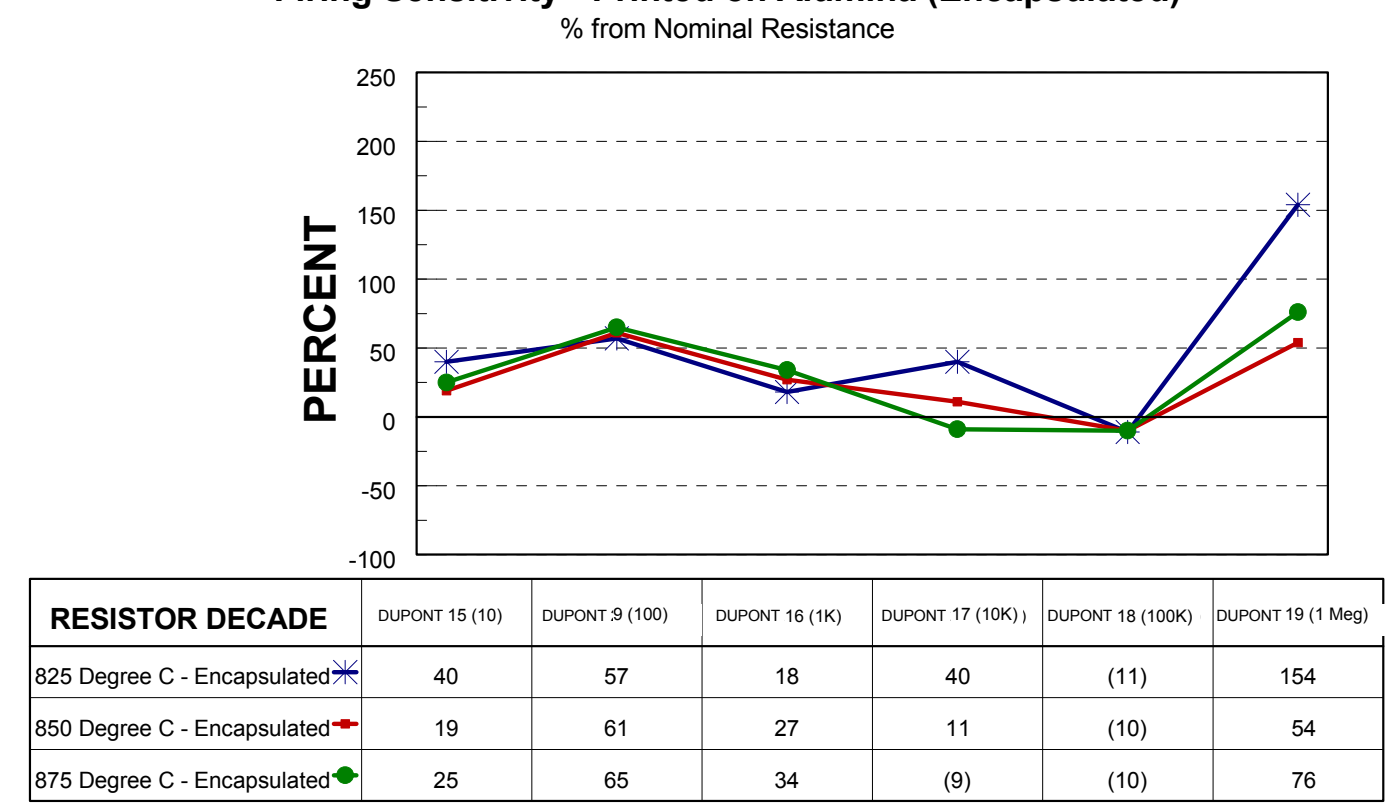

Value in parenthesis is nominal sheet resistance

Dried Target Thickness $=18-20$ microns

Figure A-1. Untrimmed Sheet Resistance (Firing Sensitivity)

\section{NORMALIZED SHEET RESISTANCE - DUPONT 2000 SERIES}

Firing Sensitivity - Printed on Alumina (Encapsulated)

$\%$ from Nominal Resistance

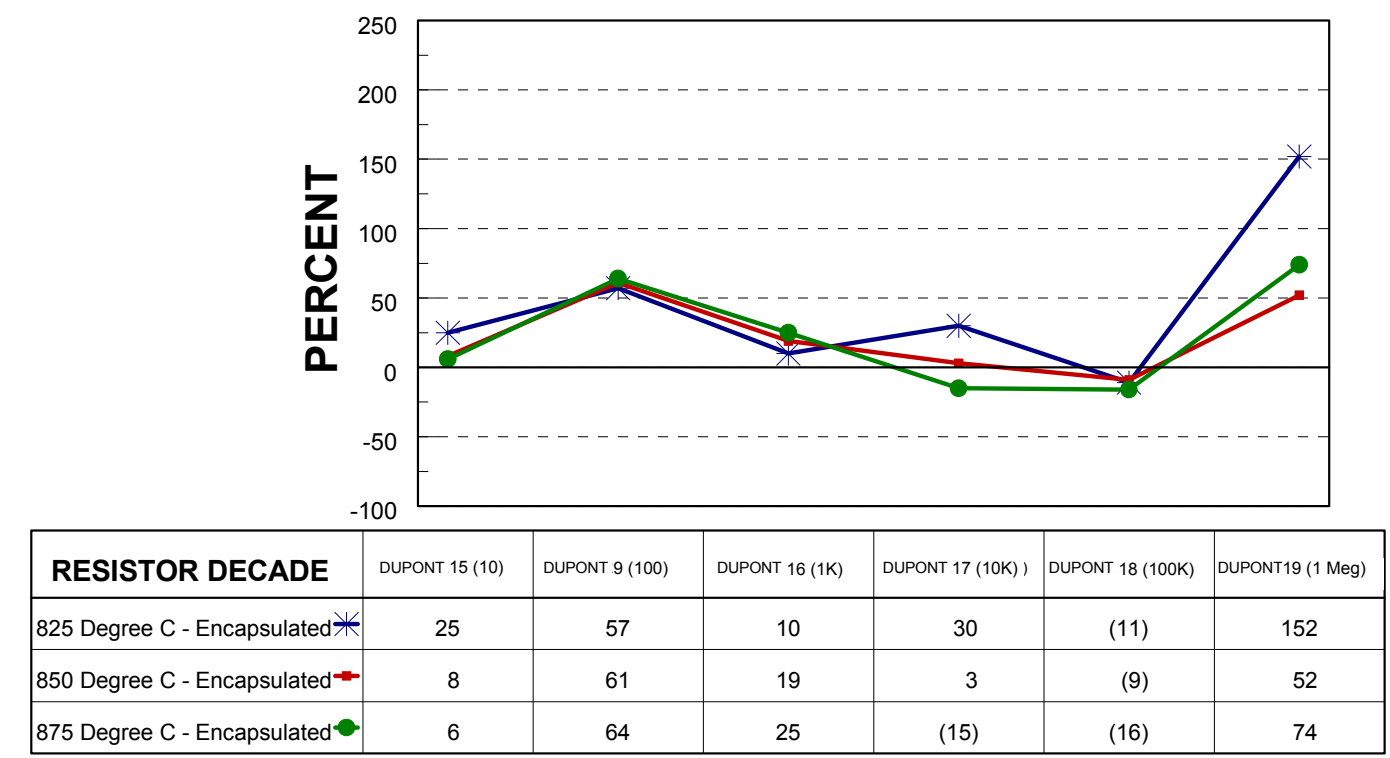

Value in parenthesis is nominal sheet resistance

Data for 50 mil Geometries

Dried Target Thickness $=18-20$ microns

Figure A-2. Normalized Sheet Resistance 


\section{UNTRIMMED SHEET RESISTANCE - DUPONT 2000 SERIES}

Composite Print Lot Variability (Encapsulated - 25 mil Geometries)

$\%$ from Nominal Resistance

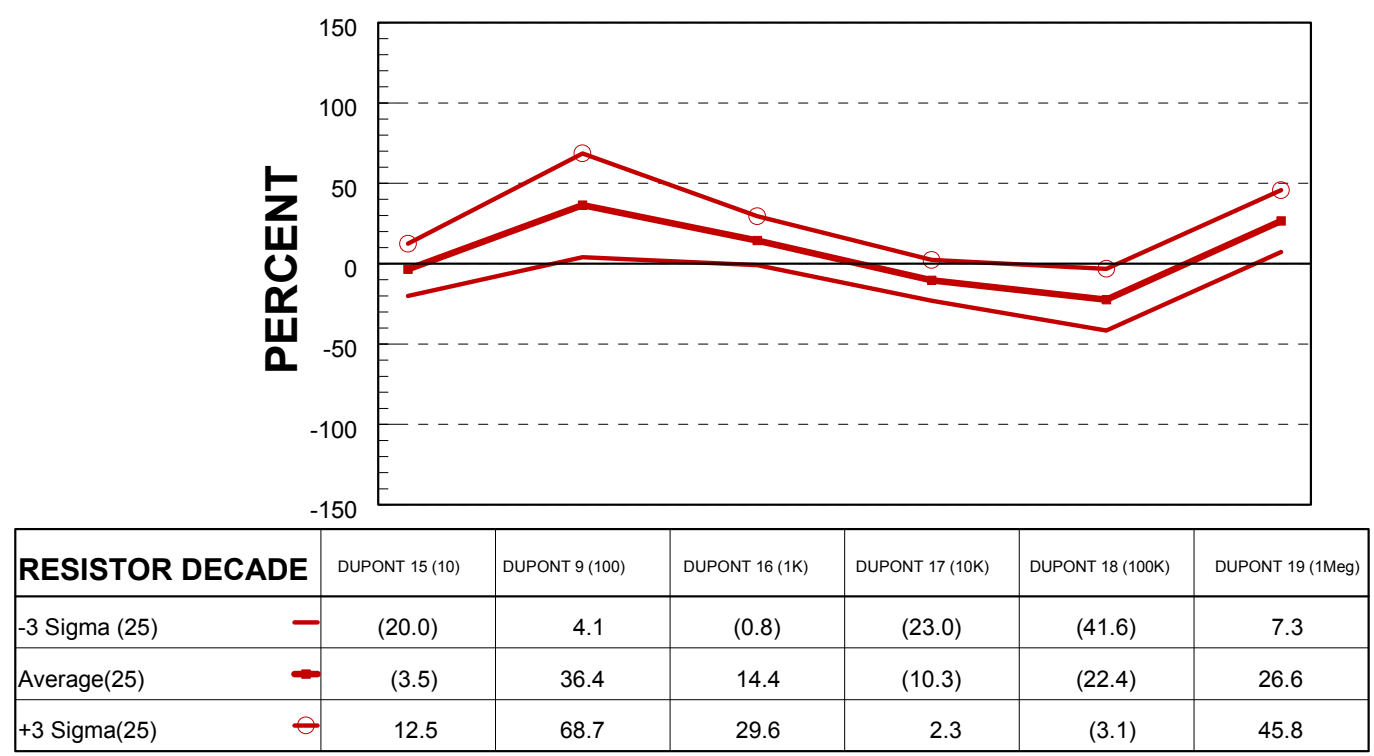

Average +/- 3 Sigma Resistances for 25 mil Geometries

Fired at 850 Degrees C - 30 Minutes

Fired in 21

Figure A-3. Untrimmed Sheet Resistance (Composite Print Lot Variability, 25 mil)

\section{UNTRIMMED SHEET RESISTANCE - DUPONT 2000 SERIES} Composite Print Lot Variability (Encapsulated - 50 mil Geometries)

$\%$ from Nominal Resistance

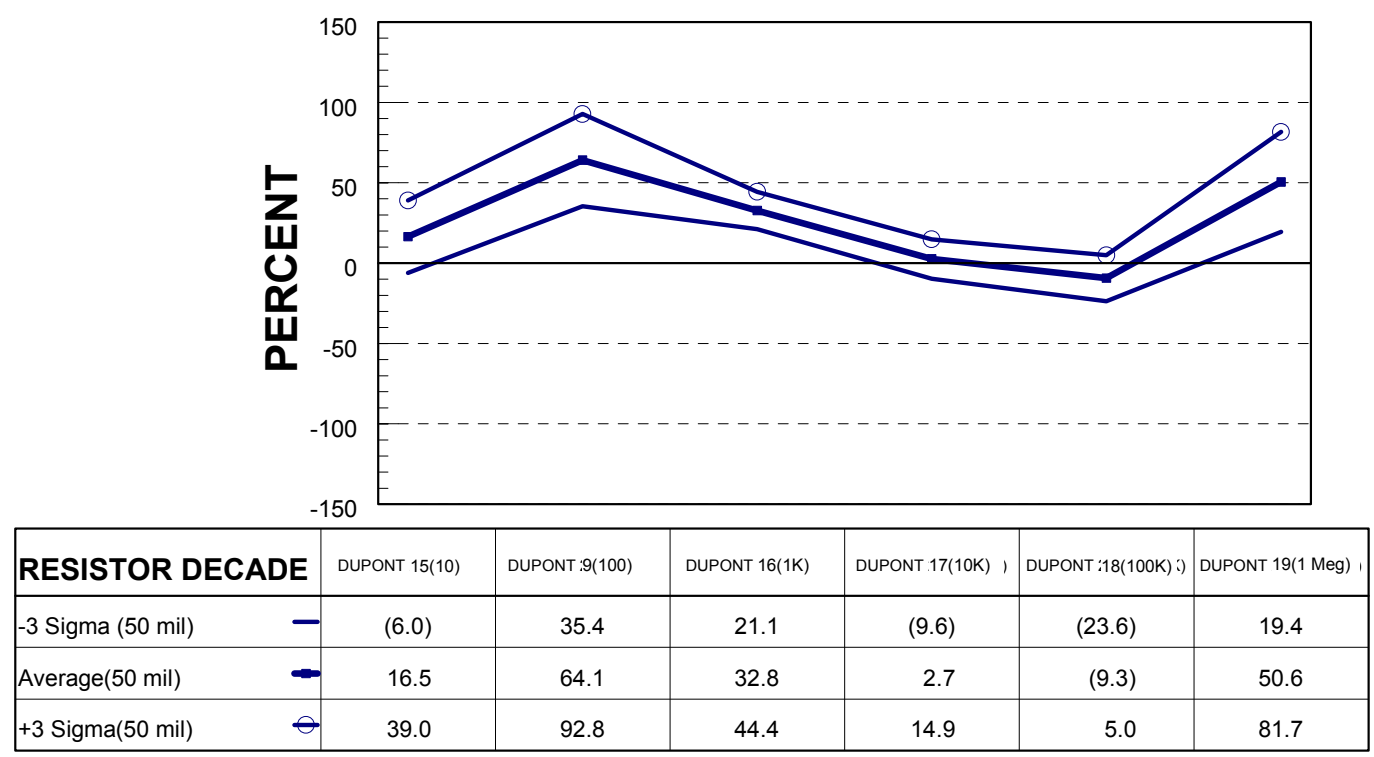

Average +/- 3 Sigma Resistances for 50 mil Geometries

Fired at 850 Degrees C - 30 Minutes

Figure A-4. Untrimmed Sheet Resistance (Composite Print Lot Variability, 50 mil) 


\section{UNTRIMMED SHEET RESISTANCE - DUPONT 2000 SERIES}

\section{Composite Print Lot Variability (Encapsulated - 100 mil Geometries)}

$\%$ from Nominal Resistance

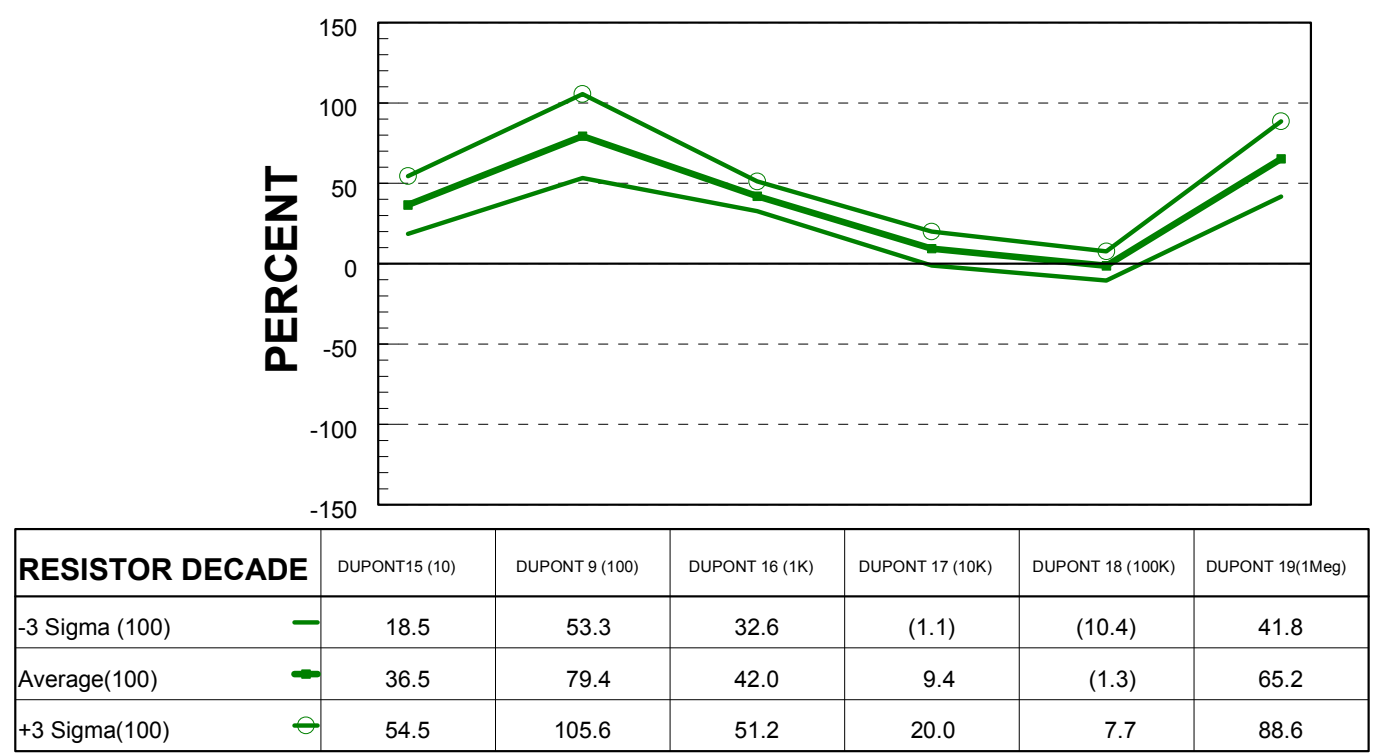

Average +/- 3 Sigma Resistances for 100 mil Geometries

Fired at 850 Degrees $C$ - 30 Minutes

Fired in 21

Figure A-5. Untrimmed Sheet Resistance (Composite Print Lot Variability, 100 mil)

\section{UNTRIMMED SHEET RESISTANCE - DUPONT 2000 SERIES Composite Print Lot Variability (Encapsulated) \\ $\%$ from Nominal Resistance}

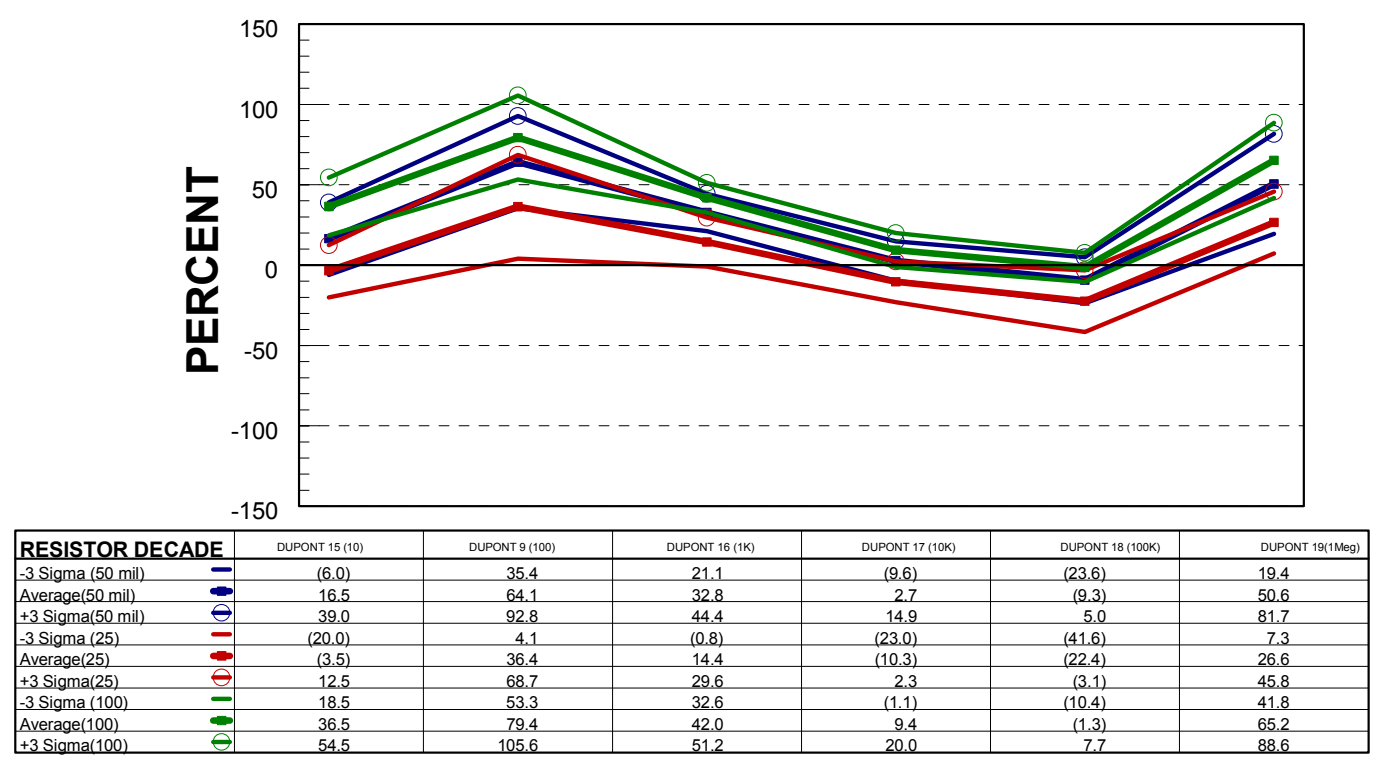

Average +/- 3 Sigma Resistances for All Geometries

Fired at 850 Degrees $\mathrm{C}$ - 30 Minutes

Fired in 21

Figure A-6. Untrimmed Sheet Resistance (Composite Print Lot Variability) 


\section{ENCAPSULATION SENSITIVITY - DUPONT 2000 SERIES}

\section{Resistors Printed on Alumina - 25 mil Geometries}

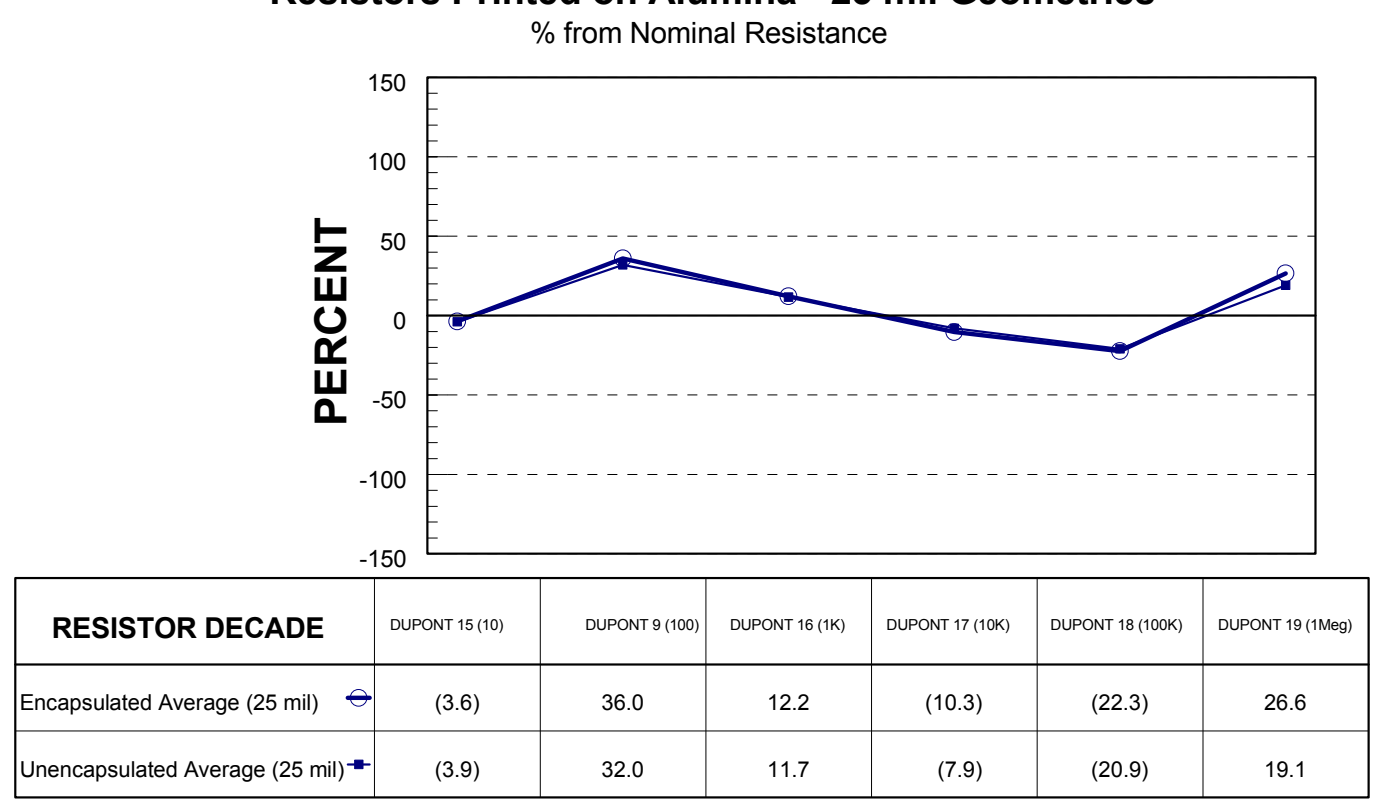

Average Resistances for 25 mil Geometries

Fired at 850 Degrees C - 30 Minutes

Samples fired in 21

Figure A-7. Encapsulation Sensitivity (Resistors, 25 mil)

\section{ENCAPSULATION SENSITIVITY - DUPONT 2000 SERIES}

\section{Resistors Printed on Alumina - 50 mil Geometries}

$\%$ from Nominal Resistance

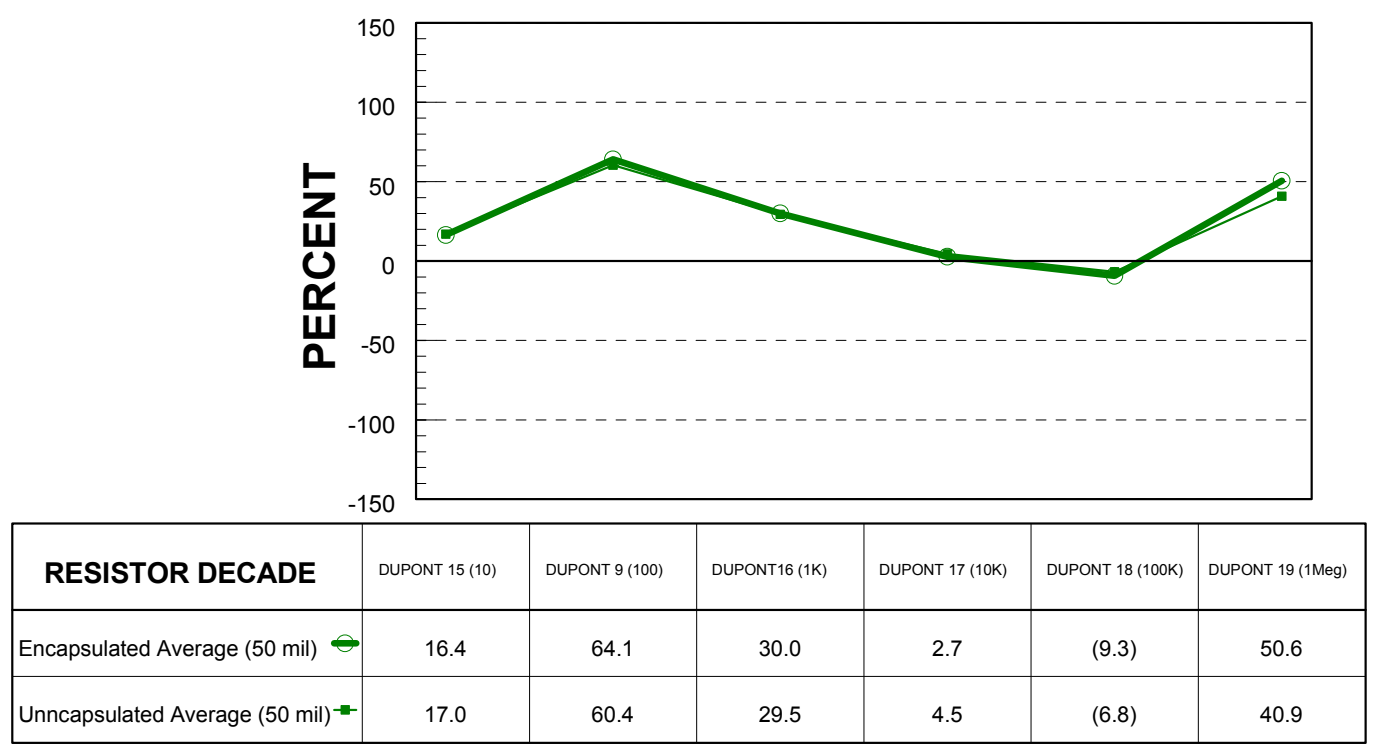

Average Resistances for 50 mil Geometries

Fired at 850 Degrees C - 30 Minutes

Samples fired in 21

Figure A-8. Encapsulation Sensitivity (Resistors, 50 mil) 


\section{ENCAPSULATION SENSITIVITY - DUPONT 2000 SERIES}

\section{Resistors Printed on Alumina - 100 mil Geometries}

$\%$ from Nominal Resistance

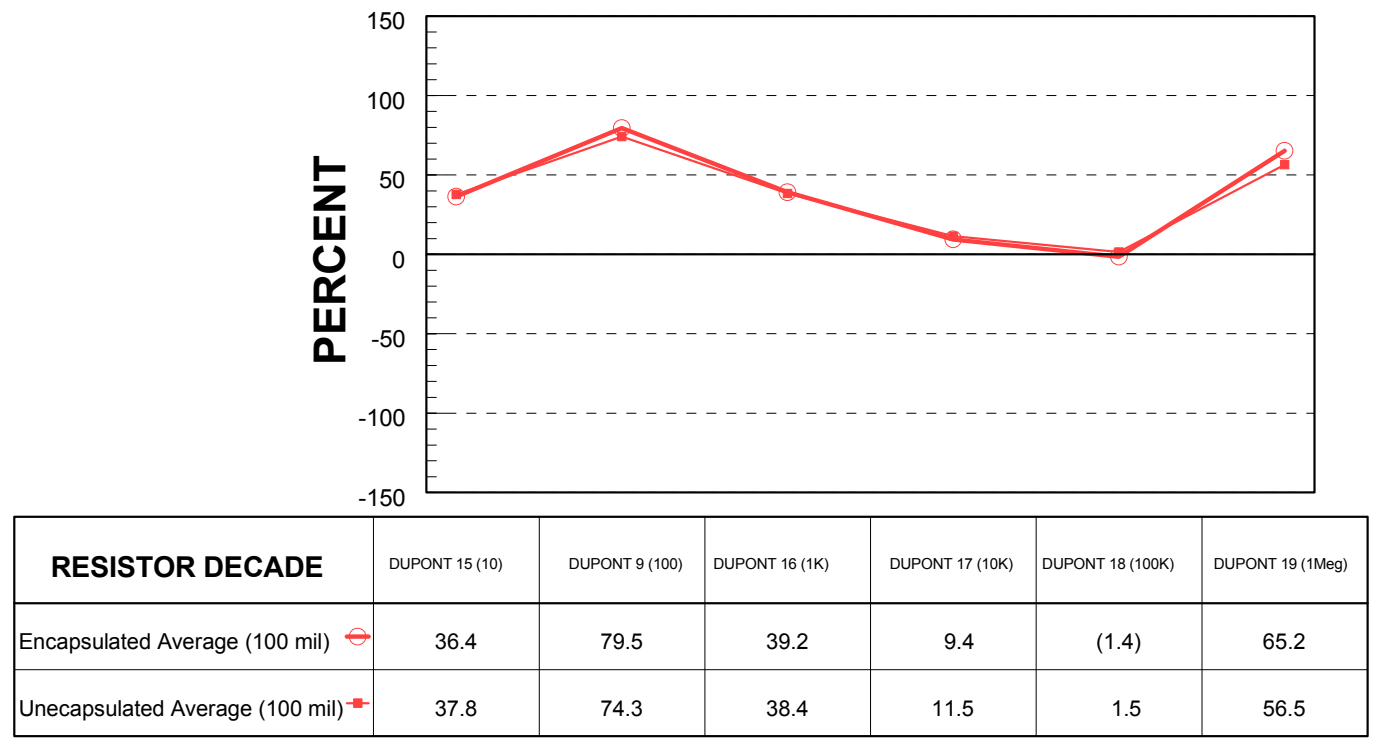

Average Resistances for 100 mil Geometries

Fired at 850 Degrees C - 30 Minutes

Samples fired in 21

Figure A-9. Encapsulation Sensitivity (Resistors, 100 mil)

\section{RESISTOR GEOMETRY \& ORIENTATION}

\section{DuPont 2000 Series Printed on Alumina}

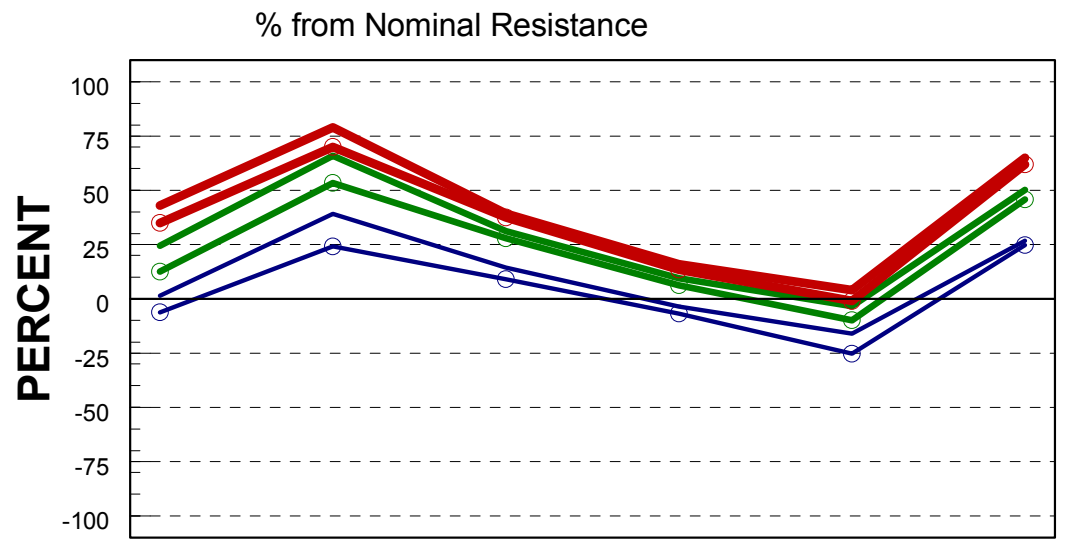

\begin{tabular}{|l|c|c|c|c|c|c|}
\hline RESISTOR DECADE & DUPONT 15 (10) & DUPONT 9 (100) & DUPONT 16 (1K) & DUPONT 17 (10K) & DUPONT 18 (100K) & DUPONT 19 (1Meg) \\
\hline 25 MIL PARALLEL - & $(6.2)$ & 24.2 & 9.1 & $(6.8)$ & $(25.3)$ & 24.8 \\
\hline 25 MIL PERPENDICULAR - & 1.5 & 39.2 & 14.4 & $(3.5)$ & $(16.0)$ & 26.8 \\
\hline 50 MIL PARALLEL - & 12.5 & 53.4 & 27.9 & 6.3 & $(9.8)$ & 45.8 \\
\hline 50 MIL PERPENDICULAR - & 24.5 & 66.0 & 31.2 & 9.5 & $(3.3)$ & 50.2 \\
\hline 100 MIL PARALLEL & 35.0 & 70.0 & 37.5 & 13.5 & $(1.0)$ & 61.9 \\
\hline 100 MIL PERPENDICULAR- & 43.0 & 79.0 & 39.3 & 15.9 & 4.0 & 65.0 \\
\hline
\end{tabular}

Samples were Fired at $850 \mathrm{deg}$. C \& Unglazed

Orientation Refers to Resistor Length Direction

Orientation is Relative to Squeegee Travel

Figure A-10. Resistor Geometry and Orientation 
RESISTOR GEOMETRY \& ORIENTATION DuPont 2000 Series Printed on Alumina - 25 mil Geometries

$\%$ from Nominal Resistance

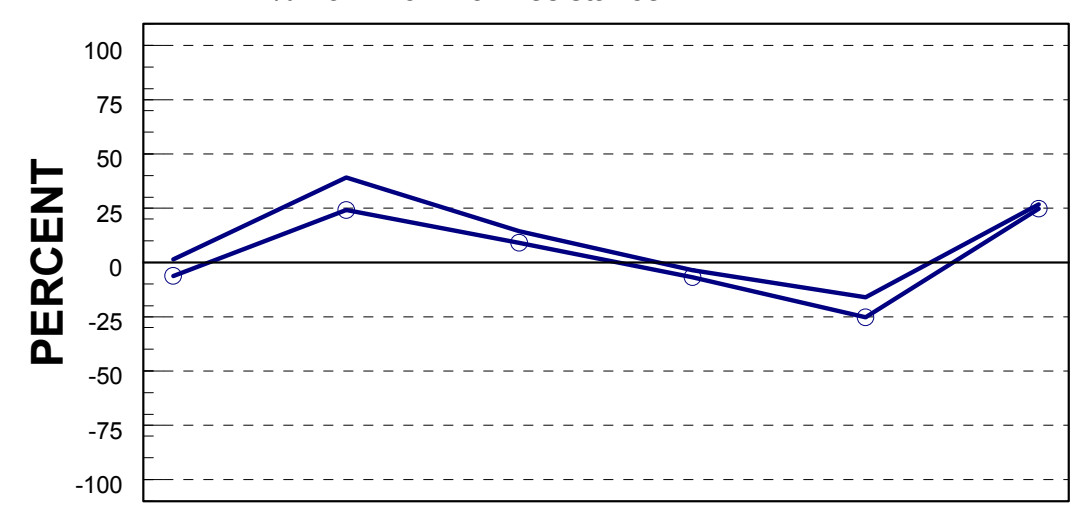

\begin{tabular}{|l|c|c|c|c|c|c|}
\hline RESISTOR DECADE & DUPONT 15 (10) & DUPONT 9 (100) & DUPONT 16 (1K) & DUPONT 17 (10K) & DUPONT 18 (100K) & DUPONT 19 (1Meg) \\
\hline 25 MIL PARALLEL - & $(6.2)$ & 24.2 & 9.1 & $(6.8)$ & $(25.3)$ & 24.8 \\
\hline 25 MIL PERPENDICULAR - & 1.5 & 39.2 & 14.4 & $(3.5)$ & $(16.0)$ & 26.8 \\
\hline
\end{tabular}

Samples were Fired at 850 deg. C \& Unglazed Orientation Refers to Resistor Length Direction Orientation is Relative to Squeegee Travel

Figure A-11. Resistor Geometry and Orientation (25 mil)

\section{RESISTOR GEOMETRY \& ORIENTATION}

\section{DuPont 2000 Series Printed on Alumina - 50 mil Geometries}

$\%$ from Nominal Resistance

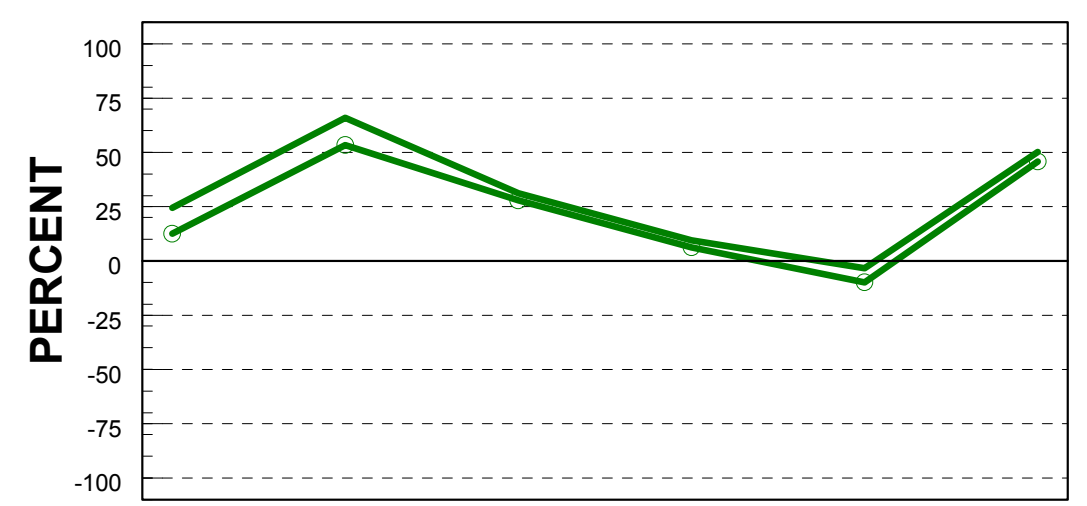

\begin{tabular}{|l|c|c|c|c|c|c|}
\hline RESISTOR DECADE & DUPONT 15 (10) & DUPONT 9 (100) & DUPONT 16 (1K) & DUPONT 17 (10K) & DUPONT 18 (100K) & DUPONT 19 (1Meg) \\
\hline 50 MIL PARALLEL - & 12.5 & 53.4 & 27.9 & 6.3 & $(9.8)$ & 45.8 \\
\hline 50 MIL PERPENDICULAR - & 24.5 & 66.0 & 31.2 & 9.5 & $(3.3)$ & 50.2 \\
\hline
\end{tabular}

Samples were Fired at 850 deg. C \& Unglazed Orientation Refers to Resistor Length Direction Orientation is Relative to Squeegee Travel

Figure A-12. Resistor Geometry and Orientation (50 mil) 


\section{RESISTOR GEOMETRY \& ORIENTATION}

\section{DuPont 2000 Series Printed on Alumina - 100 mil Geometries}

$\%$ from Nominal Resistance

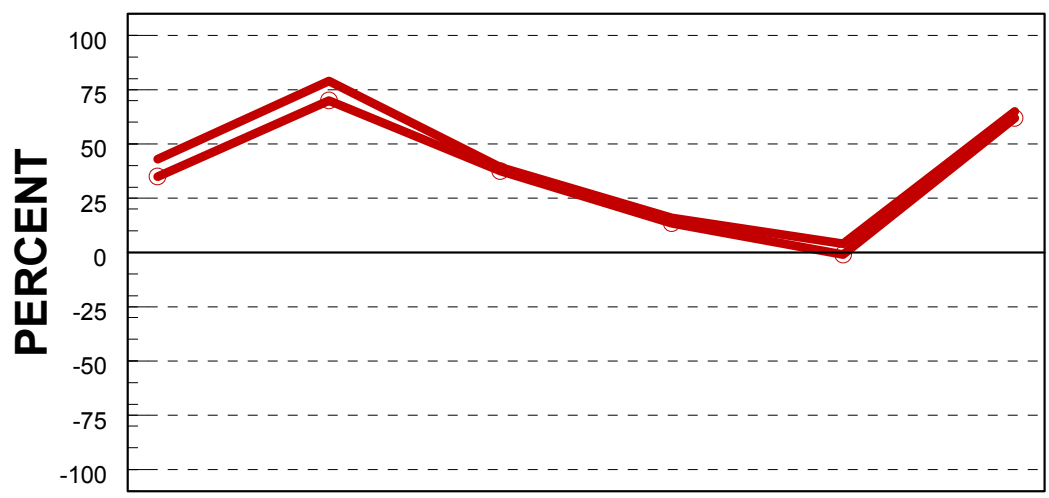

\begin{tabular}{|l|c|c|c|c|c|c|}
\hline RESISTOR DECADE & DUPONT 15(10) & DUPONT 9 (100) & DUPONT 16 (1K) & DUPONT 17 (10K) & DUPONT 18 (100K) & DUPONT 19 (1Meg) \\
\hline 100 MIL PARALLEL & 35.0 & 70.0 & 37.5 & 13.5 & $(1.0)$ & 61.9 \\
\hline 100 MIL PERPENDICULAR & 43.0 & 79.0 & 39.3 & 15.9 & 4.0 & 65.0 \\
\hline
\end{tabular}

Samples were Fired at 850 deg. C \& Unglazed

Orientation is Relative to Squeegee Travel

Figure A-13. Resistor Geometry and Orientation (100 mil)

\section{RESISTOR GEOMETRY \& ORIENTATION}

\section{DuPont 2000 Series Printed on Alumina}

$\%$ from Target Dried Thickness

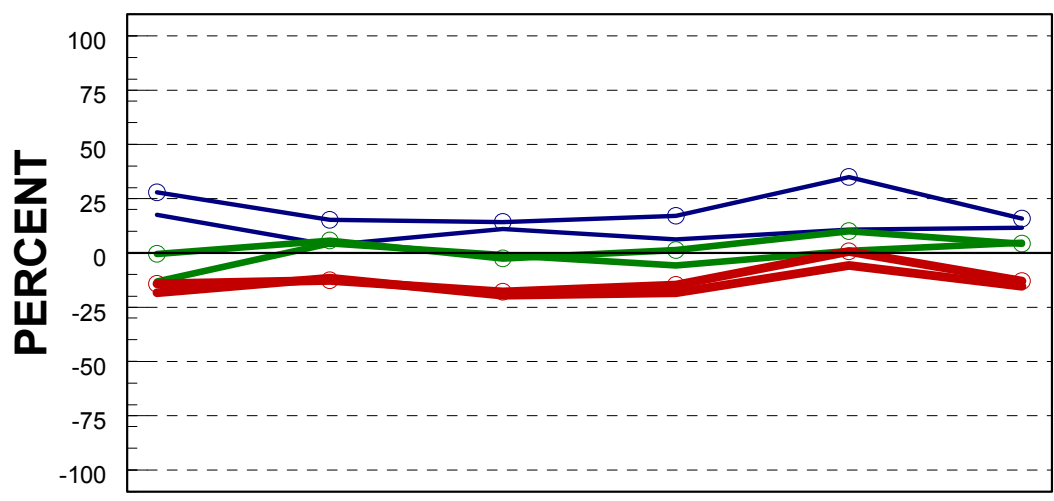

\begin{tabular}{|l|c|c|c|c|c|c|}
\hline RESISTOR DECADE & DUPONT 15 (10) & DUPONT 9 (100) & DUPONT 16 (1K) & DUPONT 17 (10K) & DUPONT 18 (100K) & DUPONT19 (1Meg) \\
\hline 25 MIL PARALLEL & 27.9 & 15.2 & 14.2 & 17.1 & 35.0 & 15.8 \\
\hline 25 MIL PERPENDICULAR - & 17.6 & 3.7 & 11.0 & 6.3 & 10.8 & 11.6 \\
\hline 50 MIL PARALLEL & $(0.5)$ & 5.7 & $(2.6)$ & 1.3 & 10.0 & 4.3 \\
\hline 50 MIL PERPENDICULAR & $(13.1)$ & 4.4 & $(1.0)$ & $(5.8)$ & 1.0 & 4.7 \\
\hline 100 MIL PARALLEL & $(14.2)$ & $(12.6)$ & $(17.9)$ & $(14.7)$ & 0.7 & $(13.0)$ \\
\hline 100 MIL PERPENDICULAR & $(18.4)$ & $(11.6)$ & $(19.5)$ & $(18.4)$ & $(5.8)$ & $(15.3)$ \\
\hline
\end{tabular}

Target dried thickness is 19 microns

Orientation Refers to Resistor Length Direction

Orientation is Relative to Squeegee Travel

Figure A-14. Resistor Geometry and Orientation 
RESISTOR GEOMETRY \& ORIENTATION

DuPont 2000 Series Printed on Alumina - 25 mil Geometries

$\%$ from Target Dried Thickness

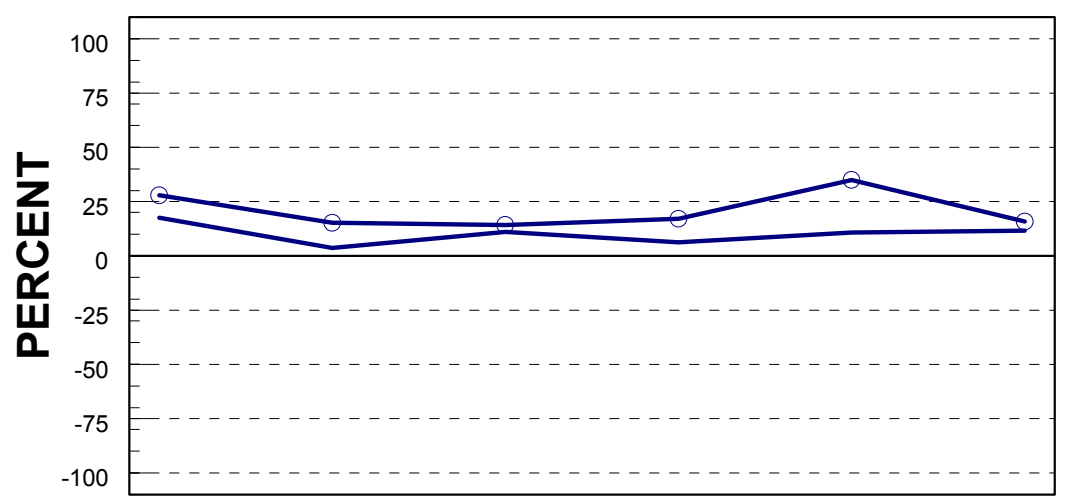

\begin{tabular}{|l|c|c|c|c|c|c|}
\hline RESISTOR DECADE & DUPONT 15 (10) & DUPONT 9 (100) & DUPONT 16 (1K) & DUPONT 17 (10K) & DUPONT 18 (100K) & DUPONT 19 (1Meg) \\
\hline 25 MIL PARALLEL & 27.9 & 15.2 & 14.2 & 17.1 & 35.0 & 15.8 \\
\hline 25 MIL PERPENDICULAR - & 17.6 & 3.7 & 11.0 & 6.3 & 10.8 & 11.6 \\
\hline
\end{tabular}

Target dried thickness is 19 microns

Orientation Refers to Resistor Length Direction

Orientation is Relative to Squeegee Travel

Figure A-15. Resistor Geometry and Orientation (25 mil)

\section{RESISTOR GEOMETRY \& ORIENTATION}

\section{DuPont 2000 Series Printed on Alumina - 50 mil Geometries}

$\%$ from Target Dried Thickness

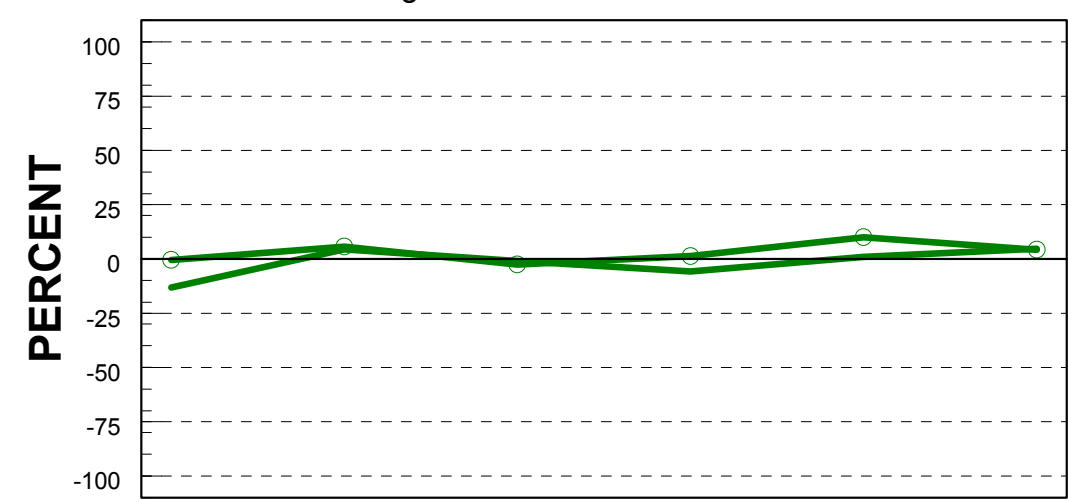

\begin{tabular}{|l|c|c|c|c|c|c|}
\hline RESISTOR DECADE & DUPONT 15(10) & DUPONT 9 (100) & DUPONT 16 (1K) & DUPONT 17 (10K) & DUPONT 18 (100K) & DUPONT 19 (1Meg) \\
\hline 50 MIL PARALLEL & $(0.5)$ & 5.7 & $(2.6)$ & 1.3 & 10.0 & 4.3 \\
\hline 50 MIL PERPENDICULAR & $(13.1)$ & 4.4 & $(1.0)$ & $(5.8)$ & 1.0 & 4.7 \\
\hline
\end{tabular}

Target dried thickness is 19 microns

Orientation Refers to Resistor Length Direction

Orientation is Relative to Squeegee Travel

Figure A-16. Resistor Geometry and Orientation (50 mil) 
RESISTOR GEOMETRY \& ORIENTATION

DuPont 2000 Series Printed on Alumina - 100 mil Gec

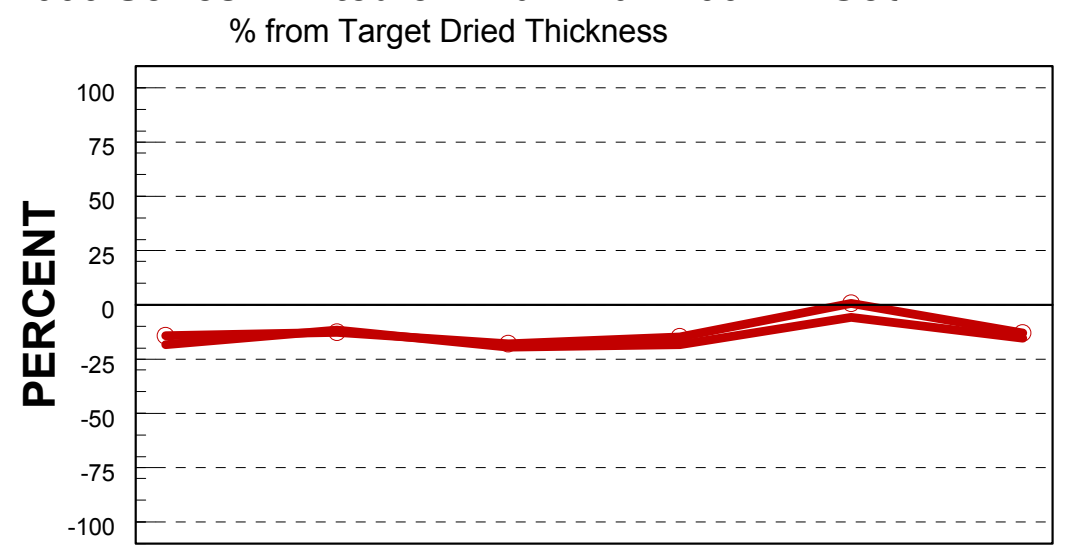

\begin{tabular}{|l|c|c|c|c|c|c|}
\hline RESISTOR DECADE & DUPONT 15(10) & DUPONT 9 (100) & DUPONT 16 (1K) & DUPONT 17 (10K) & DUPONT 18 (100K) & DUPONT 19 (1Meg) \\
\hline 100 MIL PARALLEL & $(14.2)$ & $(12.6)$ & $(17.9)$ & $(14.7)$ & 0.7 & $(13.0)$ \\
\hline 100 MIL PERPENDICULAR & $(18.4)$ & $(11.6)$ & $(19.5)$ & $(18.4)$ & $(5.8)$ & $(15.3)$ \\
\hline
\end{tabular}

Target dried thickness is 19 microns

Orientation Refers to Resistor Length Direction

Orientation is Relative to Squeegee Travel

Figure A-17. Resistor Geometry and Orientation (100 mil)

\section{THICKNESS RELATIONSHIP - DUPONT 2000 SERIES}

\section{Wet, Dried \& Fired Thicknesses}

Printed on Alumina

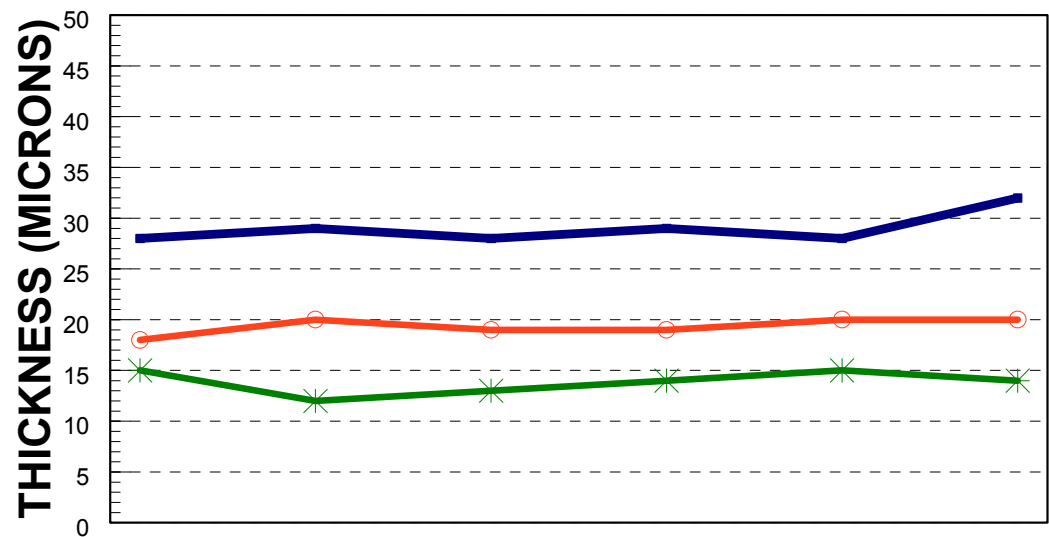

\begin{tabular}{|l|c|c|c|c|c|c|}
\hline RESISTOR DECADE & DUPONT 15 (10) & DUPONT9 (100) & DUPONT 16 (1K) & DUPONT 17 (10K) & DUPONT 18 (100K) & DUPONT 19 (1Meg) \\
\hline WET THICKNESS & 28 & 29 & 28 & 29 & 28 & 32 \\
\hline DRIED THICKNESS & 18 & 20 & 19 & 19 & 20 & 20 \\
\hline FIRED THICKNESS & 15 & 12 & 13 & 14 & 15 & 14 \\
\hline
\end{tabular}

Dried Target Thickness $=18-20$ microns

Figure A-18. Thickness Relationship 
Appendix B

COMPARATIVE DATA FOR UNTRIMMED DUPONT 1400/2000 SERIES RESISTORS PRINTED ON ALUMINA 
UNTRIMMED SHEET RESISTANCE COMPARISON - FURNACES DuPont 1400 Series Resistor Compositions

$\%$ from Nominal Resistance

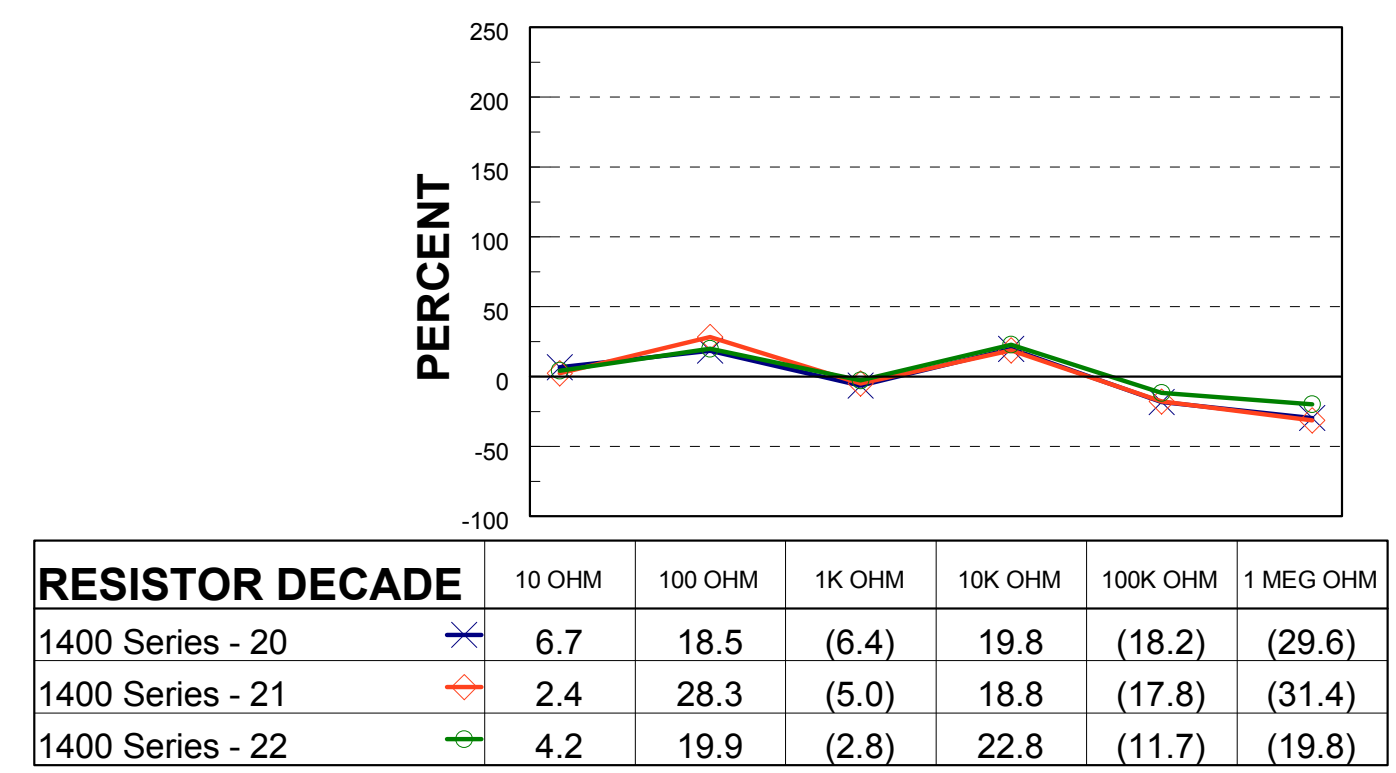

1400 Series on alumina are encapsulated

Data for 50 mil Geometries

Data based on resistors printed on alumina.

Figure B-1. Untrimmed Sheet Resistance Comparison-Furnaces (1400 Series)

\section{UNTRIMMED SHEET RESISTANCE COMPARISON - FURNACES} DuPont 2000 Series Resistor Compositions

$\%$ from Nominal Resistance

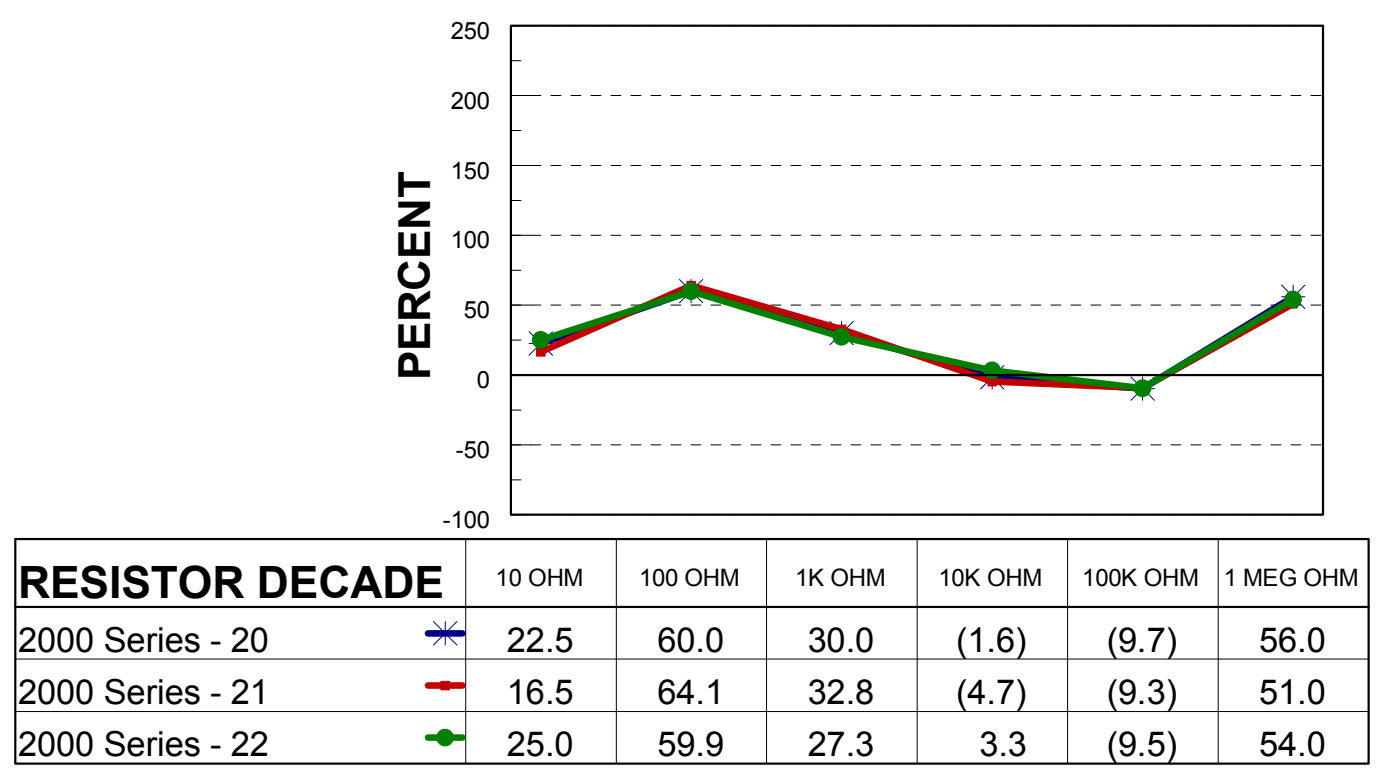

2000 Series on alumina are encapsulated

Data for 50 mil Geometries

Data based on resistors printed on alumina.

Figure B-2. Untrimmed Sheet Resistance Comparison-Furnaces (2000 Series) 
UNTRIMMED SHEET RESISTANCE COMPARISON - FURNACE 20 DuPont 1400/2000 Series Resistor Compositions

$\%$ from Nominal Resistance

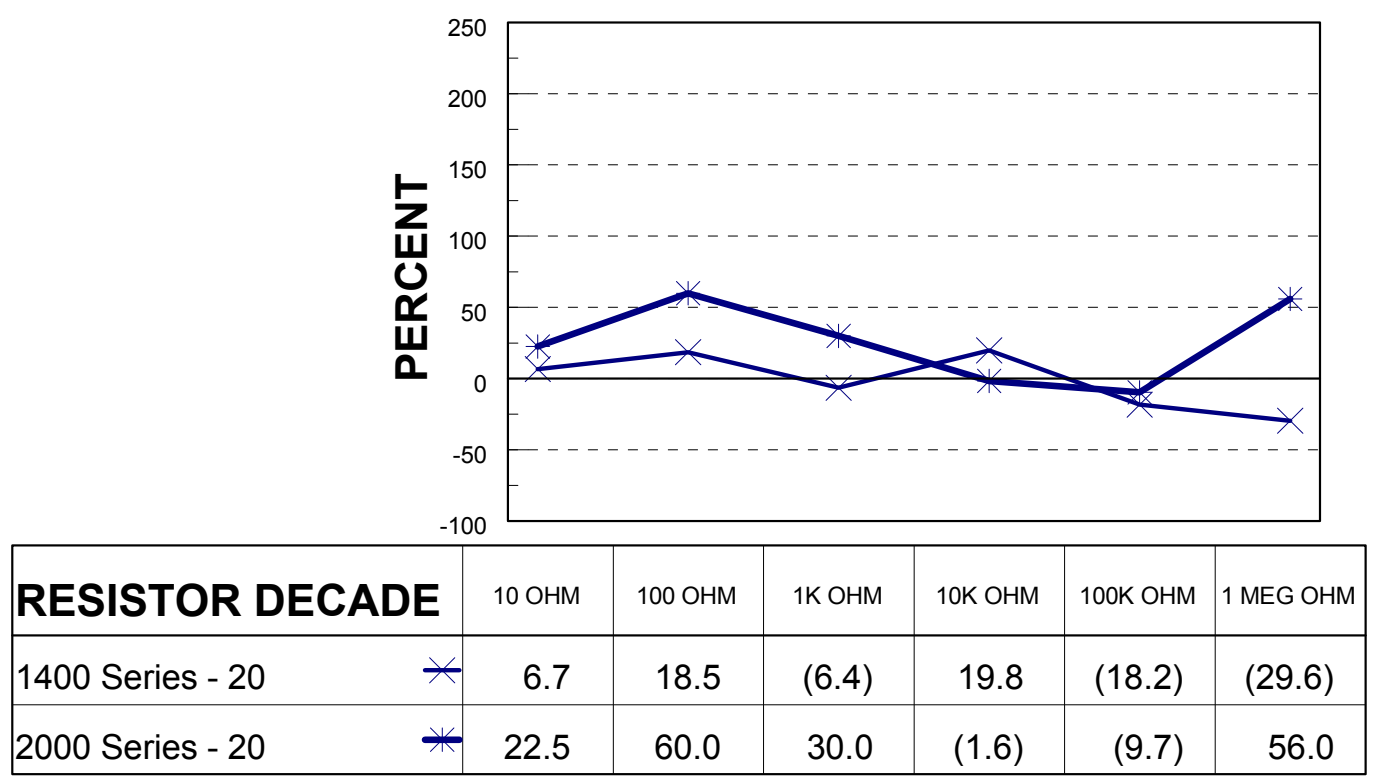

1400 Series and 2000 Series on alumina are encapsulated

Data for 50 mil Geometries

Data based on resistors printed on alumina.

Figure B-3. Untrimmed Sheet Resistance Comparison-Furnace 20

\section{UNTRIMMED SHEET RESISTANCE COMPARISON - FURNACE 21} DuPont 1400/2000 Series Resistor Compositions

$\%$ from Nominal Resistance

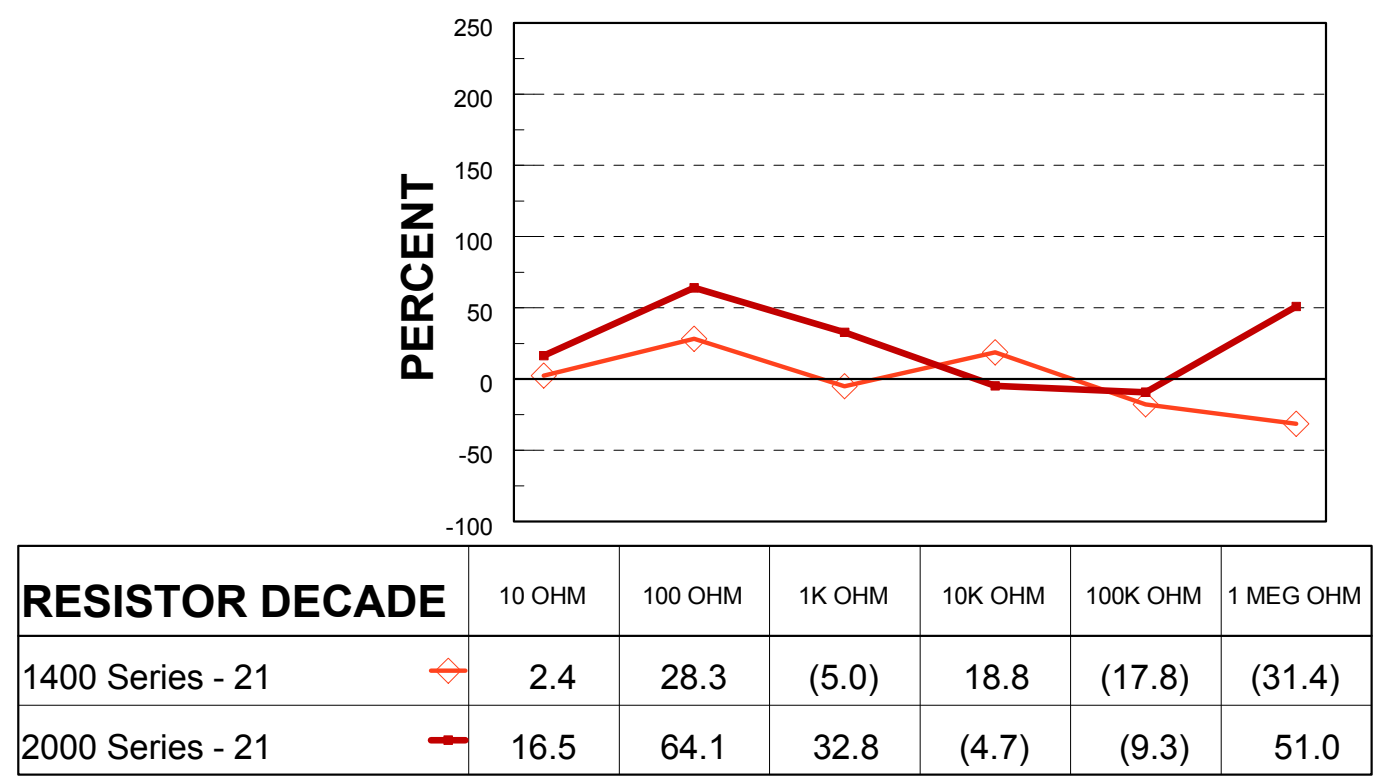

1400 Series and 2000 Series on alumina are encapsulated

Data for 50 mil Geometries

Data based on resistors printed on alumina.

Figure B-4. Untrimmed Sheet Resistance Comparison-Furnace 21 
UNTRIMMED SHEET RESISTANCE COMPARISON - FURNACE 22

DuPont 1400/2000 Series Resistor Compositions

$\%$ from Nominal Resistance

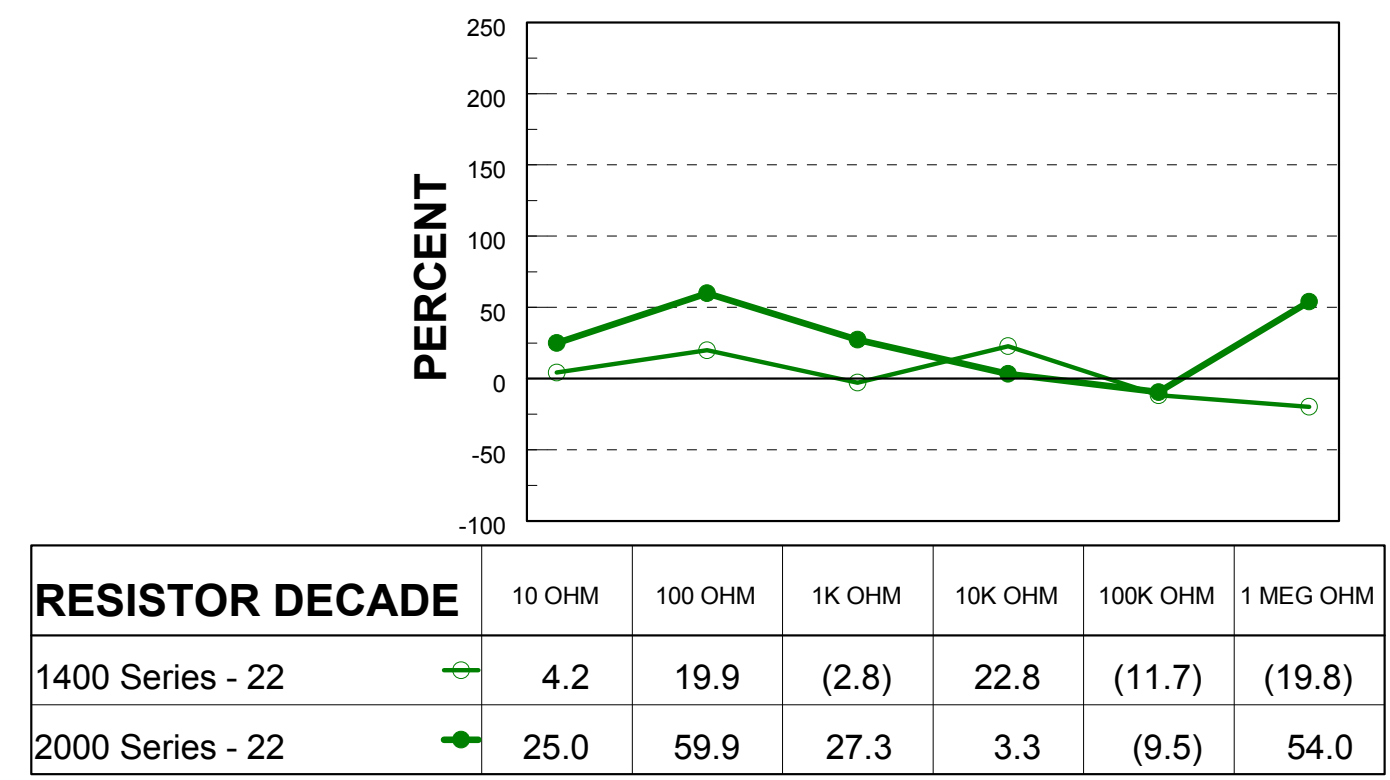

1400 Series and 2000 Series on alumina are encapsulated

Data for 50 mil Geometries

Data based on resistors printed on alumina.

Figure B-5. Untrimmed Sheet Resistance Comparison-Furnace 22 


\section{Appendix C}

\section{DUPONT 15 RESISTOR PRINTING DATA \\ ON ALUMINA \\ (10 Ohm)}




\section{FIRING PROFILE SENSITIVITY DUPONT 15 (10 OHMS PER SQUARE)}

Actual Values - Printed on Alumina

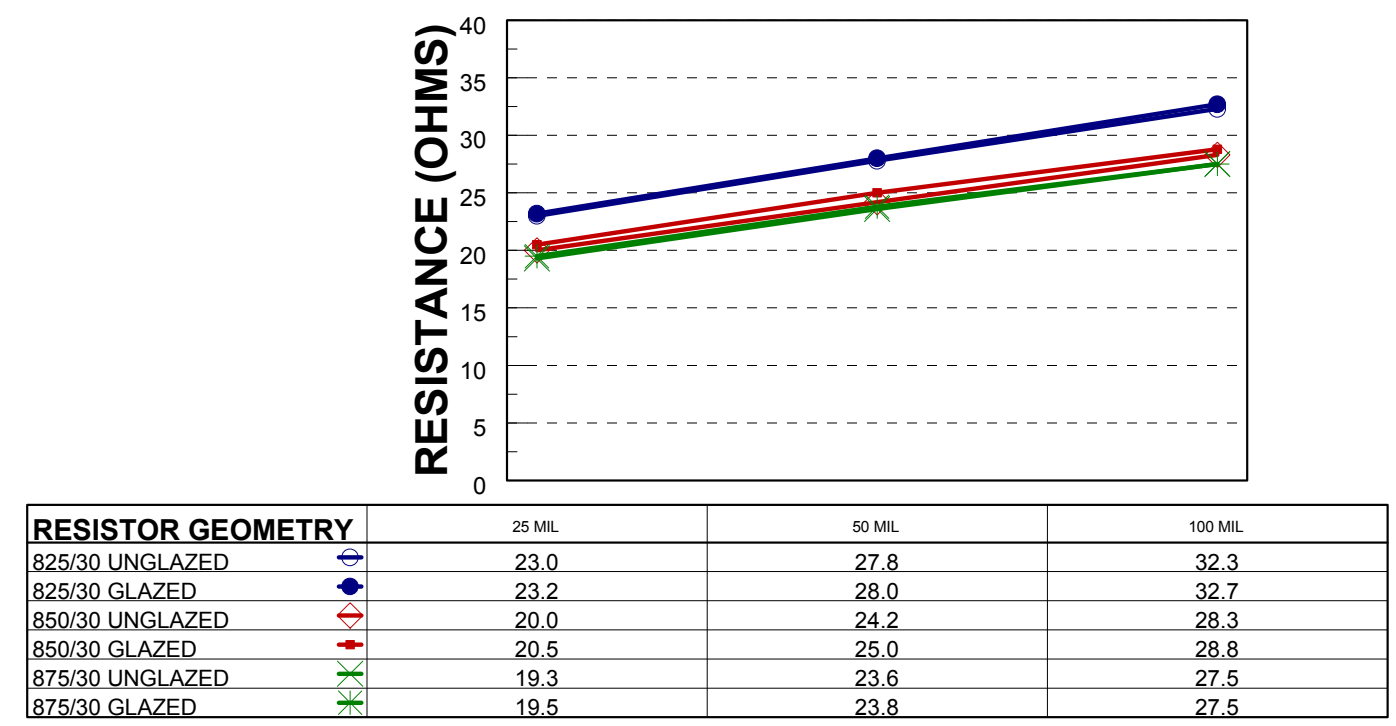

Nominal as-fired resistance is $20 \mathrm{ohms}$.

Target Dried Thickness is $18-20$ microns

Samples fired in 22

Figure C-1. Firing Profile Sensitivity (Resistance)

\section{FIRING PROFILE SENSITIVITY DUPONT 15 (10 OHMS PER SQUARE)}

Percent from Nominal Values - Printed on Alumina

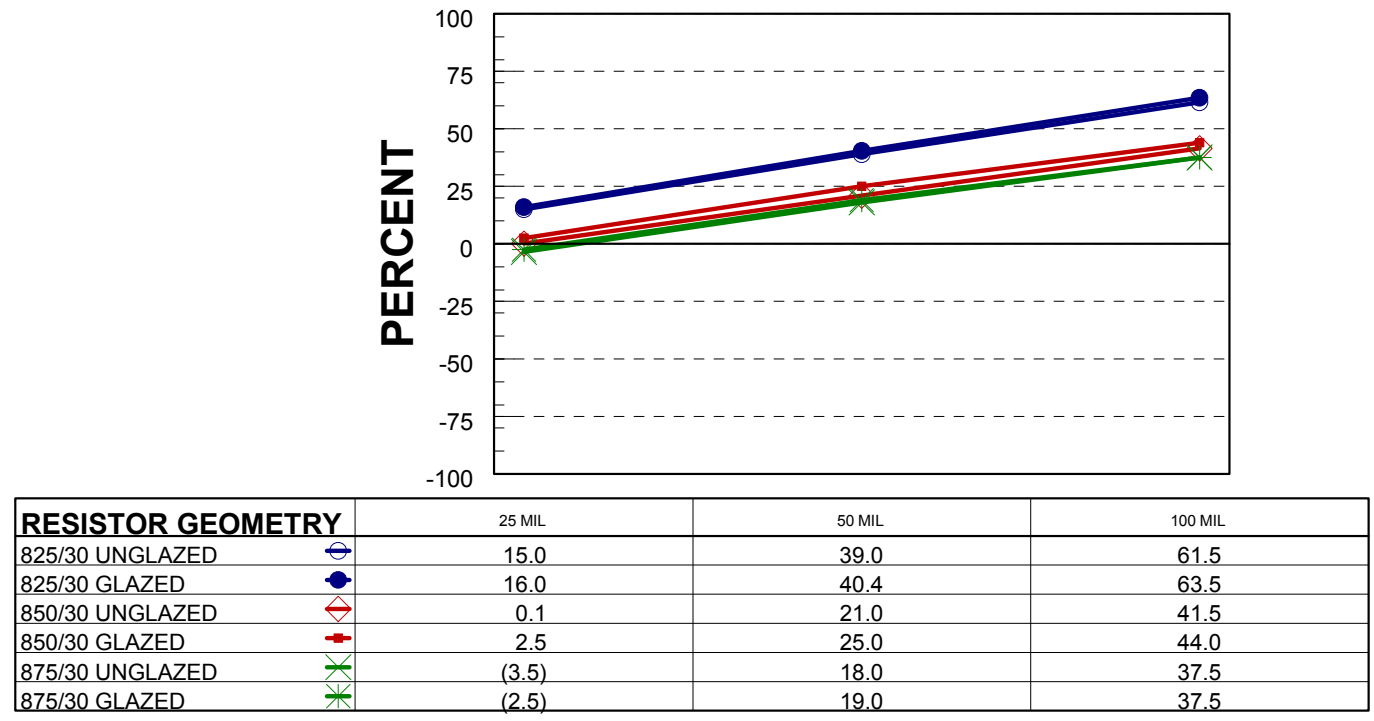

Nominal as-fired resistance is $20 \mathrm{ohms}$.

Target Dried Thickness is $18-20$ microns

Samples fired in 22

Figure C-2. Firing Profile Sensitivity (Percent) 


\section{FURNACE SENSITIVITY \\ DUPONT 15 (10 OHMS PER SQUARE)}

Actual Values - Printed on Alumina

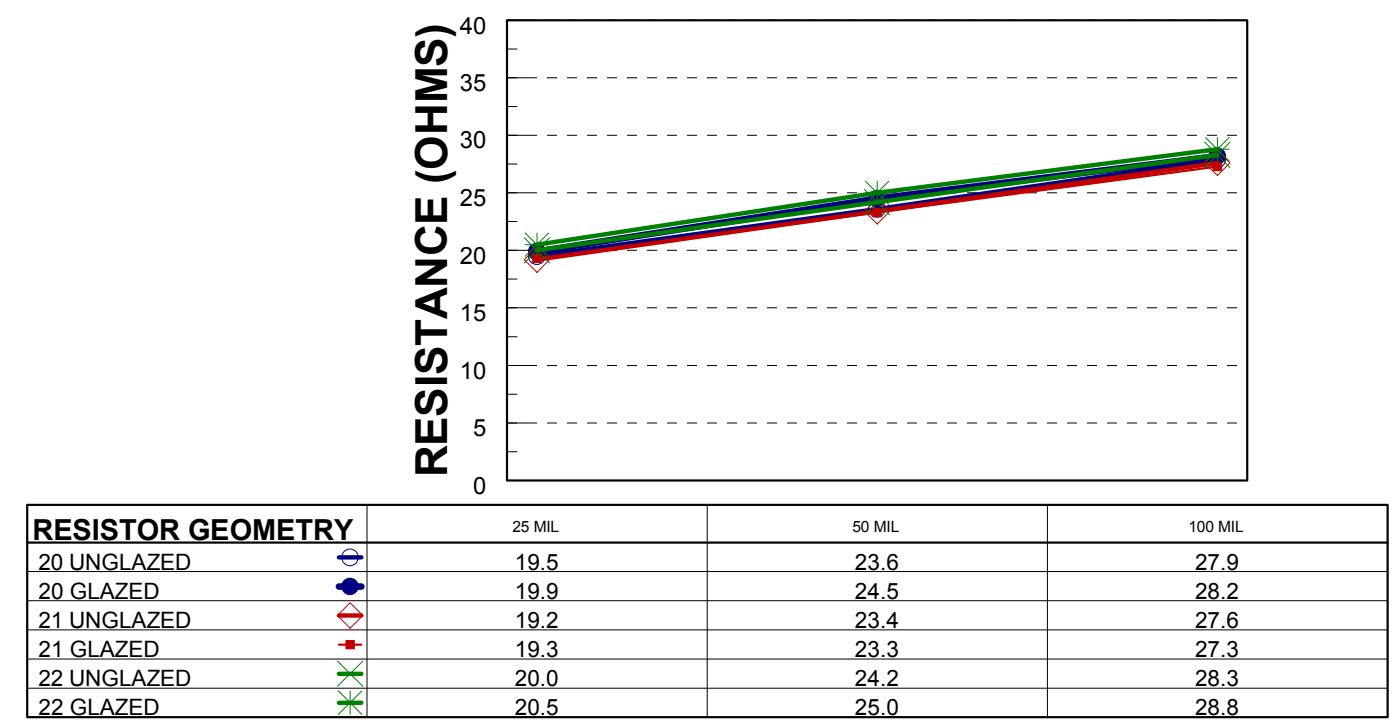

Nominal as-fired resistance is 20 ohms.

Target Dried Thickness is $18-20$ microns

Samples fired with $850 / 30$ profile

Figure C-3. Furnace Sensitivity (Resistance, $10 \mathrm{ohm}$ )

\section{FURNACE SENSITIVITY}

DUPONT 15 (10 OHMS PER SQUARE)

Percent from Nominal Values - Printed on Alumina

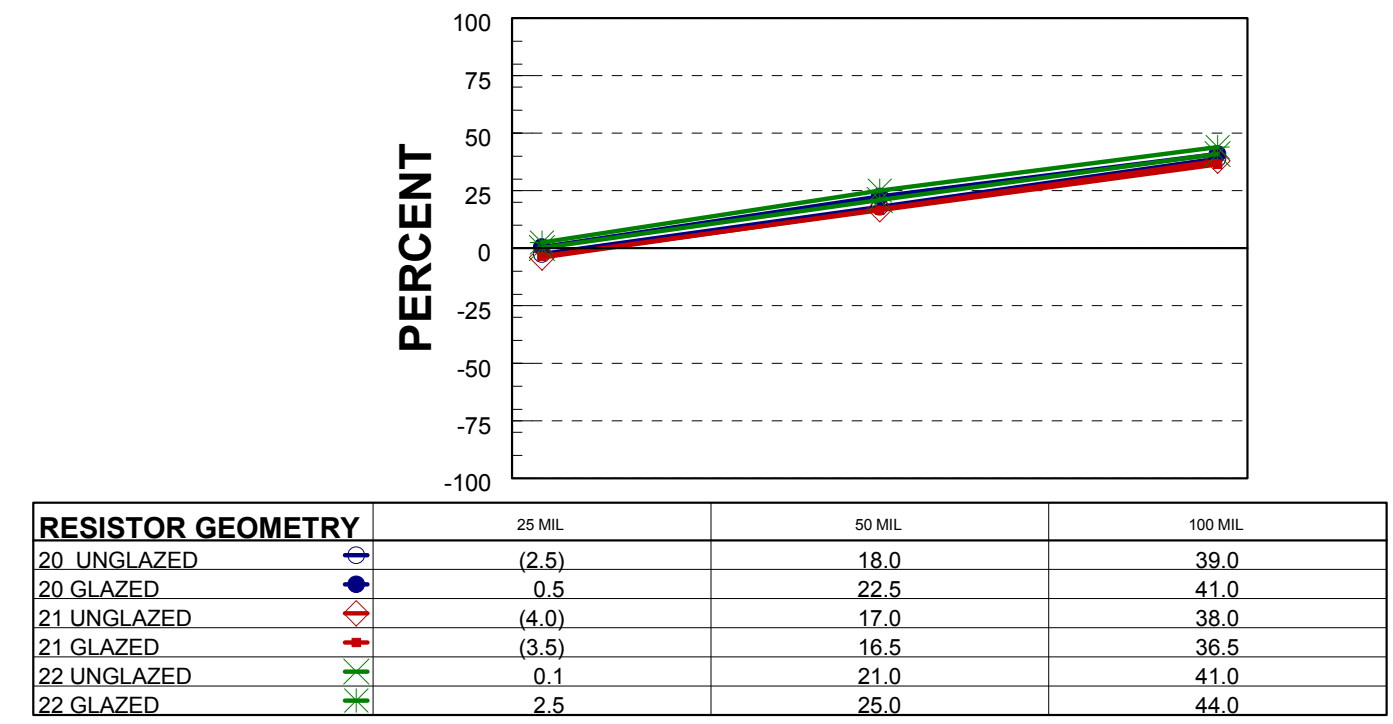

Nominal as-fired resistance is $20 \mathrm{ohms}$.

Target Dried Thickness is $18-20$ microns

Samples fired with $850 / 30$ profile

Figure C-4. Furnace Sensitivity (Percent, 10 ohm) 


\section{NORMALIZED SHEET RESISTANCE DUPONT 15 (10 OHMS PER SQUARE)}

Actual Values - Printed on Alumina

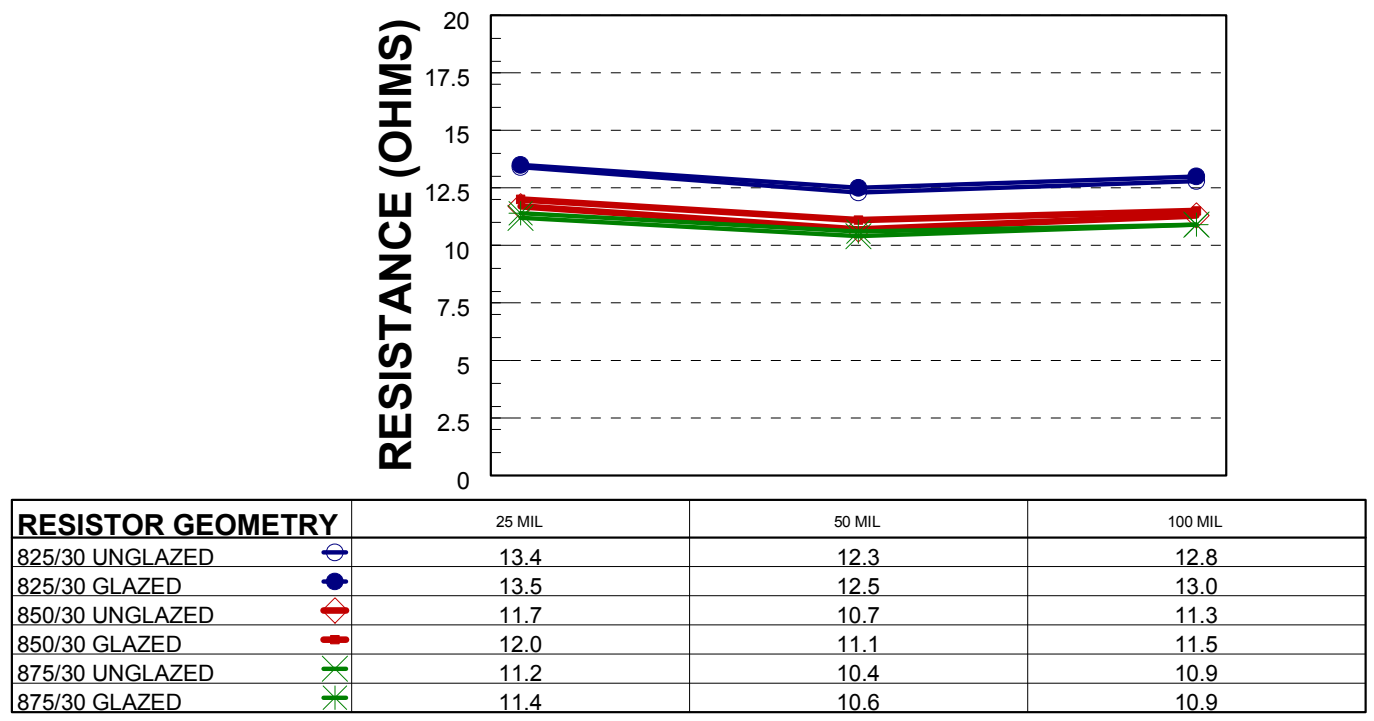

Nominal normalized resistance is $10 \mathrm{ohms}$

Target Dried Thickness is $18-20$ microns

Samples fired in 22

Figure C-5. Normalized Sheet Resistance

\section{NORMALIZED SHEET RESISTANCE}

\section{DUPONT 15 (10 OHMS PER SQUARE)}

Percent from Nominal Normalized Resistance - Printed on Alumina

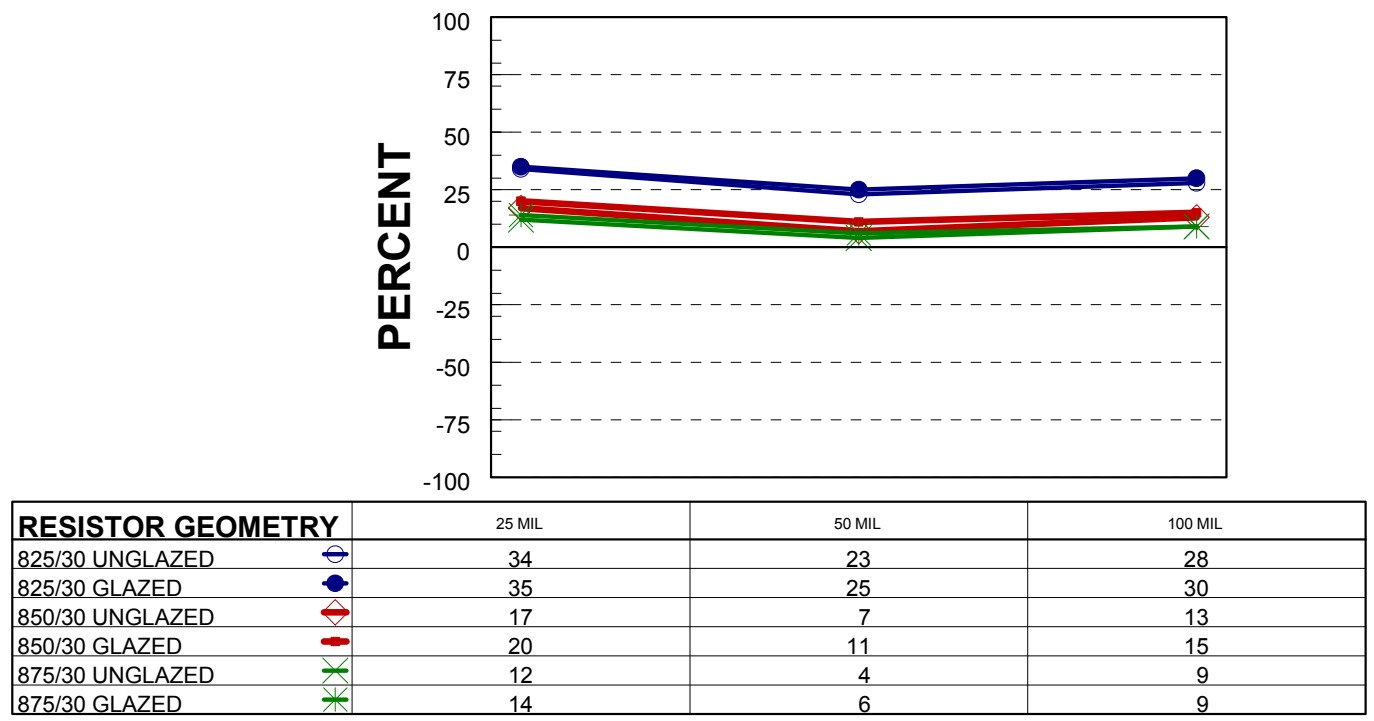

Nominal normalized resistance is $10 \mathrm{ohms}$

Target Dried Thickness is $18-20$ microns

Samples fired in 22

Figure C-6. Normalized Sheet Resistance (Percent) 


\section{NORMALIZED SHEET RESISTANCE DUPONT 15 (10 OHMS PER SQUARE)}

Actual Values - Printed on Alumina

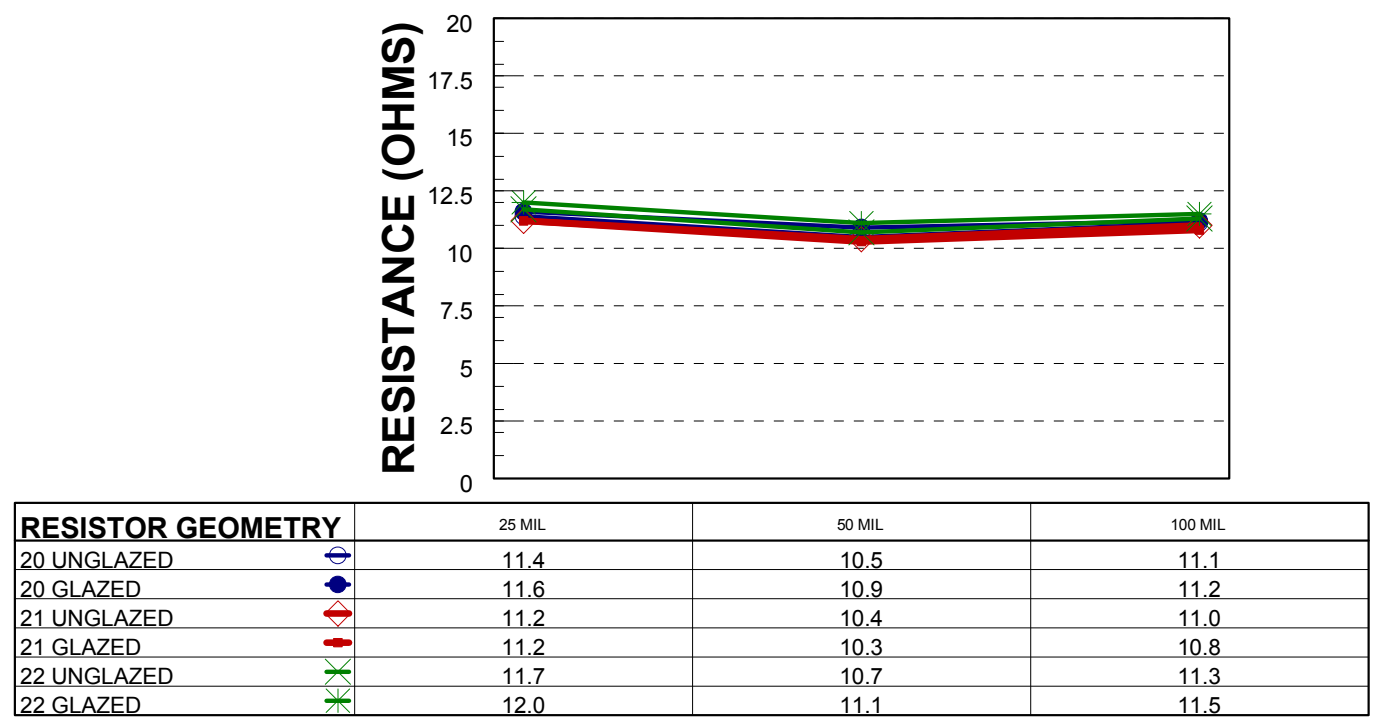

Nominal normalized resistance is $10 \mathrm{ohms}$.

Target Dried Thickness is $18-20$ microns

Samples fired with $850 / 30$ profile

Figure C-7. Normalized Sheet Resistance (Resistance, $10 \mathrm{ohm}$ )

\section{NORMALIZED SHEET RESISTANCE}

\section{DUPONT 15 (10 OHMS PER SQUARE)}

Percent from Nominal Normalized Resistance - Printed on Alumina

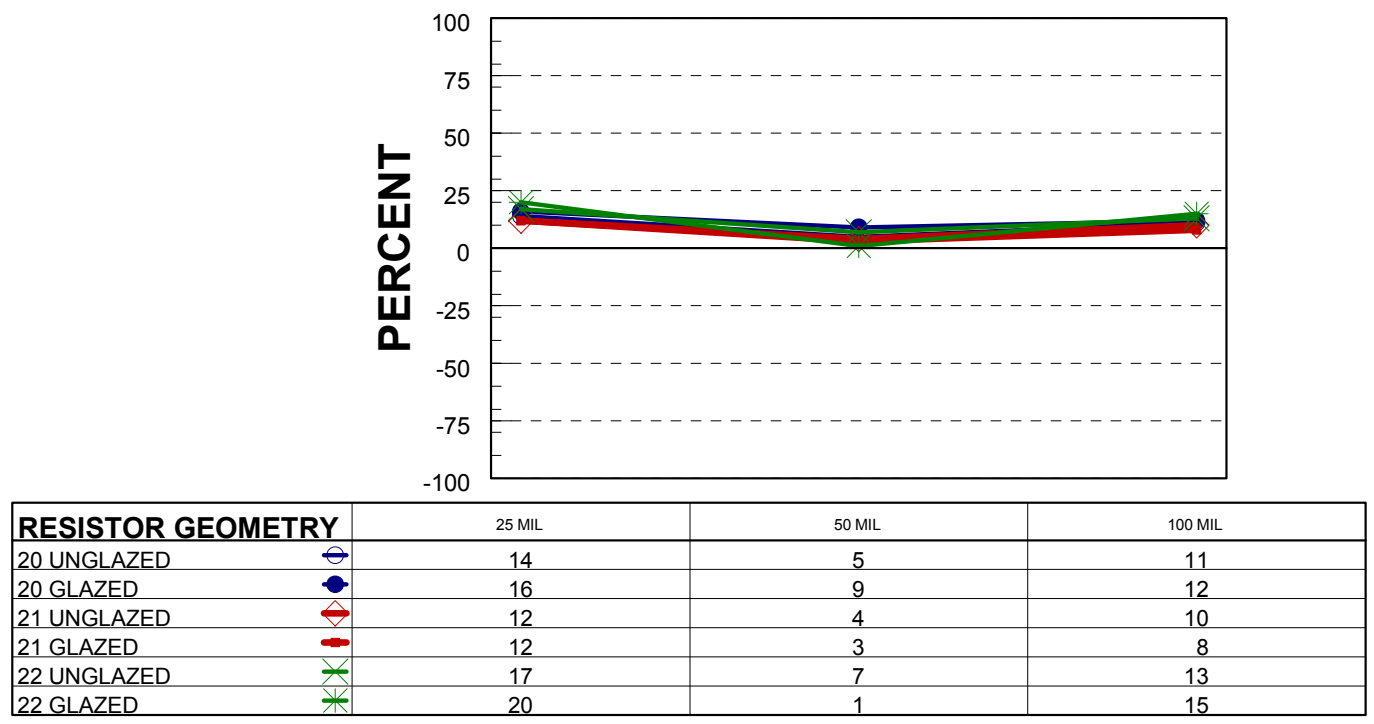

Nominal normalized resistance is $10 \mathrm{ohms}$.

Target Dried Thickness is $18-20$ microns

Samples fired in 22

Figure C-8. Normalized Sheet Resistance (Percent, 10 ohm) 


\section{THICKNESS \& RESISITIVITY COMPARISON}

DUPONT 15 (10 OHMS PER SQUARE)

Actual Values - Printed on Alumina

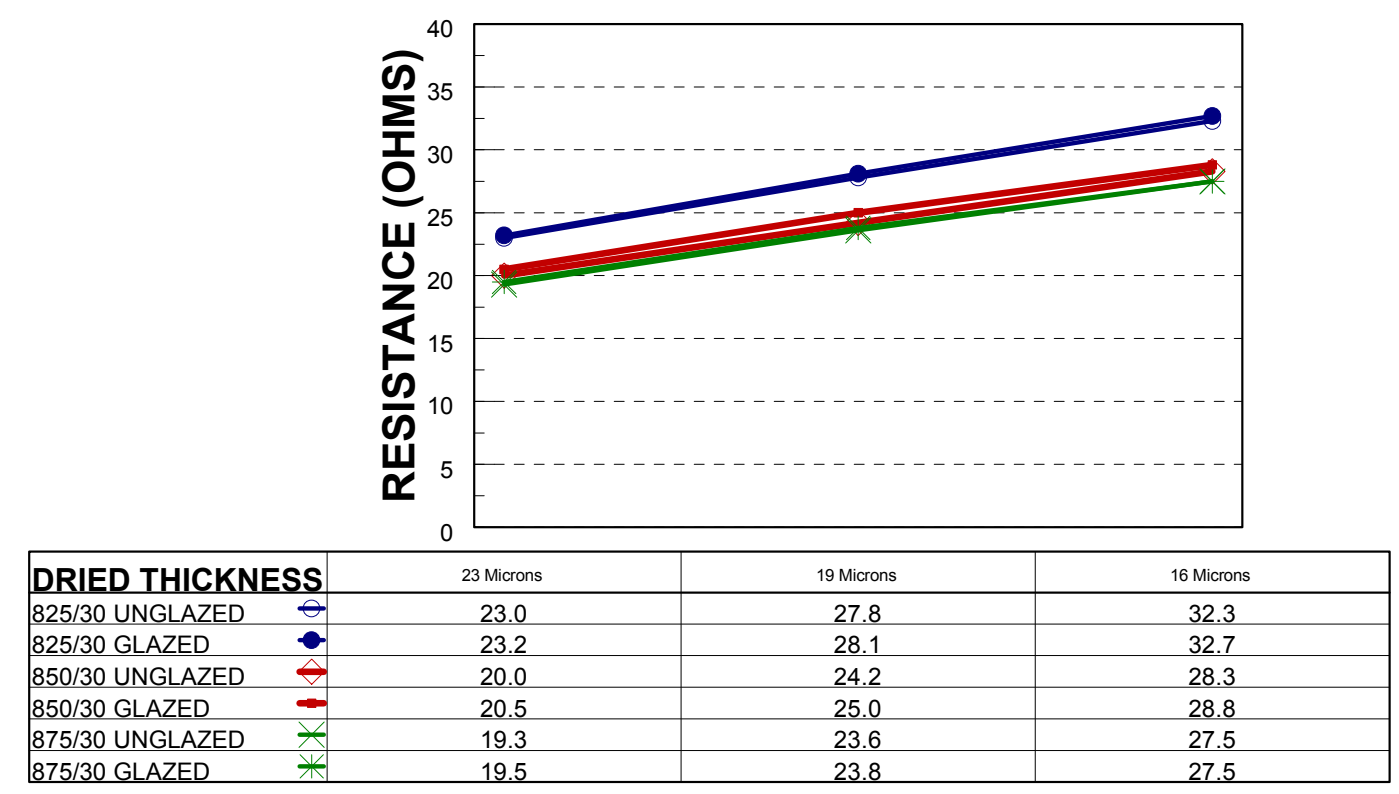

Target Dried Thickness is $18-20$ microns

Figure C-9. Thickness and Resistivity Comparison

\section{THICKNESS \& RESISITIVITY COMPARISON} DUPONT 15 (10 OHMS PER SQUARE)

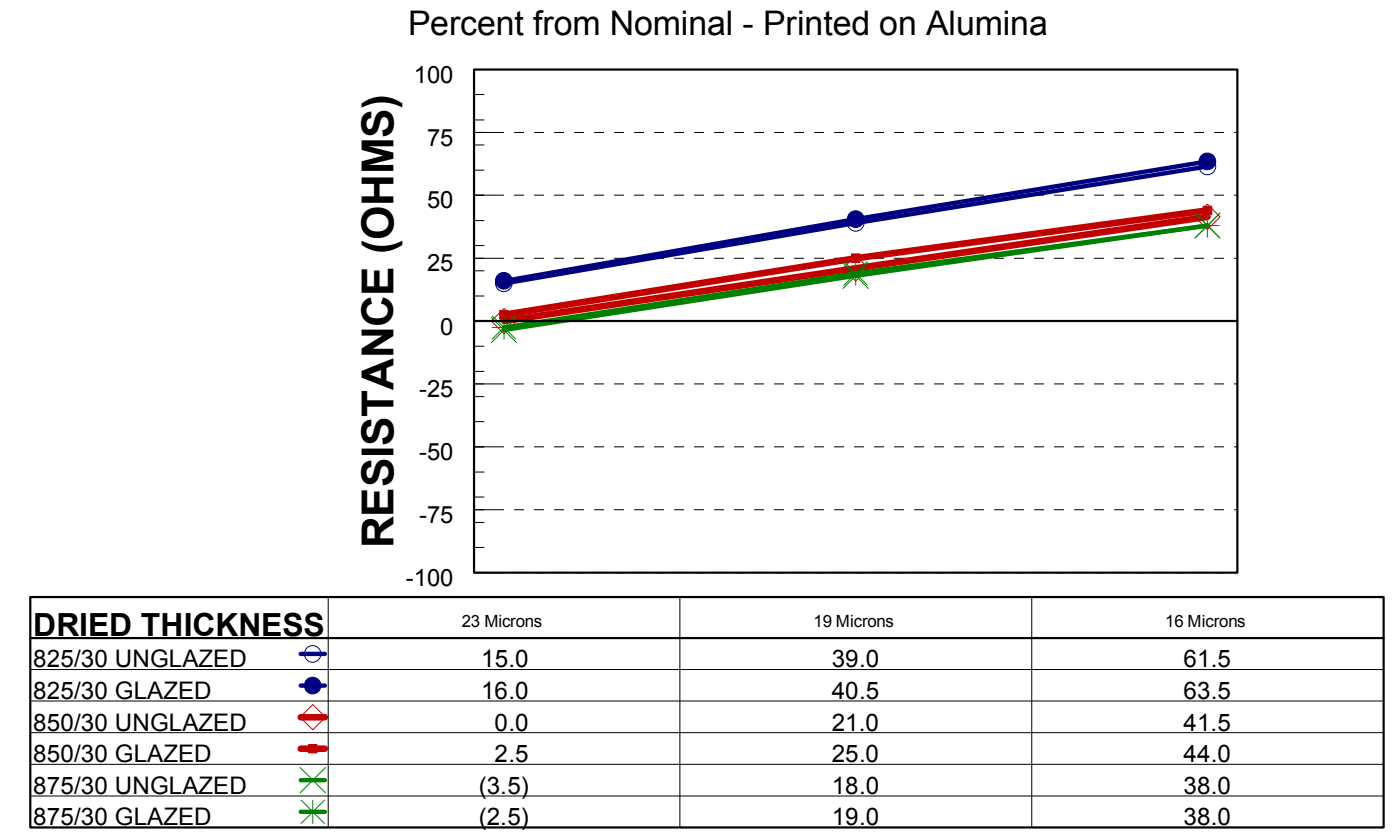

Target Dried Thickness is $18-20$ microns

Figure C-10. Thickness and Resistivity Comparison (10 ohm) 


\section{THICKNESS RELATIONSHIP \\ DUPONT 15 (10 OHMS PER SQUARE) \\ Printed on Alumina}

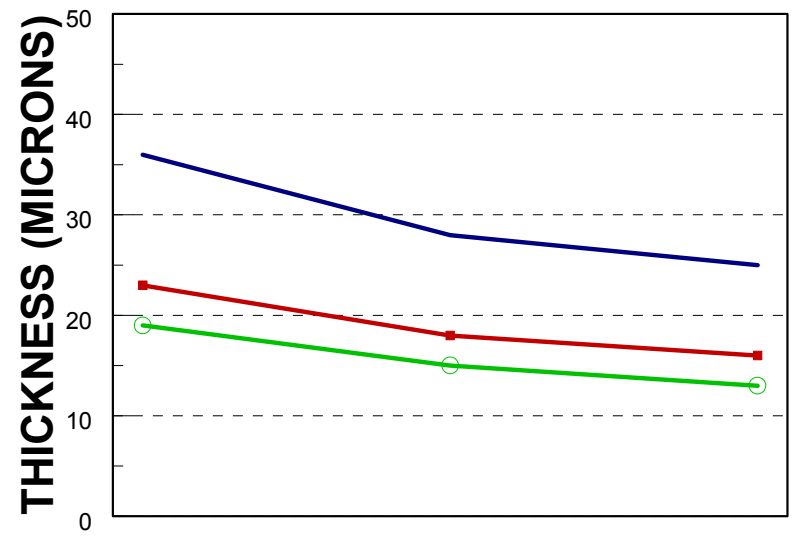

\begin{tabular}{|c|c|c|c|}
\hline GEOMETRY & $25 \mathrm{MIL}$ & $50 \mathrm{MIL}$ & $100 \mathrm{MIL}$ \\
\hline WET THICKNESS - & 36 & 28 & 25 \\
\hline DRIED THICKNESS - & 23 & 18 & 16 \\
\hline FIRED THICKNESS - & 19 & 15 & 13 \\
\hline
\end{tabular}

Target Dried Thickness is $18-20$ microns

Figure C-11. Thickness Relationship 


\section{Appendix D}

\section{DUPONT 9 RESISTOR PRINTING DATA \\ ON ALUMINA \\ (100 Ohm)}




\section{FIRING PROFILE SENSITIVITY DUPONT 2021(100 OHMS PER SQUARE)}

Actual Values - Printed on Alumina

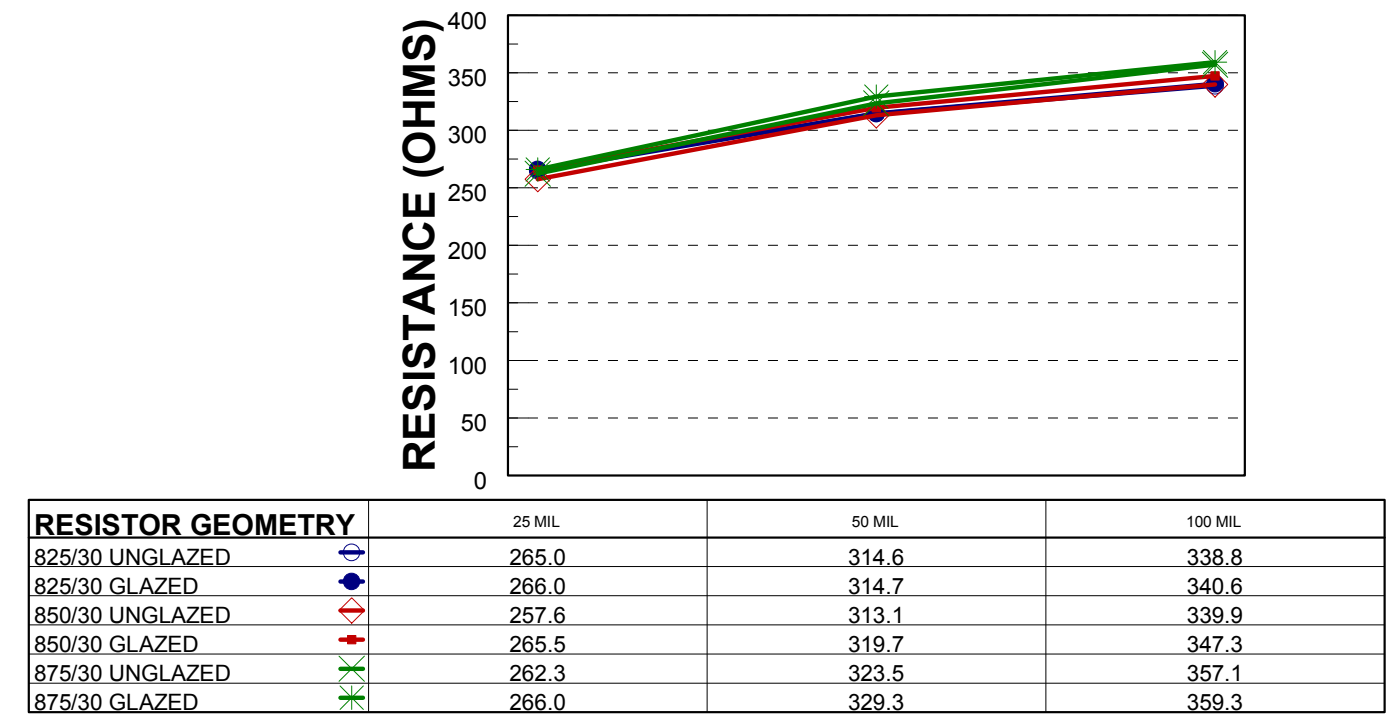

Nominal as-fired resistance is $200 \mathrm{ohms}$.

Target Dried Thickness is $18-20$ microns

Samples fired in 22

Figure D-1. Firing Profile Sensitivity (Resistance, 100 ohm)

\section{FIRING PROFILE SENSITIVITY}

DUPONT 9 (100 OHMS PER SQUARE)

Percent from Nominal Values - Printed on Alumina

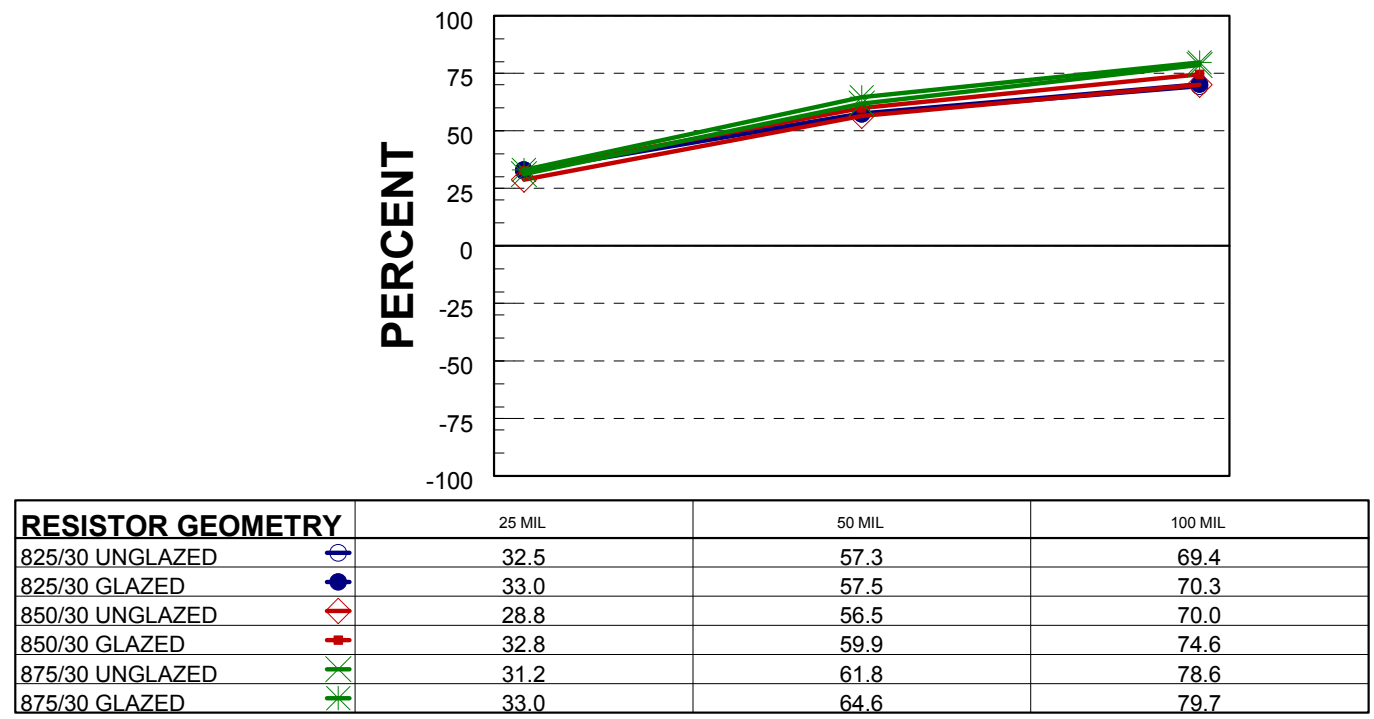

Nominal as-fired resistance is $200 \mathrm{ohms}$.

Target Dried Thickness is $18-20$ microns

Samples fired in 22

Figure D-2. Firing Profile Sensitivity (Percent, $100 \mathrm{ohm}$ ) 


\section{FURNACE SENSITIVITY \\ DUPONT 9 (100 OHMS PER SQUARE)}

Actual Values - Printed on Alumina

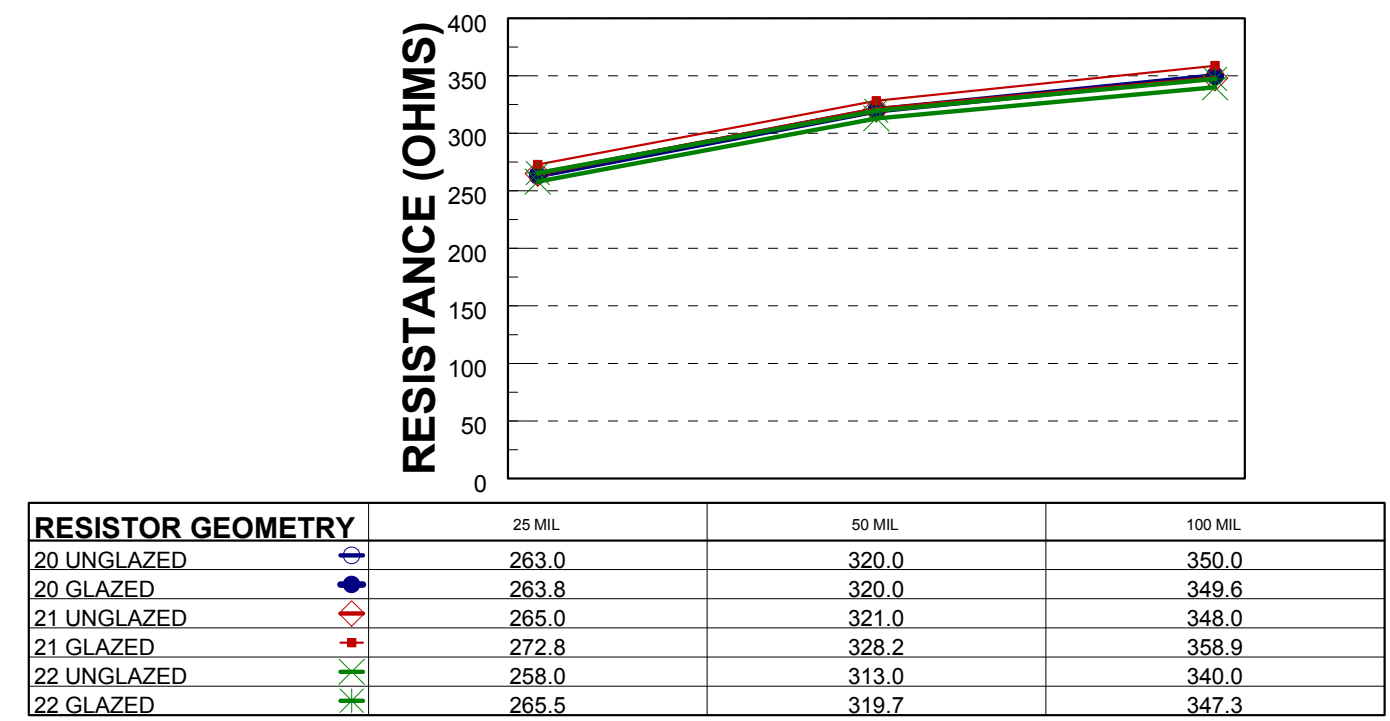

Nominal as-fired resistance is $200 \mathrm{ohms}$.

Target Dried Thickness is $18-20$ microns

Samples fired with $850 / 30$ profile

Figure D-3. Furnace Sensitivity (Resistance, 100 ohm)

\section{FURNACE SENSITIVITY \\ DUPONT 9 (100 OHMS PER SQUARE)}

Percent from Nominal Values - Printed on Alumina

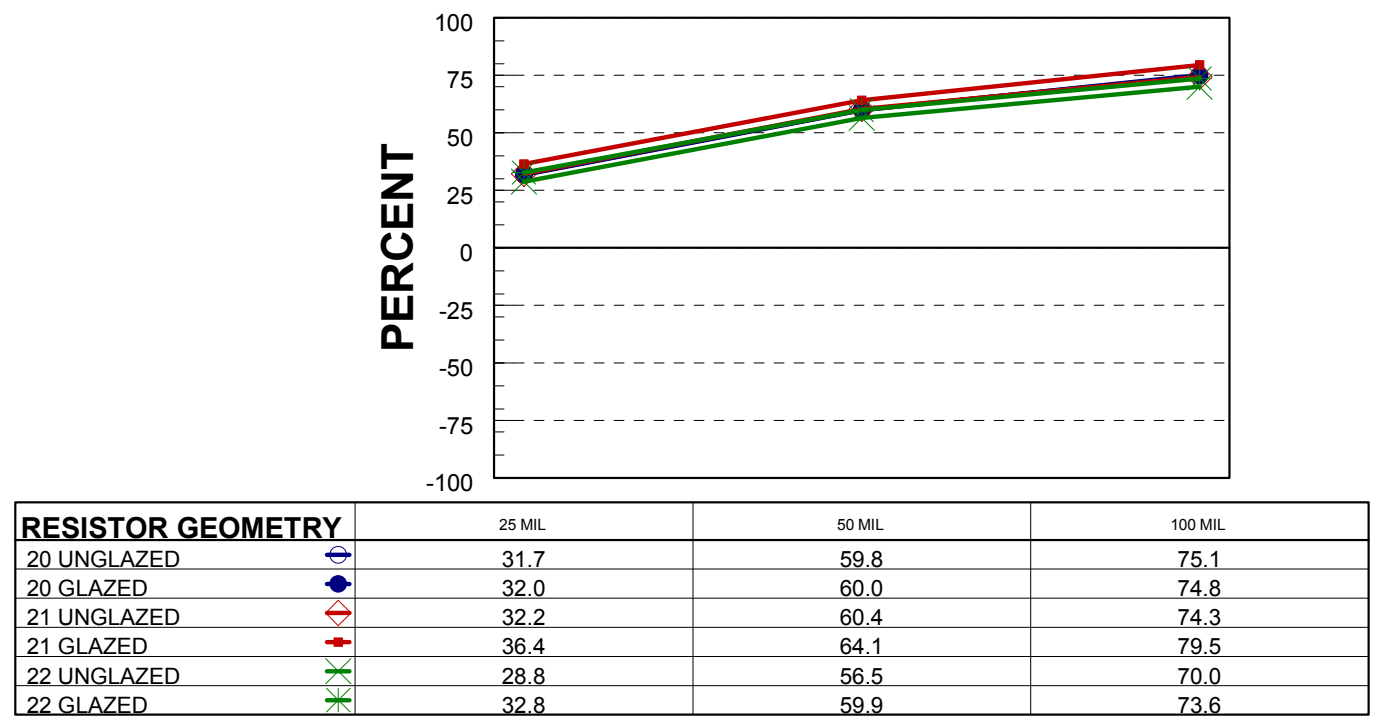

Nominal as-fired resistance is $200 \mathrm{ohms}$.

Target Dried Thickness is $18-20$ microns

Samples fired with $850 / 30$ profile

Figure D-4. Furnace Sensitivity (Percent, 100 ohm) 


\section{NORMALIZED SHEET RESISTANCE DUPONT 9 (100 OHMS PER SQUARE)}

Actual Values - Printed on Alumina

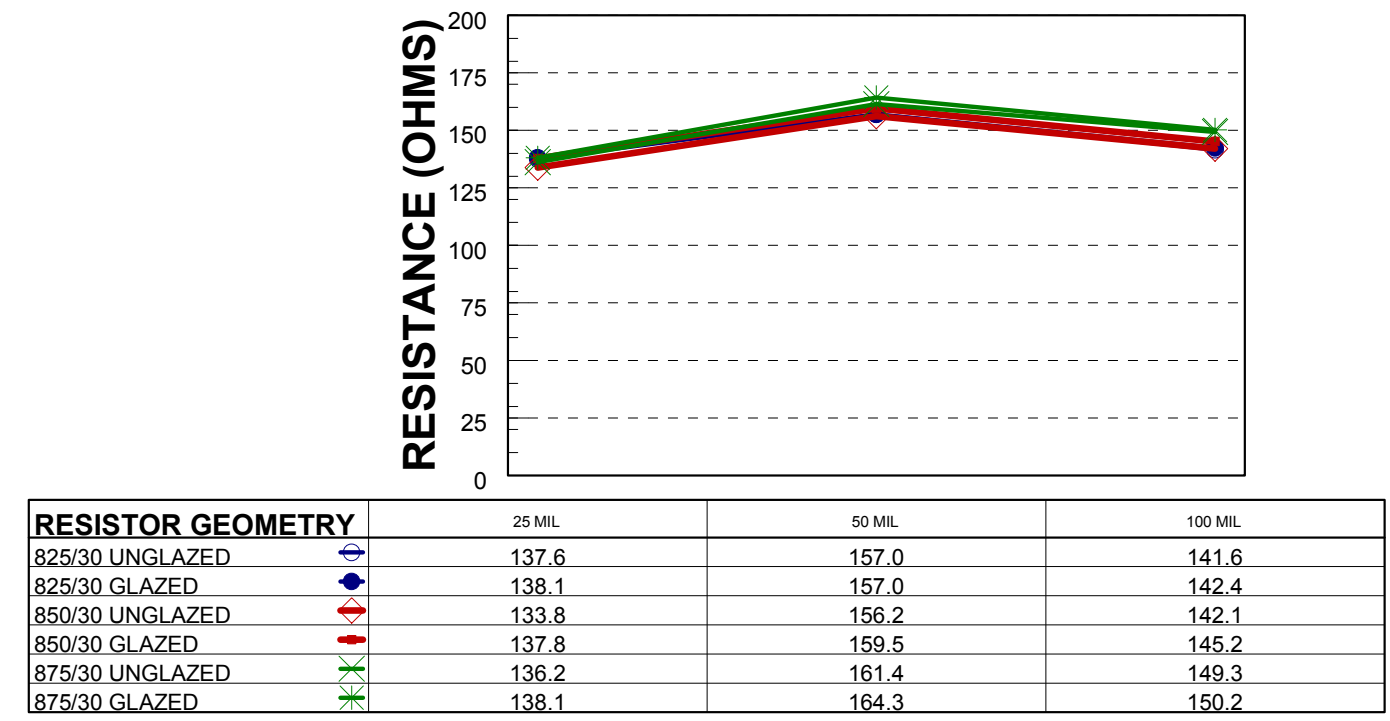

Nominal normalized resistance is 100 ohms.

Target Dried Thickness is $18-20$ microns

Samples fired in 22

Figure D-5. Normalized Sheet Resistance (Resistance, 100 ohm)

\section{NORMALIZED SHEET RESISTANCE DUPONT 9 (100 OHMS PER SQUARE)}

Percent from Nominal Normalized Resistance - Printed on Alumina

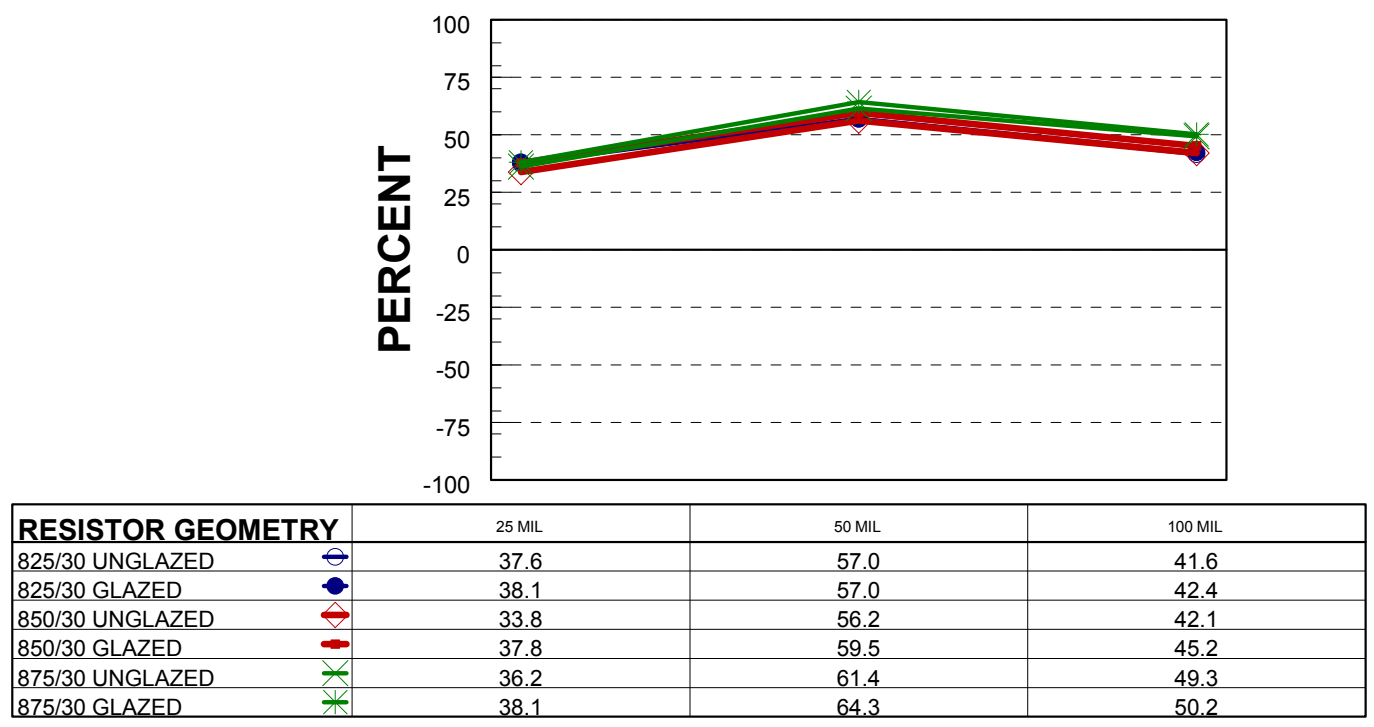

Nominal normalized resistance is 100 ohms.

Target Dried Thickness is $18-20$ microns

Samples fired in 22

Figure D-6. Normalized Sheet Resistance (Percent, 100 ohm) 


\section{NORMALIZED SHEET RESISTANCE DUPONT 9 (100 OHMS PER SQUARE)}

Actual Values - Printed on Alumina

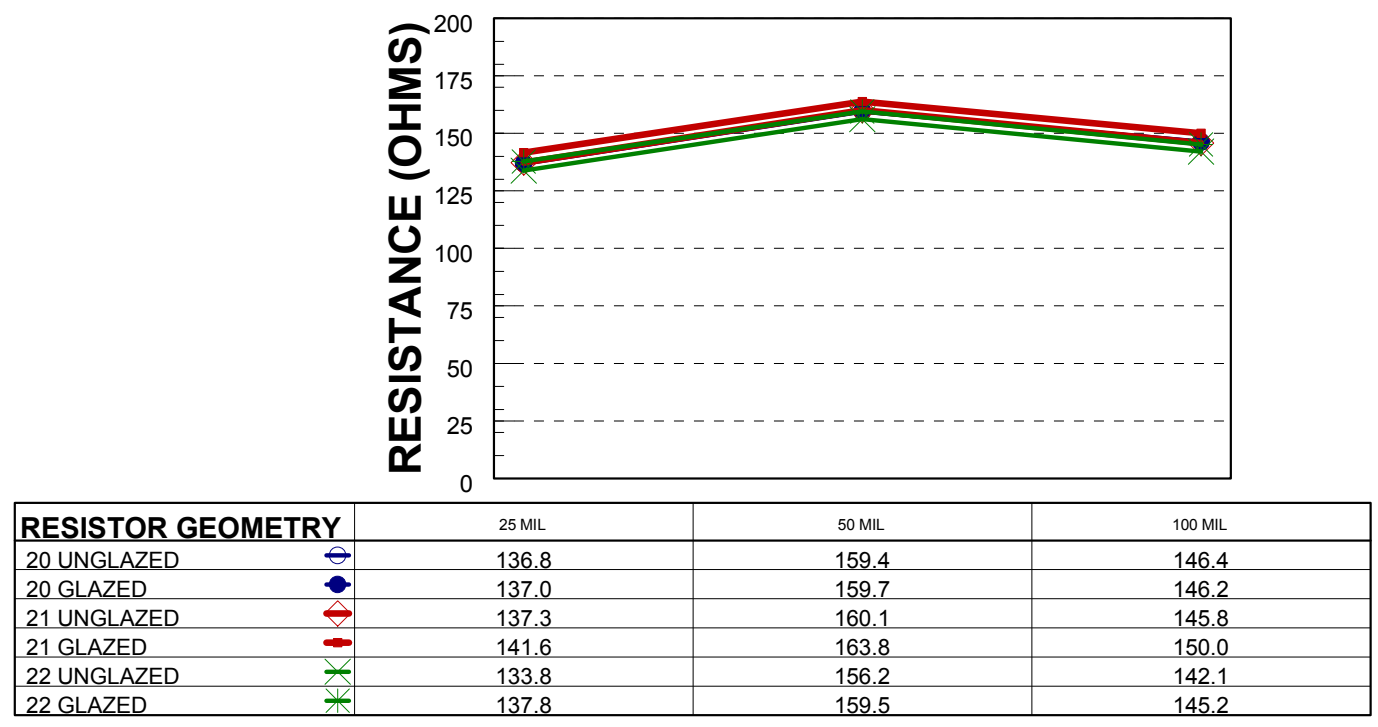

Nominal normalized resistance is 100 ohms.

Target Dried Thickness is $18-20$ microns

Samples fired with $850 / 30$ profile

Figure D-7. Normalized Sheet Resistance (Resistance, $100 \mathrm{ohm}$ )

\section{NORMALIZED SHEET RESISTANCE DUPONT 9 (100 OHMS PER SQUARE)}

Percent from Nominal Normalized Resistance - Printed on Alumina

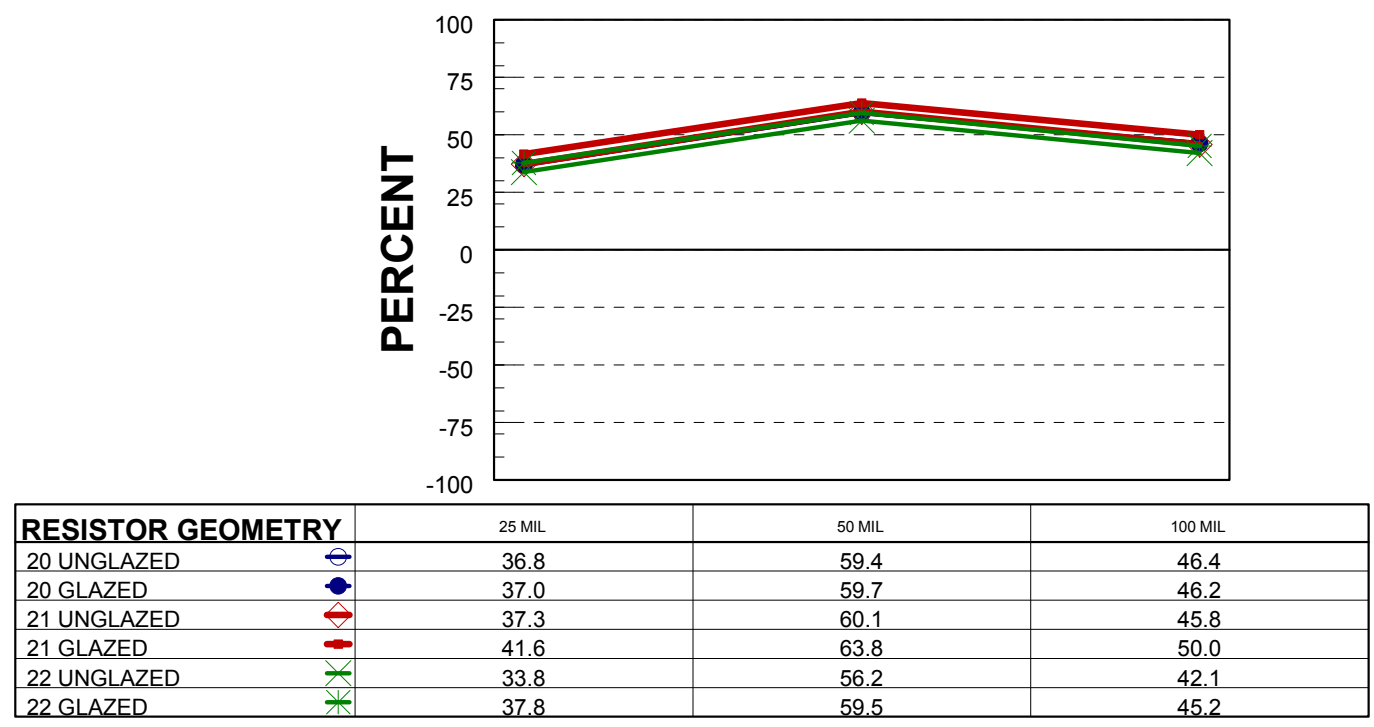

Nominal normalized resistance is 100 ohms.

Target Dried Thickness is $18-20$ microns

Samples fired in 22

Figure D-8. Normalized Sheet Resistance (Percent, 100 ohm) 


\section{THICKNESS \& RESISITIVITY COMPARISON}

DUPONT 9 (100 OHMS PER SQUARE)

Actual Values - Printed on Alumina

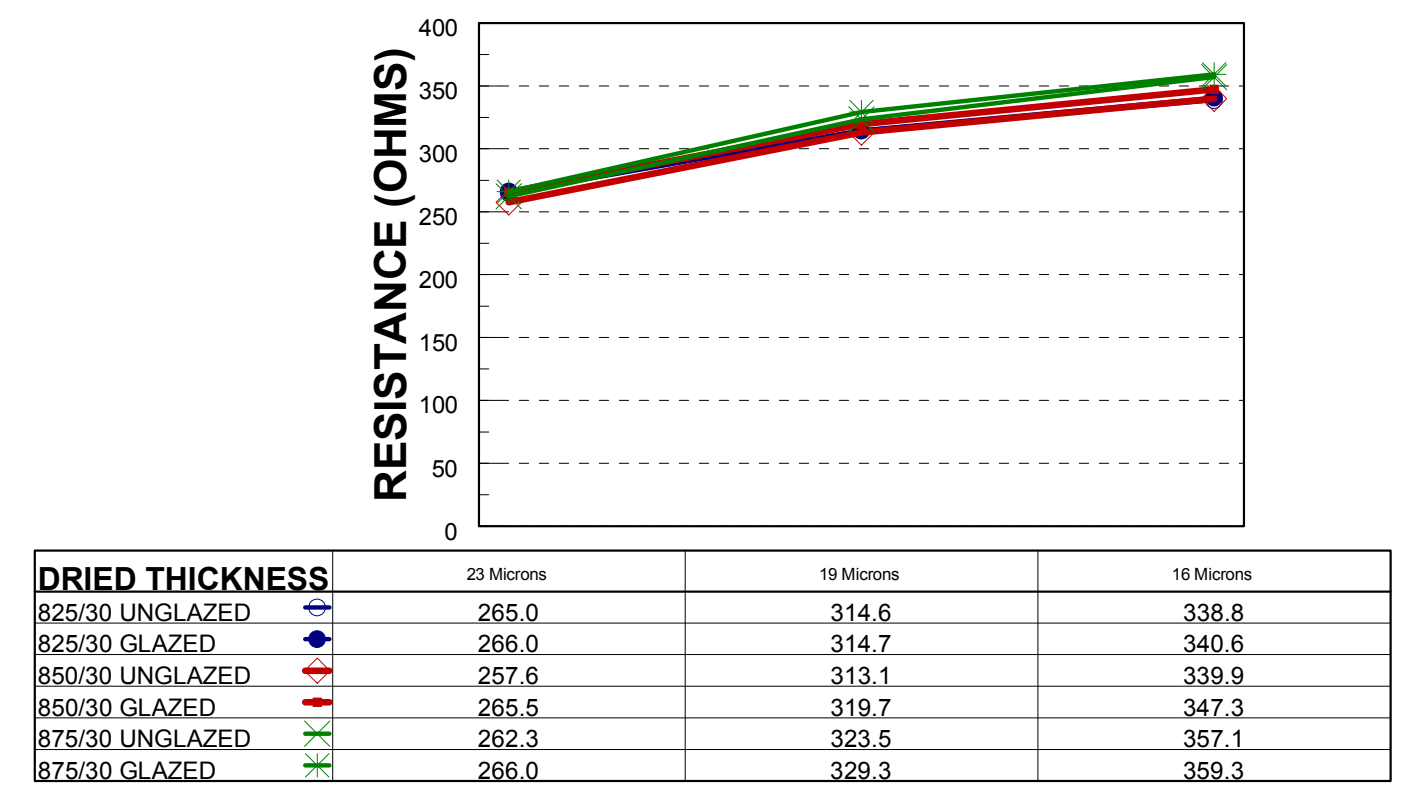

Target Dried Thickness is $18-20$ microns

Figure D-9. Thickness and Resistivity Comparison (Resistance, $100 \mathrm{ohm}$ )

\section{THICKNESS \& RESISITIVITY COMPARISON} DUPONT 9 (100 OHMS PER SQUARE)

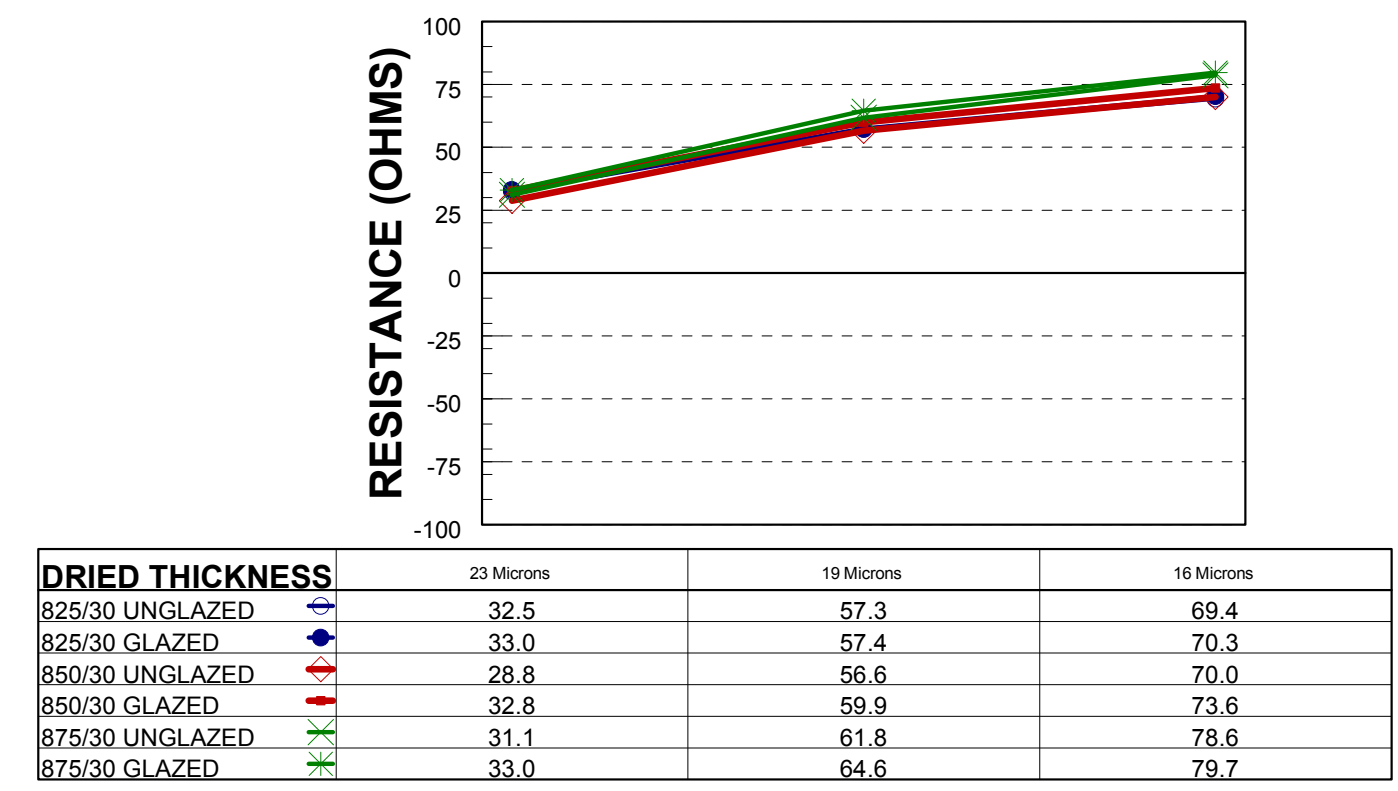

Target Dried Thickness is $18-20$ microns

Figure D-10. Thickness and Resistivity Comparison (Resistance, $100 \mathrm{ohm}$ ) 


\section{THICKNESS RELATIONSHIP DUPONT 9 (100 OHMS PER SQUARE)}

Printed on Alumina

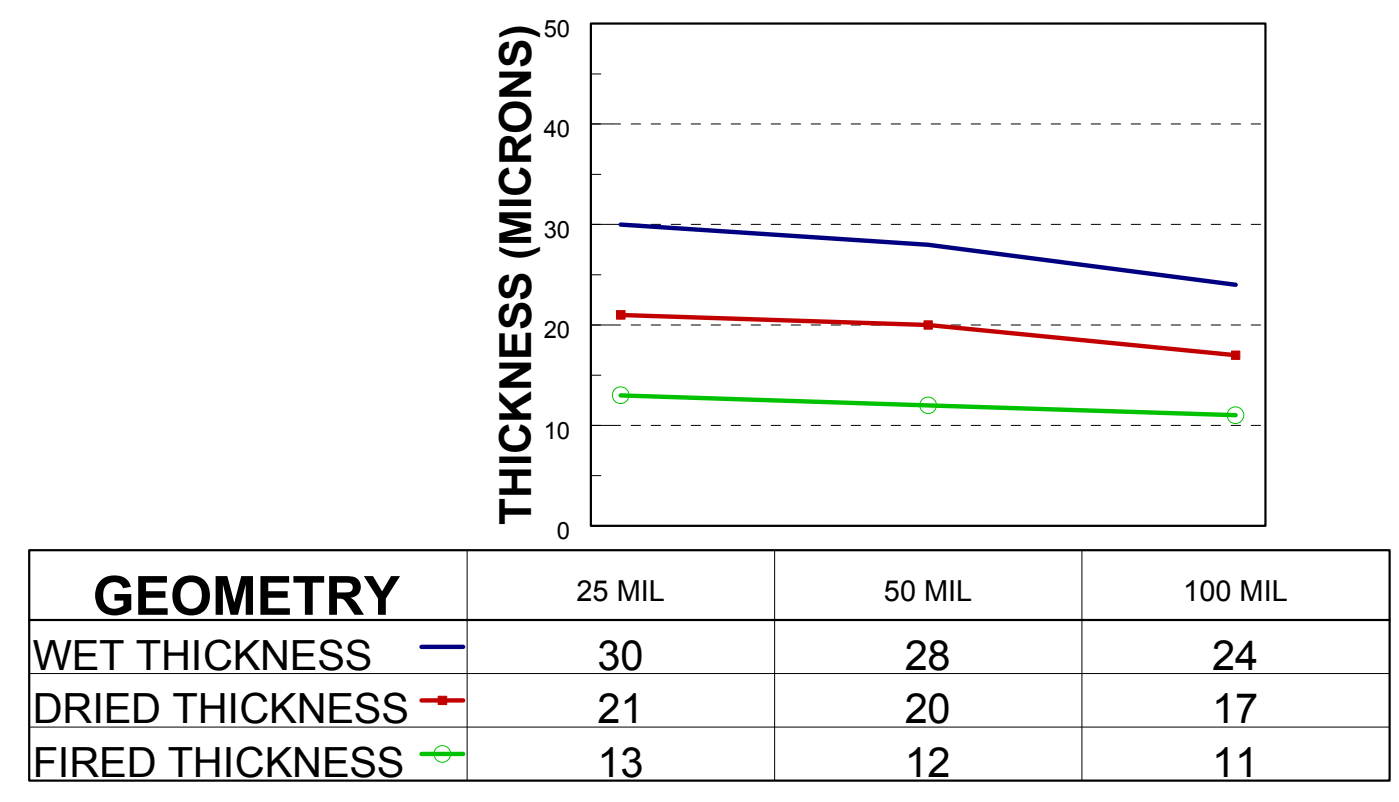

Target Dried Thickness is $18-20$ microns

Figure D-11. Thickness Relationship 
Appendix E

DUPONT 16 RESISTOR PRINTING DATA

ON ALUMINA

(1K Ohm) 


\section{FIRING PROFILE SENSITIVITY DUPONT 16 (1000 OHMS PER SQUARE)}

Actual Values - Printed on Alumina

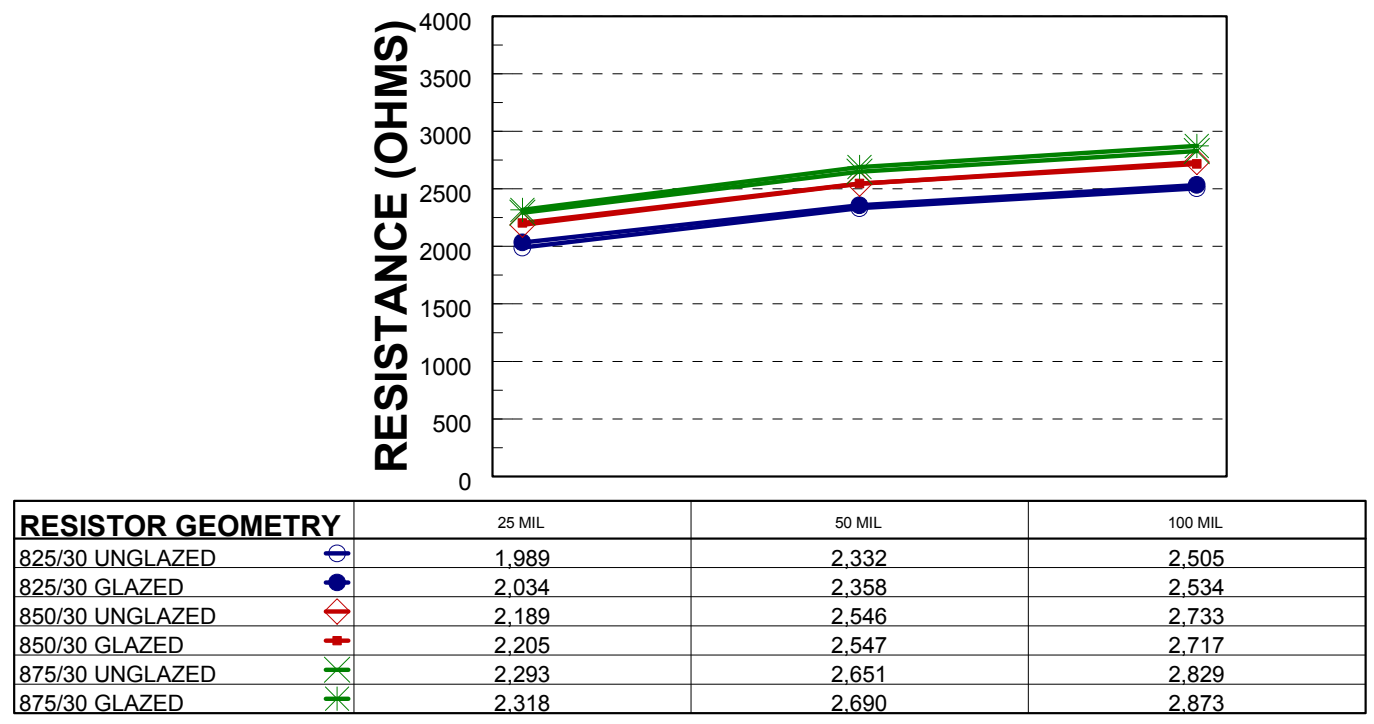

Nominal as-fired resistance is $2000 \mathrm{ohms}$.

Target Dried Thickness is $18-20$ microns

Samples fired in 22

Figure E-1. Firing Profile Sensitivity (Resistance, 1K ohm)

\section{FIRING PROFILE SENSITIVITY} DUPONT 16 (1000 OHMS PER SQUARE)

Percent from Nominal Values - Printed on Alumina

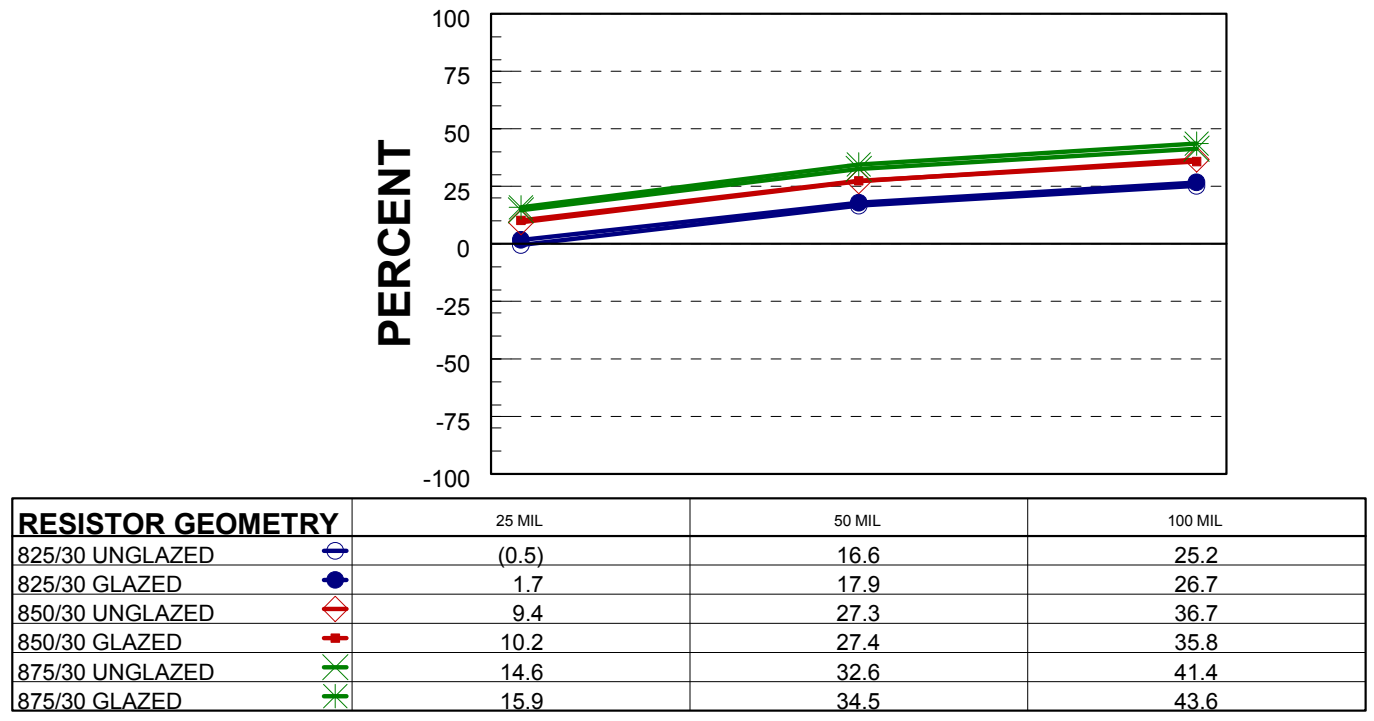

Nominal as-fired resistance is $2000 \mathrm{ohms}$.

Target Dried Thickness is $18-20$ microns

Samples fired in 22

Figure E-2. Firing Profile Sensitivity (Percent, 1K ohm) 


\section{FURNACE SENSITIVITY DUPONT 16 (1000 OHMS PER SQUARE)}

Actual Values - Printed on Alumina

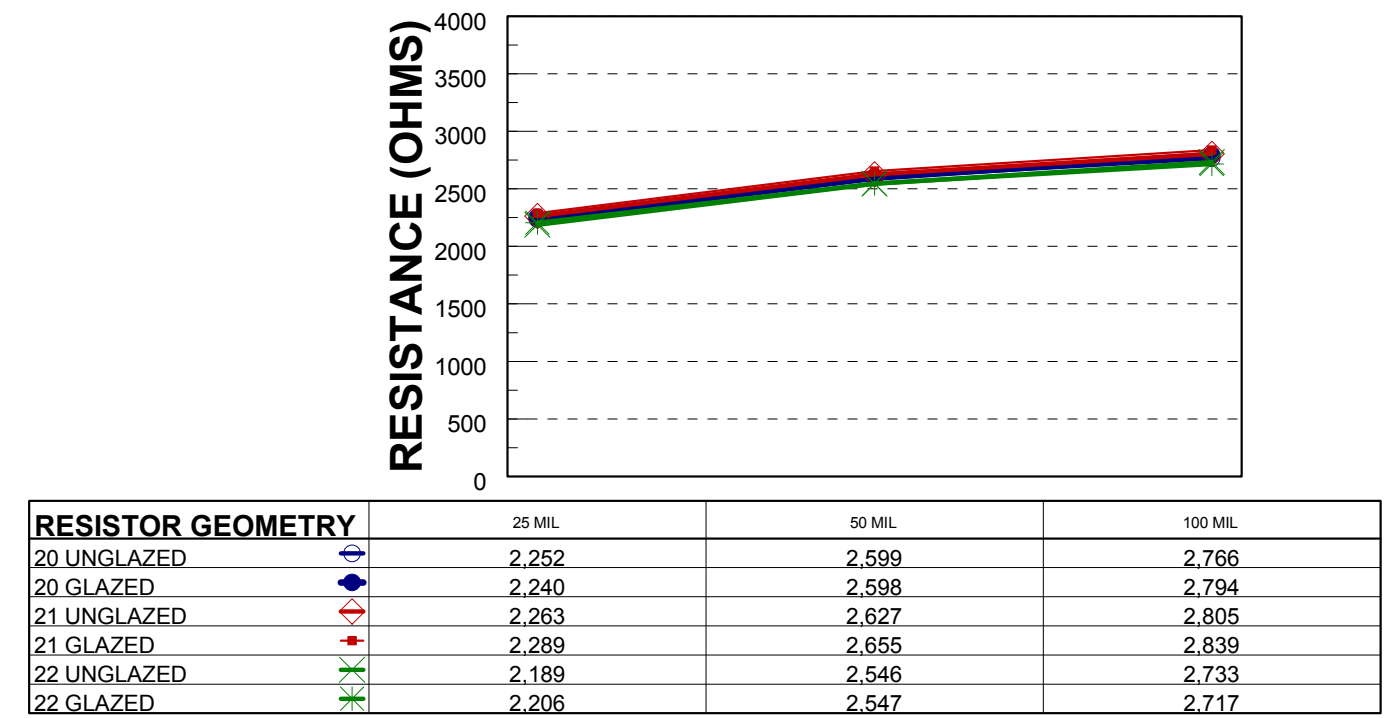

Nominal as-fired resistance is $2000 \mathrm{ohms}$.

Target Dried Thickness is $18-20$ microns

Samples fired with $850 / 30$ profile

Figure E-3. Furnace Sensitivity (Resistance, 1K ohm)

\section{FURNACE SENSITIVITY DUPONT 16 (1000 OHMS PER SQUARE)}

Percent from Nominal Values - Printed on Alumina

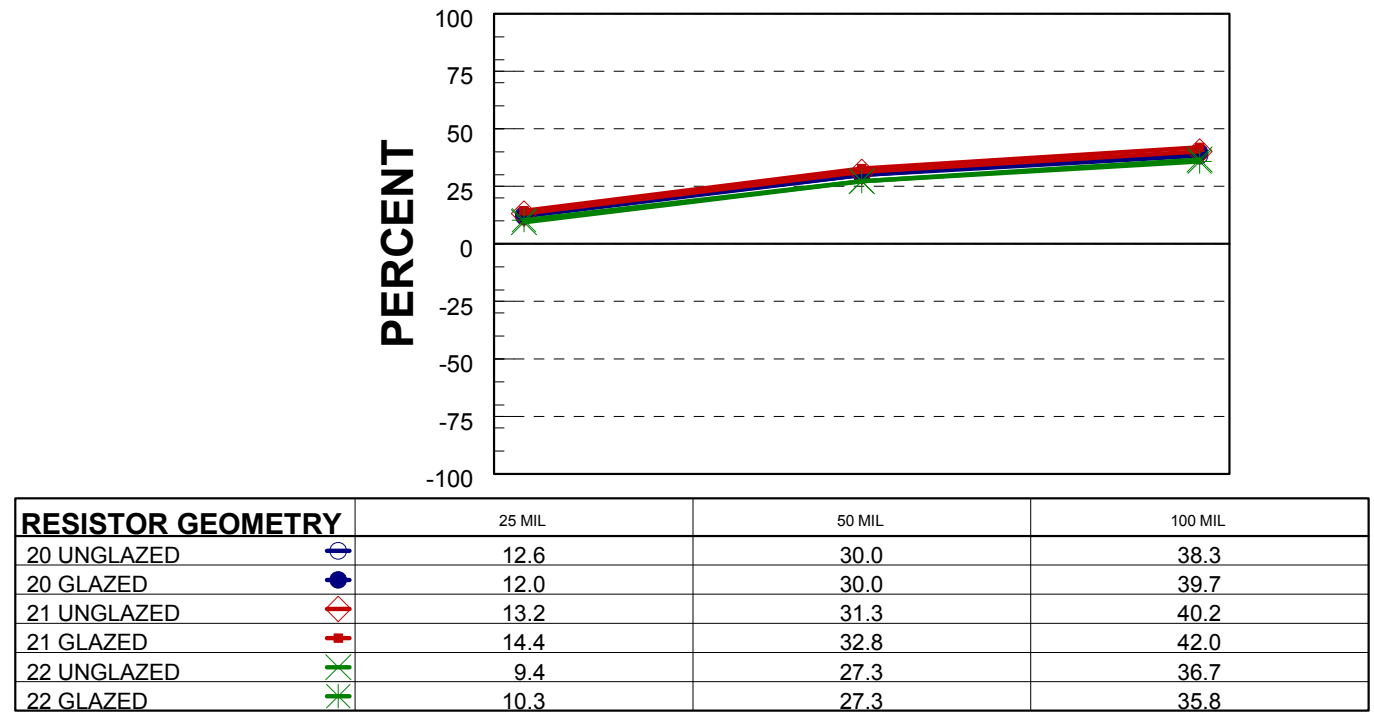

Nominal as-fired resistance is $2000 \mathrm{ohms}$.

Target Dried Thickness is $18-20$ microns

Samples fired with $850 / 30$ profile

Figure E-4. Furnace Sensitivity (Percent, 1K ohm) 


\section{NORMALIZED SHEET RESISTANCE DUPONT 16 (1000 OHMS PER SQUARE)}

Actual Values - Printed on Alumina

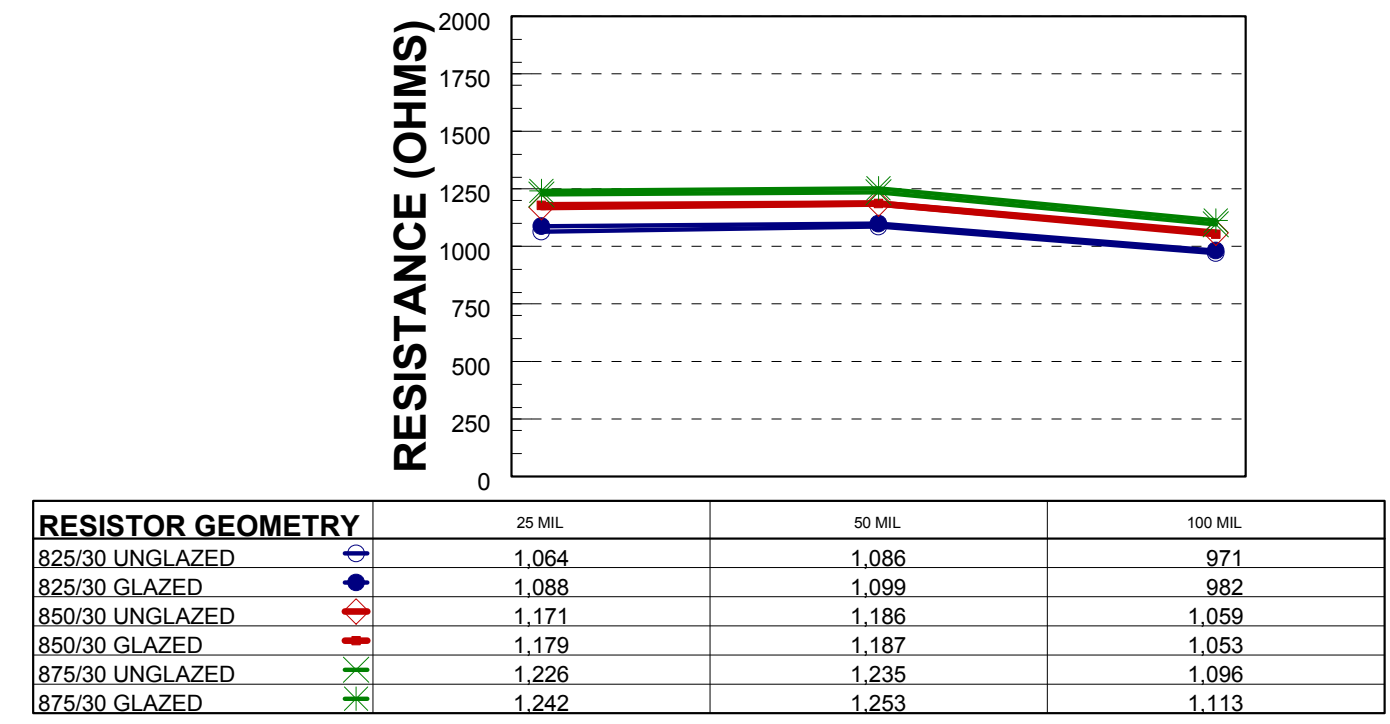

Nominal normalized resistance is 1000 ohms.

Target Dried Thickness is $18-20$ microns

Samples fired in 22

Figure E-5. Normalized Sheet Resistance (Resistance, 1K ohm)

\section{NORMALIZED SHEET RESISTANCE}

\section{DUPONT 16 (1000 OHMS PER SQUARE)}

Percent from Nominal Normalized Resistance - Printed on Alumina

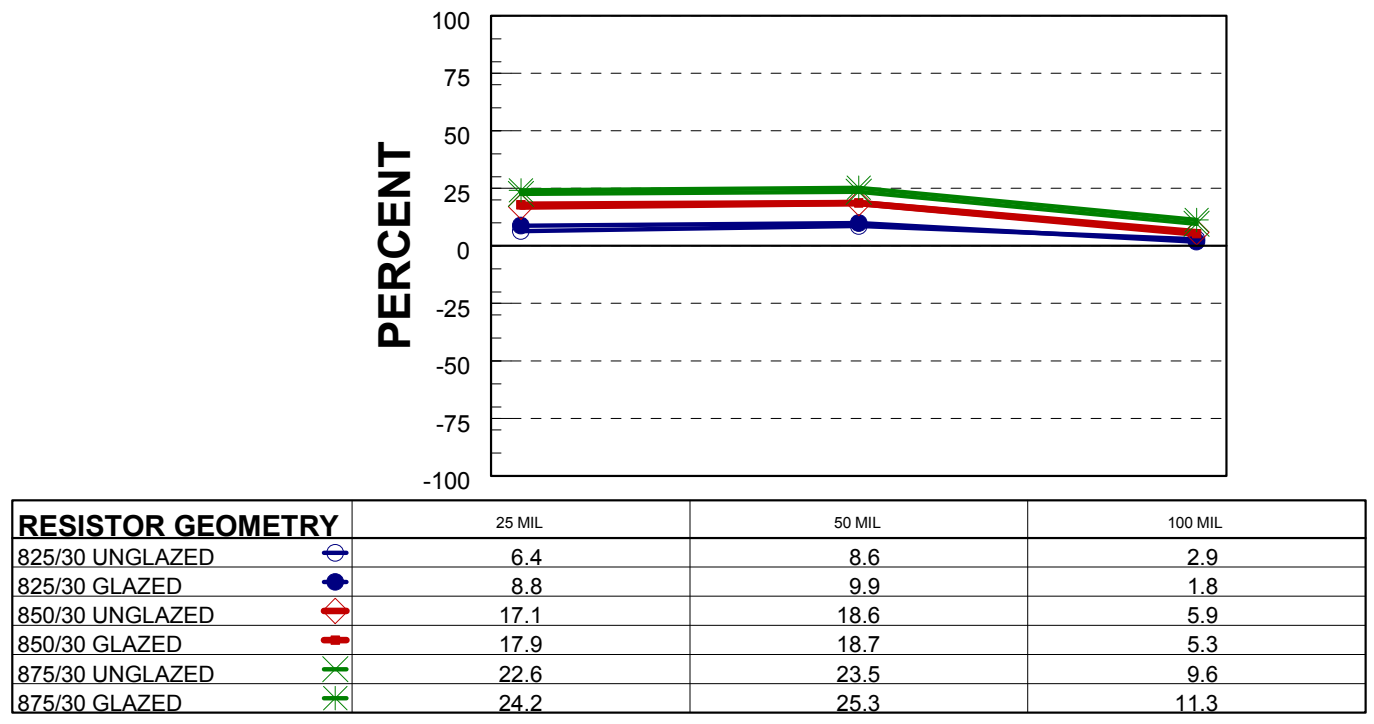

Nominal normalized resistance is $1000 \mathrm{ohms}$.

Target Dried Thickness is $18-20$ microns

Samples fired in 22

Figure E-6. Normalized Sheet Resistance (Percent, 1K ohm) 


\section{NORMALIZED SHEET RESISTANCE DUPONT 16 (1000 OHMS PER SQUARE)}

Actual Values - Printed on Alumina

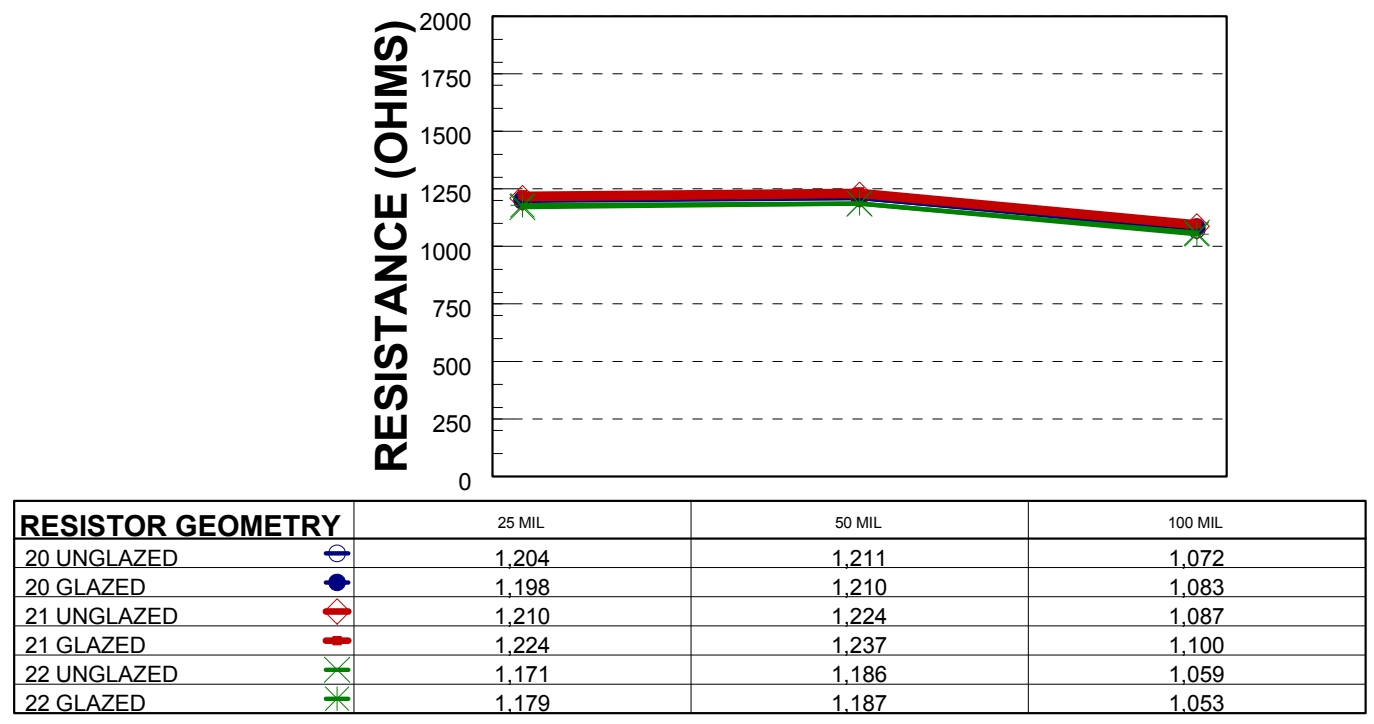

Nominal normalized resistance is 1000 ohms.

Target Dried Thickness is $18-20$ microns

Samples fired with $850 / 30$ profile

Figure E-7. Normalized Sheet Resistance (Resistance, 1K ohm)

\section{NORMALIZED SHEET RESISTANCE}

DUPONT 16 (1000 OHMS PER SQUARE)

Percent from Nominal Normalized Resistance - Printed on Alumina

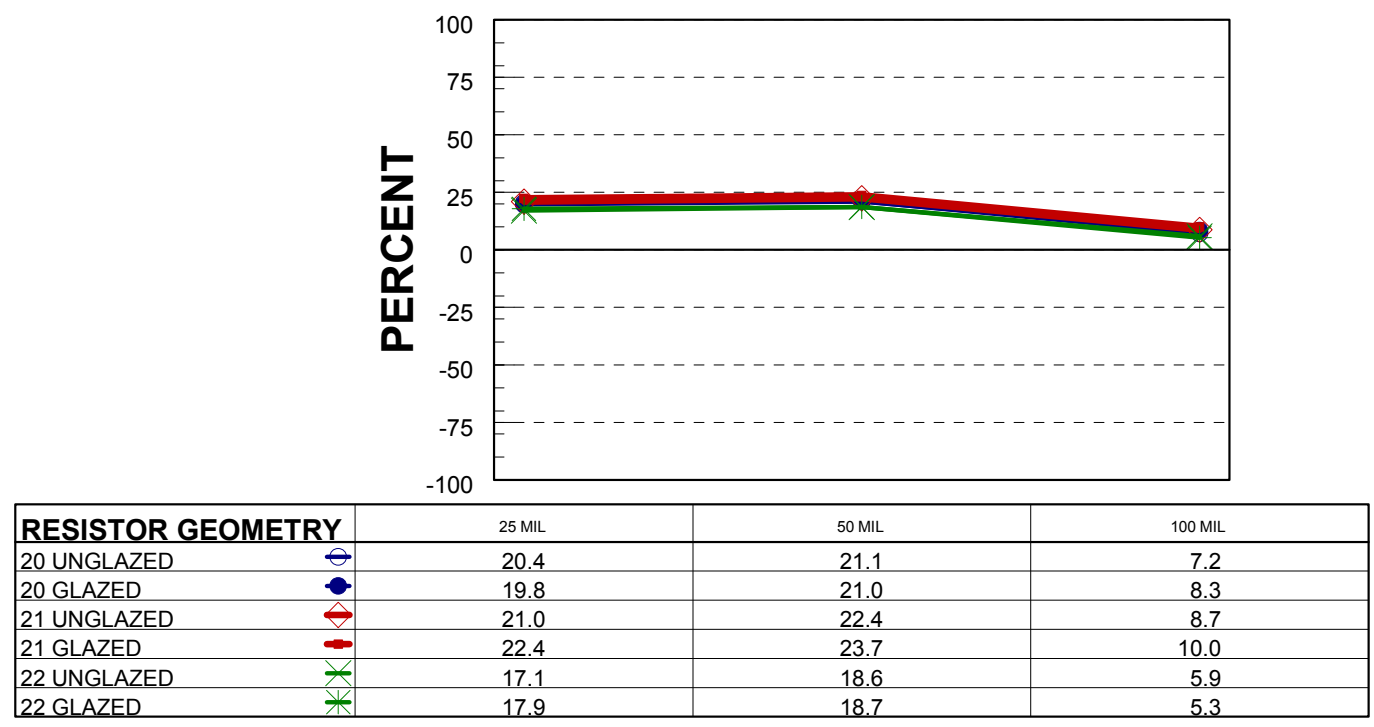

Nominal normalized resistance is $1000 \mathrm{ohms}$.

Target Dried Thickness is $18-20$ microns

Samples fired in 22

Figure E-8. Normalized Sheet Resistance (Percent, 1K ohm) 


\section{THICKNESS \& RESISITIVITY COMPARISON}

DUPONT 16 (1000 OHMS PER SQUARE)

Actual Values - Printed on Alumina

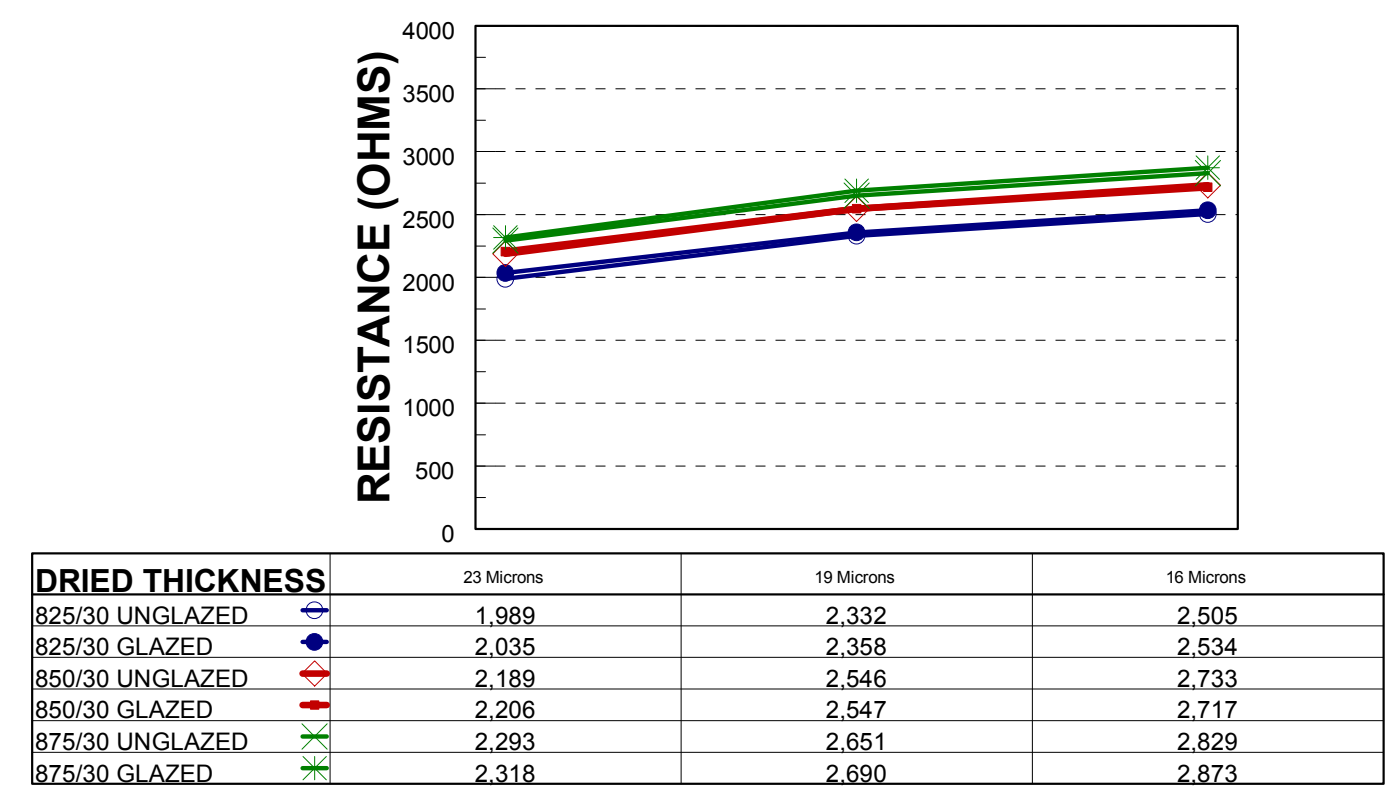

Target Dried Thickness is $18-20$ microns

Figure E-9. Thickness and Resistivity Comparison (Resistance, 1K ohm)

\section{THICKNESS \& RESISITIVITY COMPARISON}

\section{DUPONT 16 (1000 OHMS PER SQUARE)}

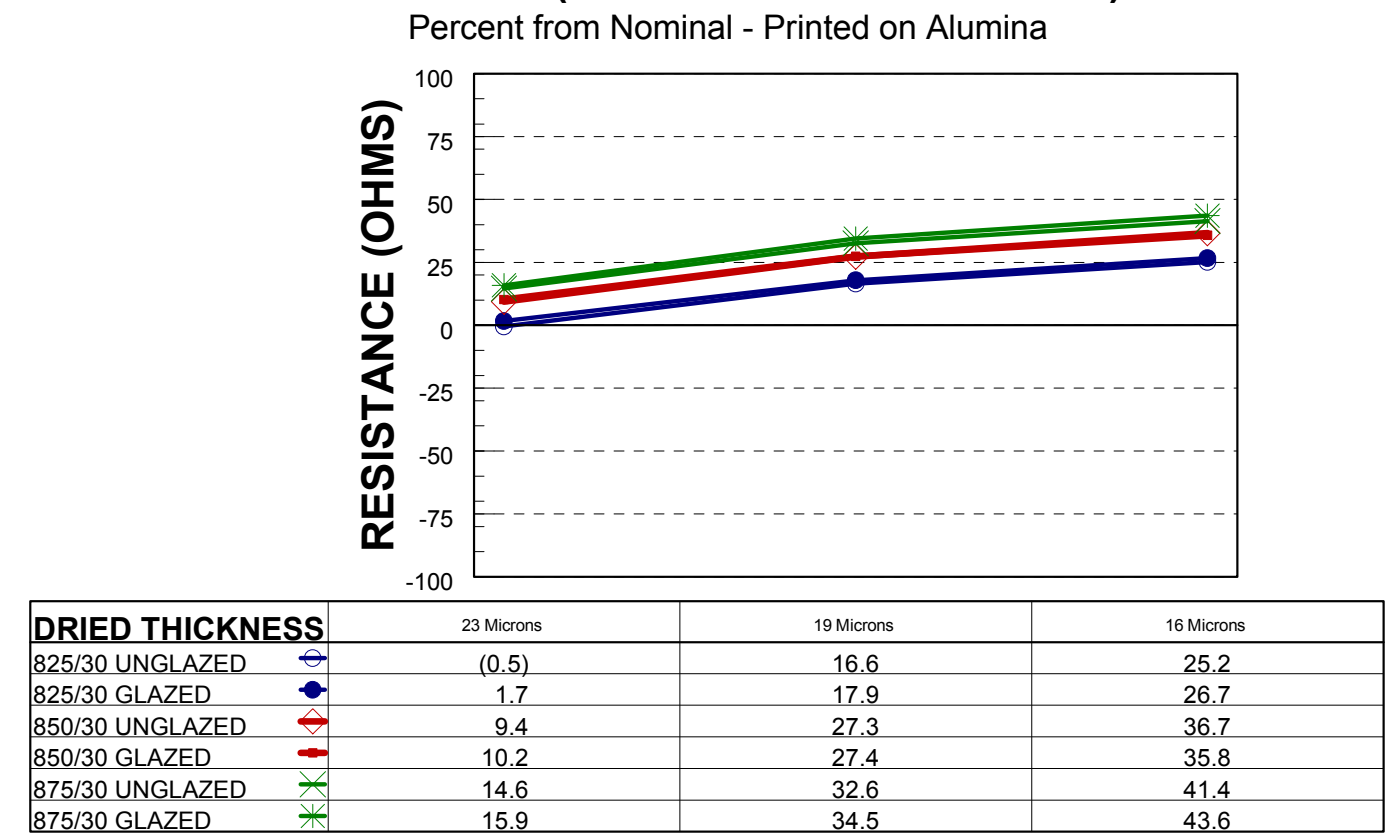

Target Dried Thickness is $18-20$ microns

Figure E-10. Thickness and Resistivity Comparison (Resistance, $1 \mathrm{~K}$ ohm) 


\section{THICKNESS RELATIONSHIP DUPONT 16 (1000 OHMS PER SQUARE)}

Printed on Alumina

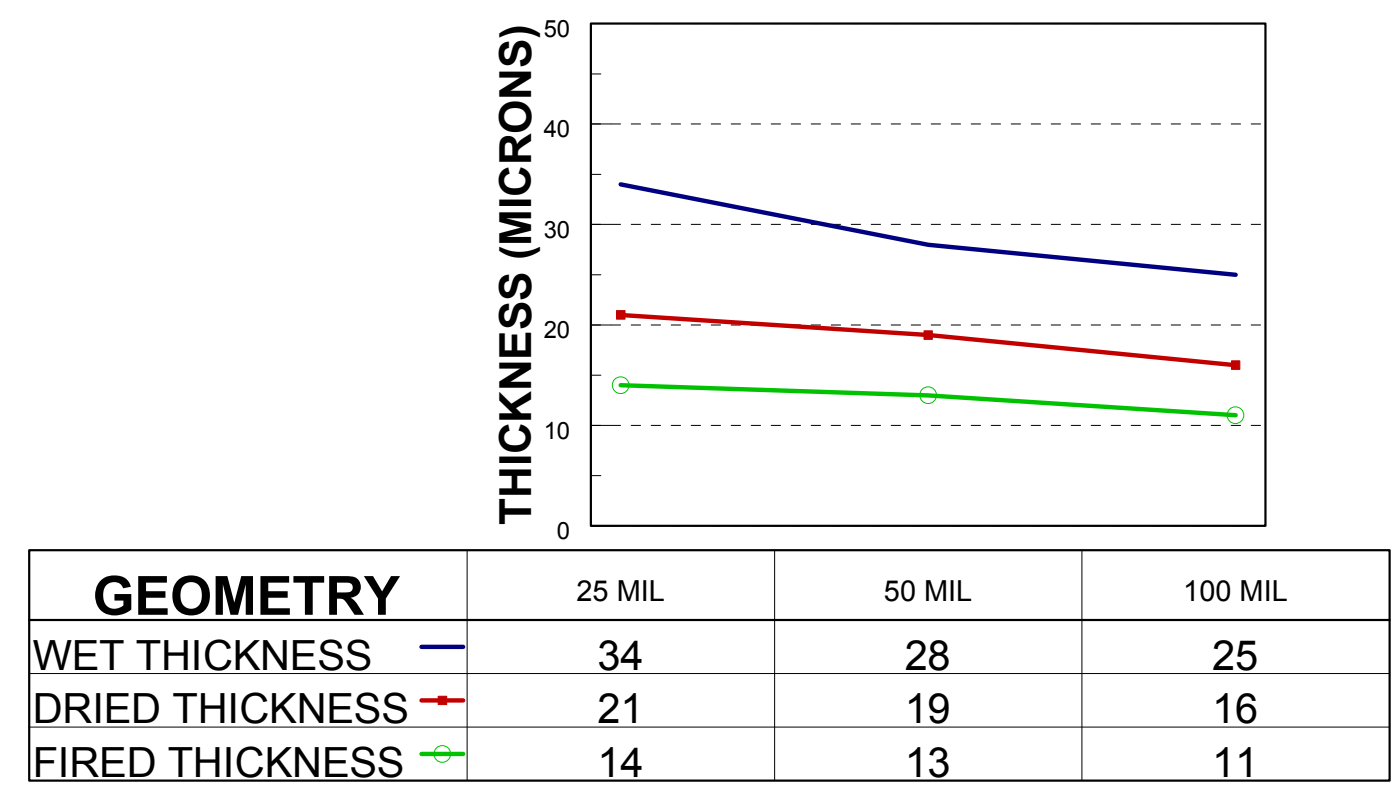

Target Dried Thickness is $18-20$ microns

Figure E-11. Thickness Relationship 
Appendix F

\section{DUPONT 17 RESISTOR PRINTING DATA \\ ON ALUMINA \\ (10K Ohm)}




\title{
FIRING PROFILE SENSITIVITY DUPONT 17 (10K OHMS PER SQUARE)
}

\author{
Actual Values - Printed on Alumina
}

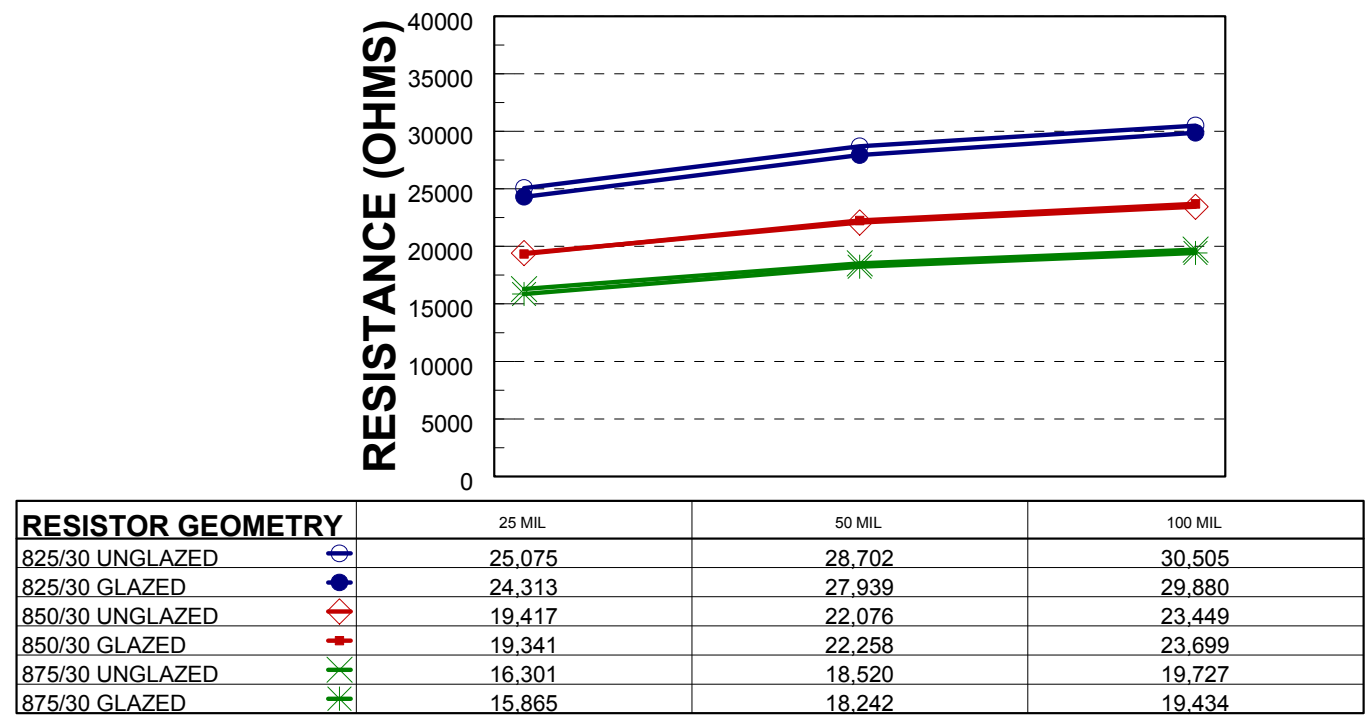

Nominal as-fired resistance is $20,000 \mathrm{ohms}$.

Target Dried Thickness is $18-20$ microns

Samples fired in 22

Figure F-1. Firing Profile Sensitivity (Resistance, 10K ohm)

\section{FIRING PROFILE SENSITIVITY DUPONT 17 (10K OHMS PER SQUARE)}

Percent from Nominal Values - Printed on Alumina

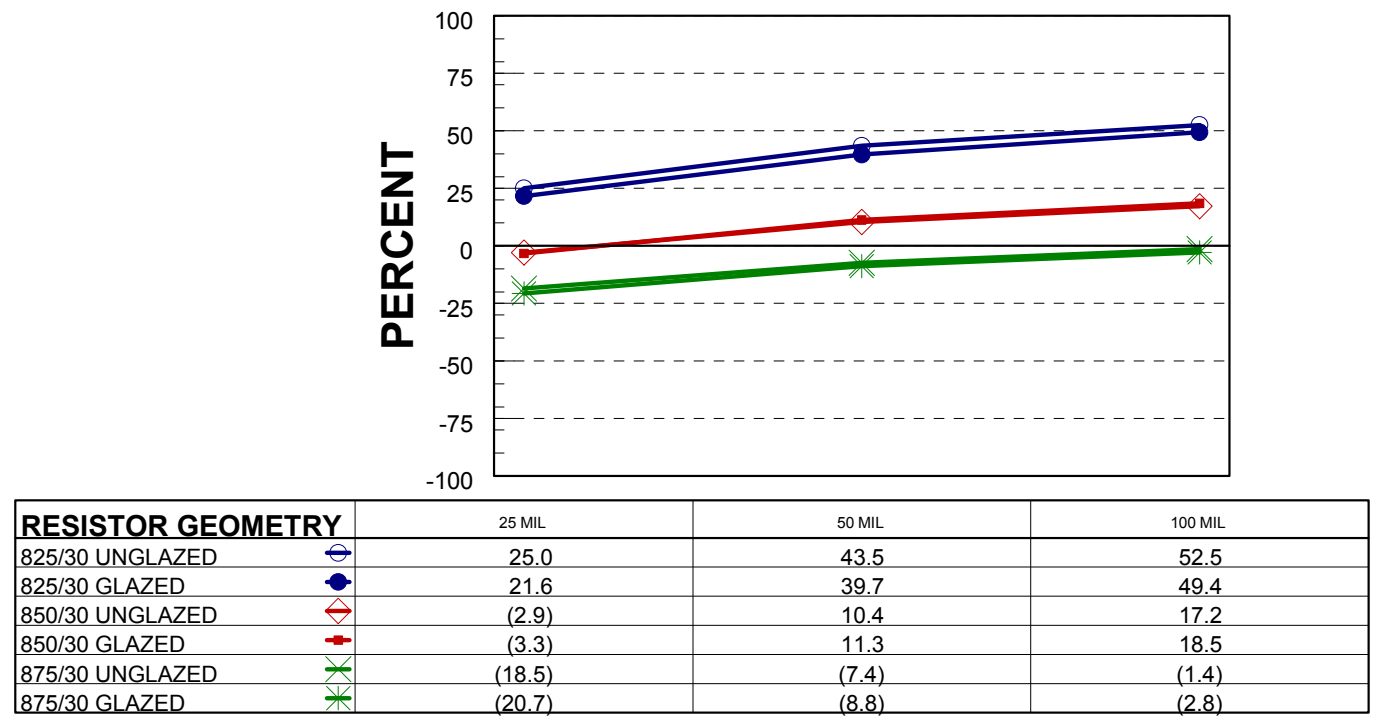

Nominal as-fired resistance is 20,000 ohms.

Target Dried Thickness is $18-20$ microns

Samples fired in 22

Figure F-2. Firing Profile Sensitivity (Percent, 10K ohm) 


\section{FURNACE SENSITIVITY DUPONT 17 (10K OHMS PER SQUARE)}

Actual Values - Printed on Alumina

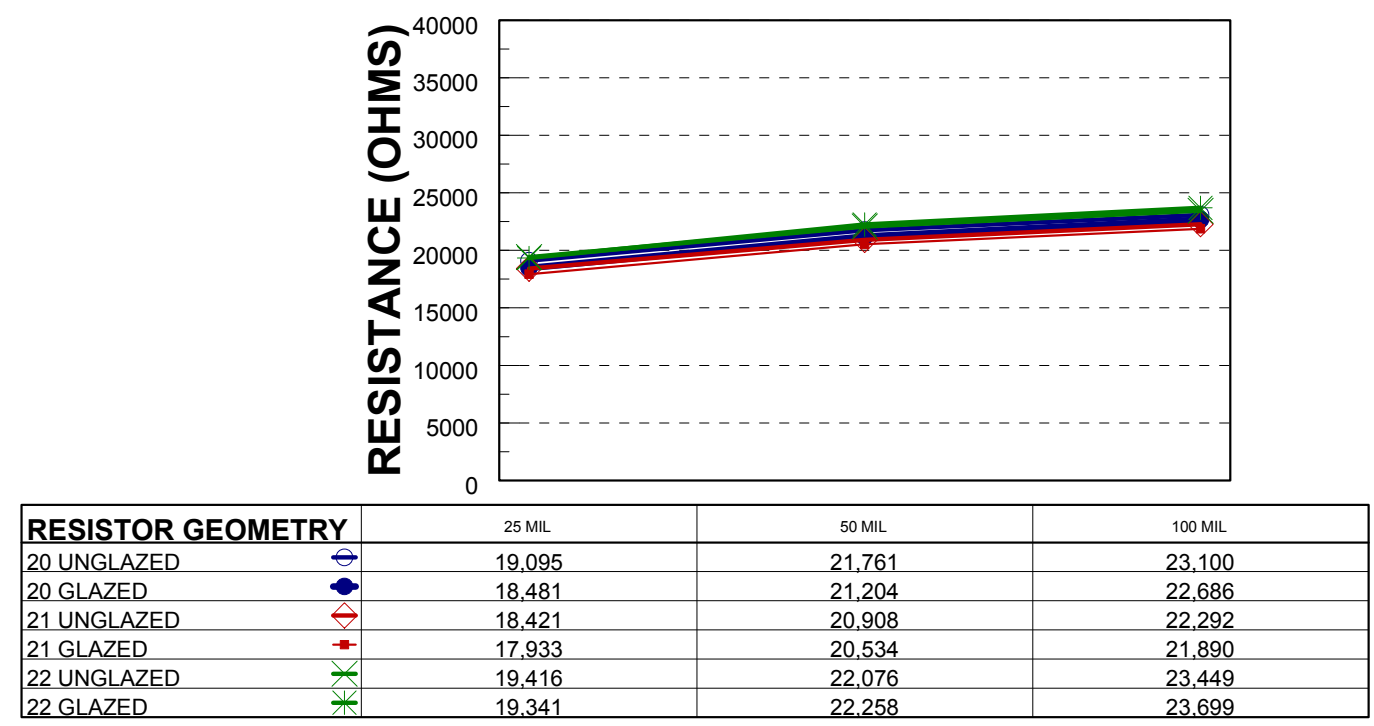

Nominal as-fired resistance is 20,000 ohms.

Target Dried Thickness is $18-20$ microns

Samples fired with $850 / 30$ profile

Figure F-3. Furnace Sensitivity (Resistance, 10K ohm)

\section{FURNACE SENSITIVITY DUPONT 17 (10K OHMS PER SQUARE)}

Percent from Nominal Values - Printed on Alumina

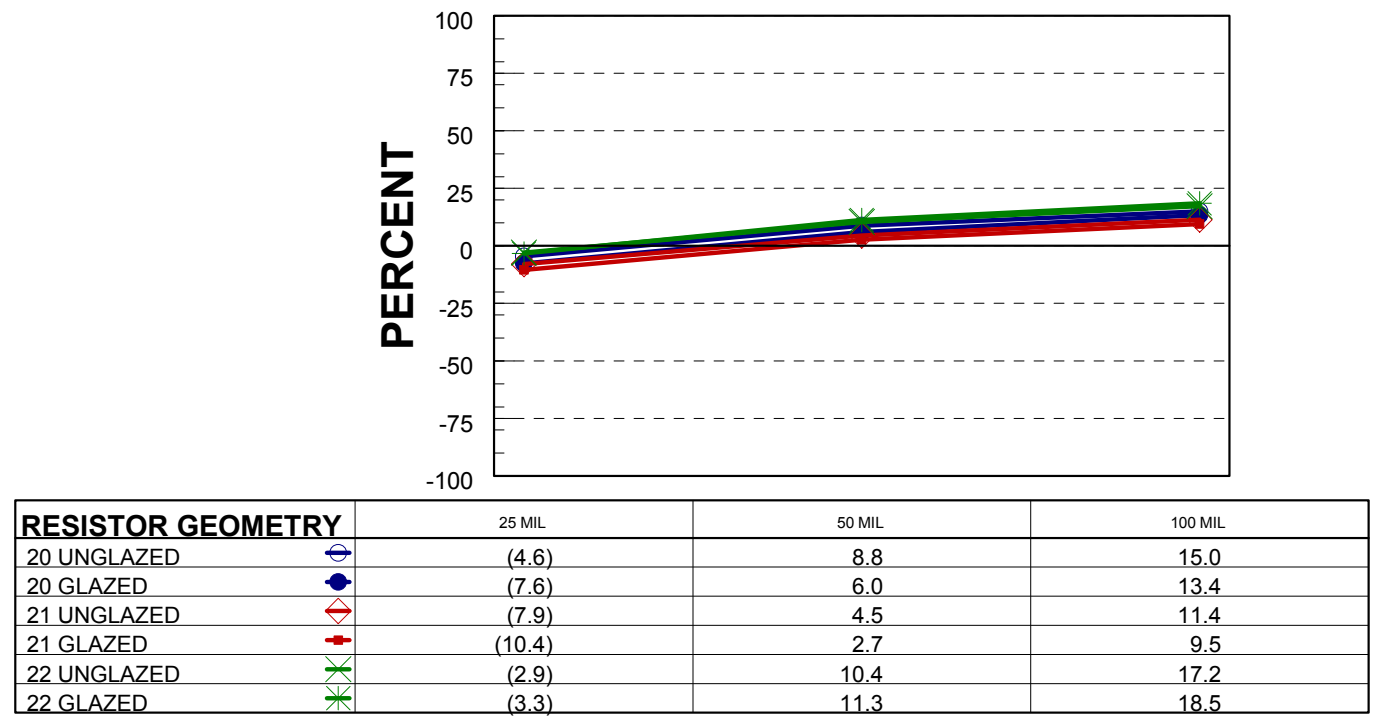

Nominal as-fired resistance is 20,000 ohms.

Target Dried Thickness is $18-20$ microns

Samples fired with $850 / 30$ profile

Figure F-4. Furnace Sensitivity (Percent, 10K ohm) 


\section{NORMALIZED SHEET RESISTANCE DUPONT 17 (10K OHMS PER SQUARE)}

Actual Values - Printed on Alumina

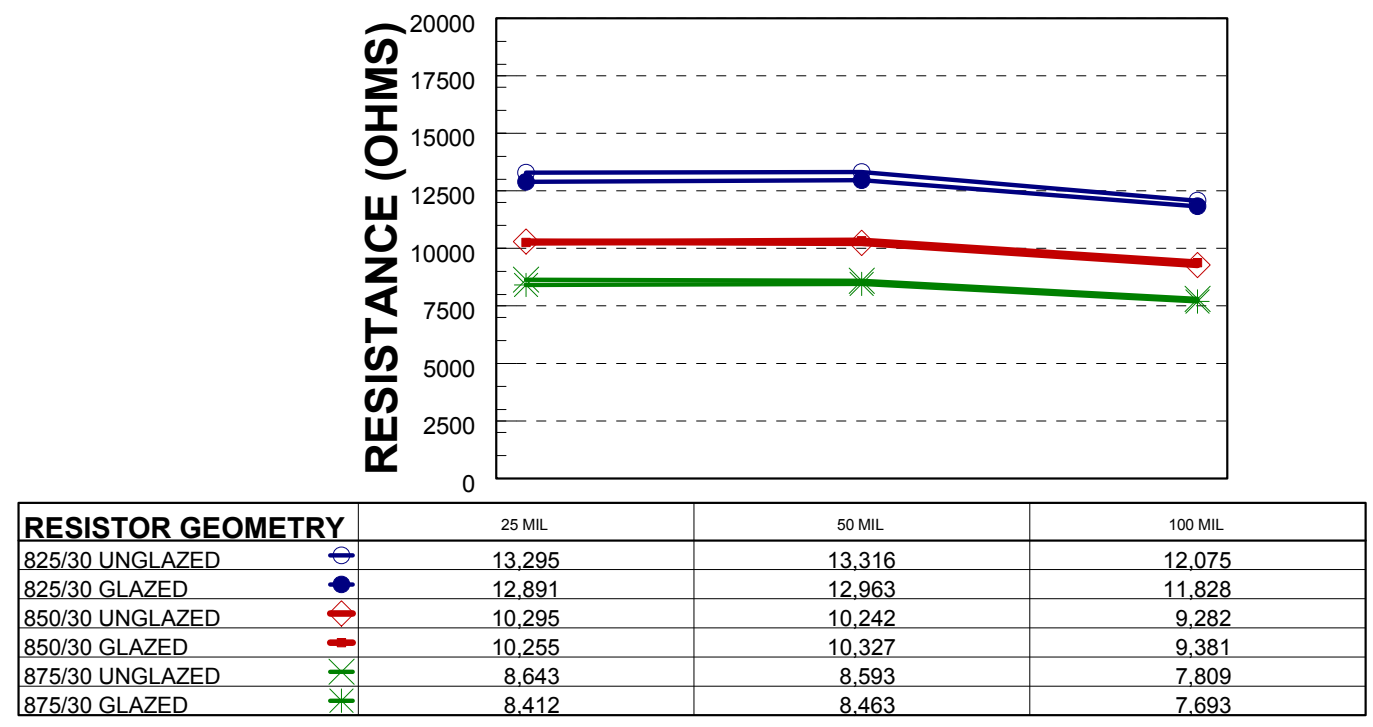

Nominal normalized resistance is 10,000 ohms.

Target Dried Thickness is $18-20$ microns

Samples fired in 22

Figure F-5. Normalized Sheet Resistance (Resistance, 10K ohm)

\section{NORMALIZED SHEET RESISTANCE DUPONT 17 (10K OHMS PER SQUARE)}

Percent from Nominal Normalized Resistance - Printed on Alumina

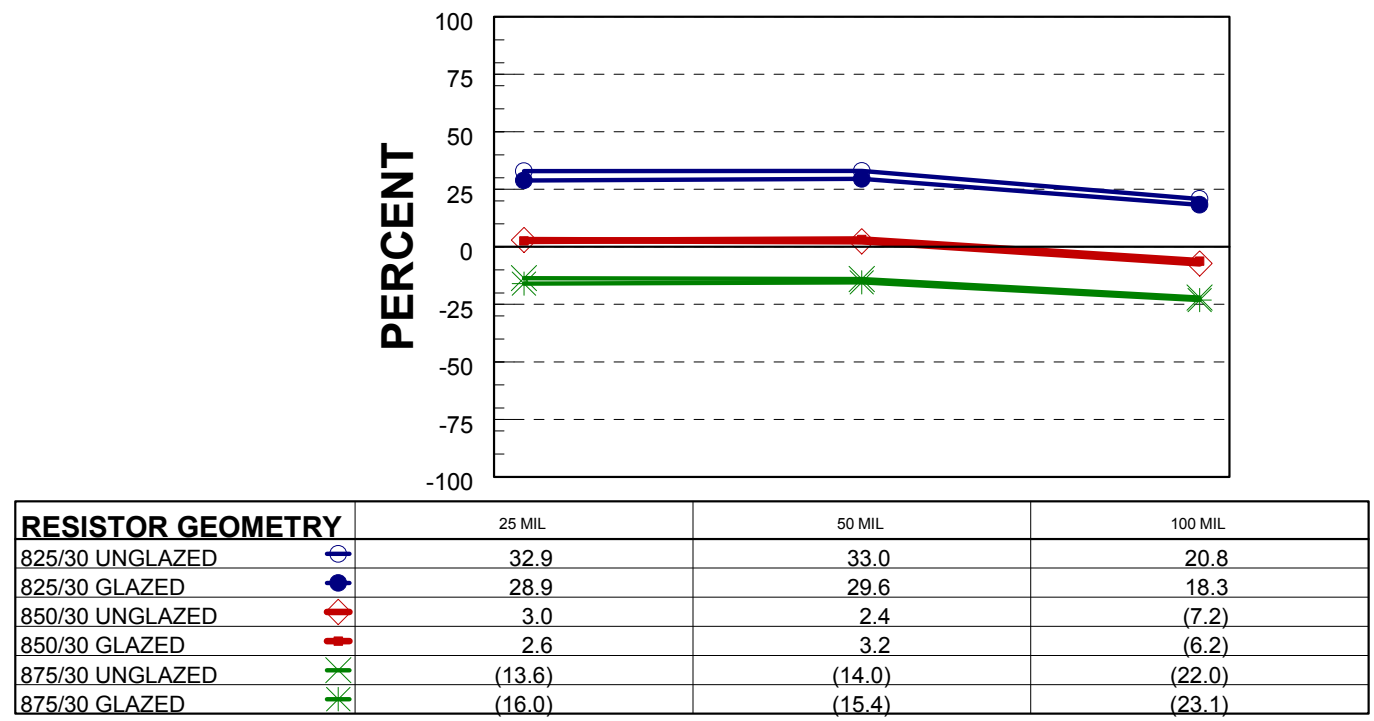

Nominal normalized resistance is 10,000 ohms.

Target Dried Thickness is $18-20$ microns

Samples fired in 22

Figure F-6. Normalized Sheet Resistance (Percent, 10K ohm) 


\section{NORMALIZED SHEET RESISTANCE DUPONT 17 (10K OHMS PER SQUARE)}

Actual Values - Printed on Alumina

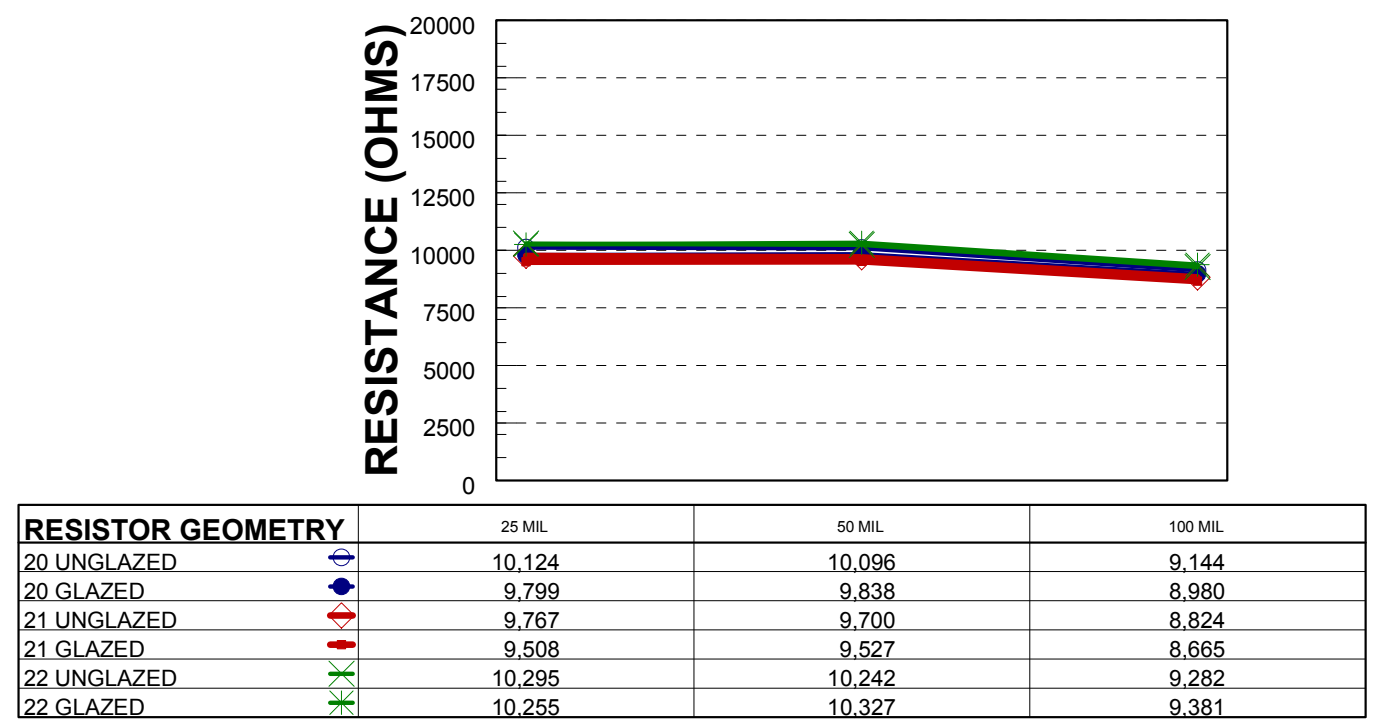

Nominal normalized resistance is 10,000 ohms.

Target Dried Thickness is $18-20$ microns

Samples fired with $850 / 30$ profile

Figure F-7. Normalized Sheet Resistance (Resistance, 10K ohm)

\section{NORMALIZED SHEET RESISTANCE DUPONT 17 (10K OHMS PER SQUARE)}

Percent from Nominal Normalized Resistance - Printed on Alumina

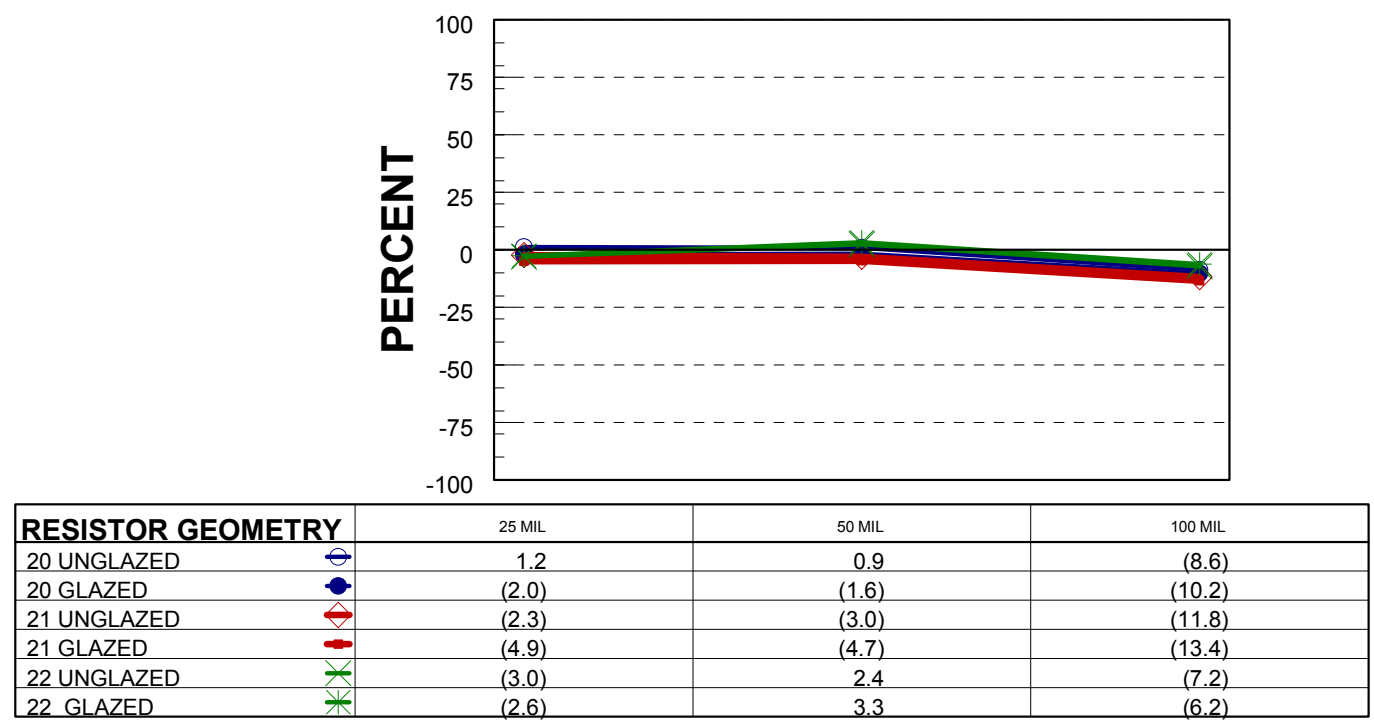

Nominal normalized resistance is 10,000 ohms.

Target Dried Thickness is $18-20$ microns

Samples fired in 22

Figure F-8. Normalized Sheet Resistance (Percent, 10K ohm) 


\section{THICKNESS \& RESISITIVITY COMPARISON}

DUPONT 17 (10K OHMS PER SQUARE)

Actual Values - Printed on Alumina

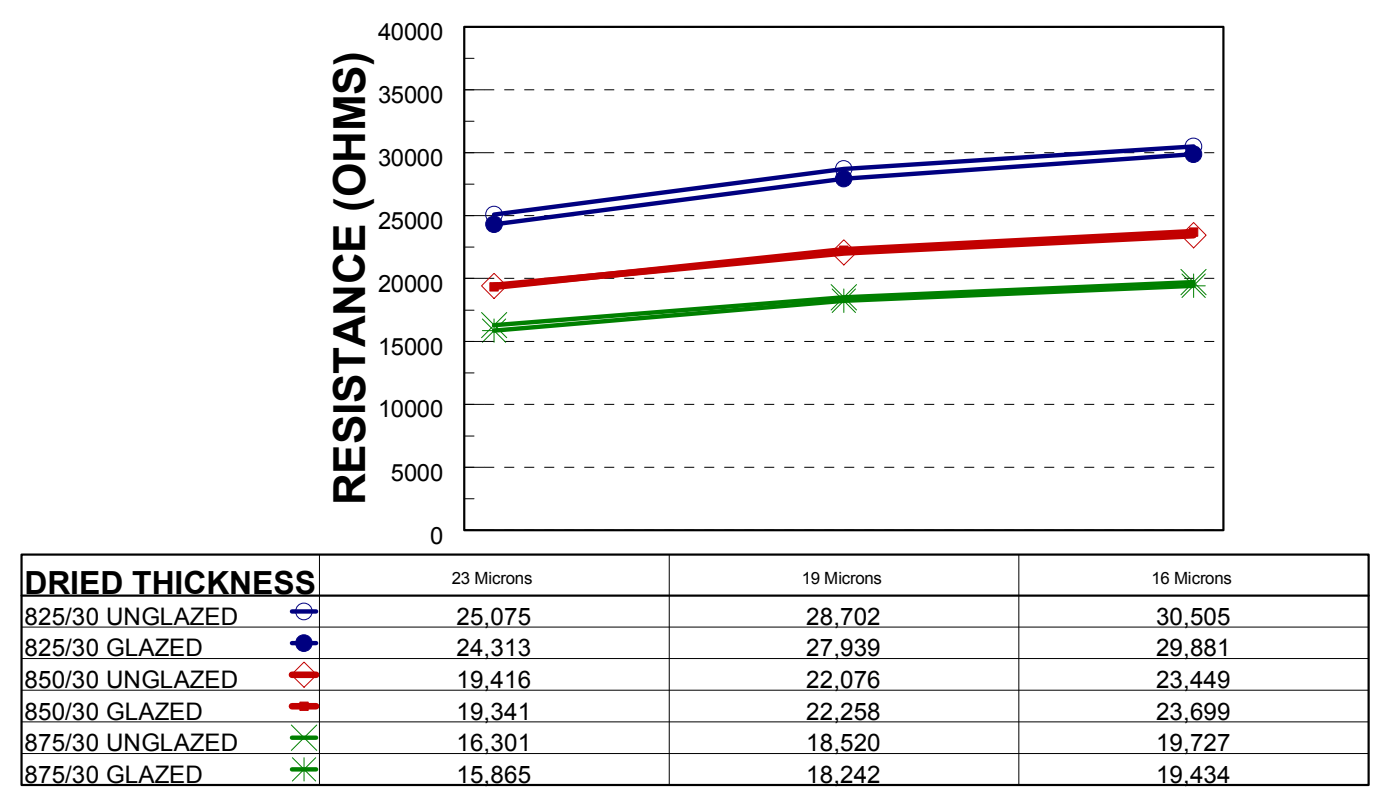

Target Dried Thickness is $18-20$ microns

Figure F-9. Thickness and Resistivity Comparison (Resistance 10K ohm)

\section{THICKNESS \& RESISITIVITY COMPARISON} DUPONT 17 (10K OHMS PER SQUARE)

Percent from Nominal - Printed on Alumina

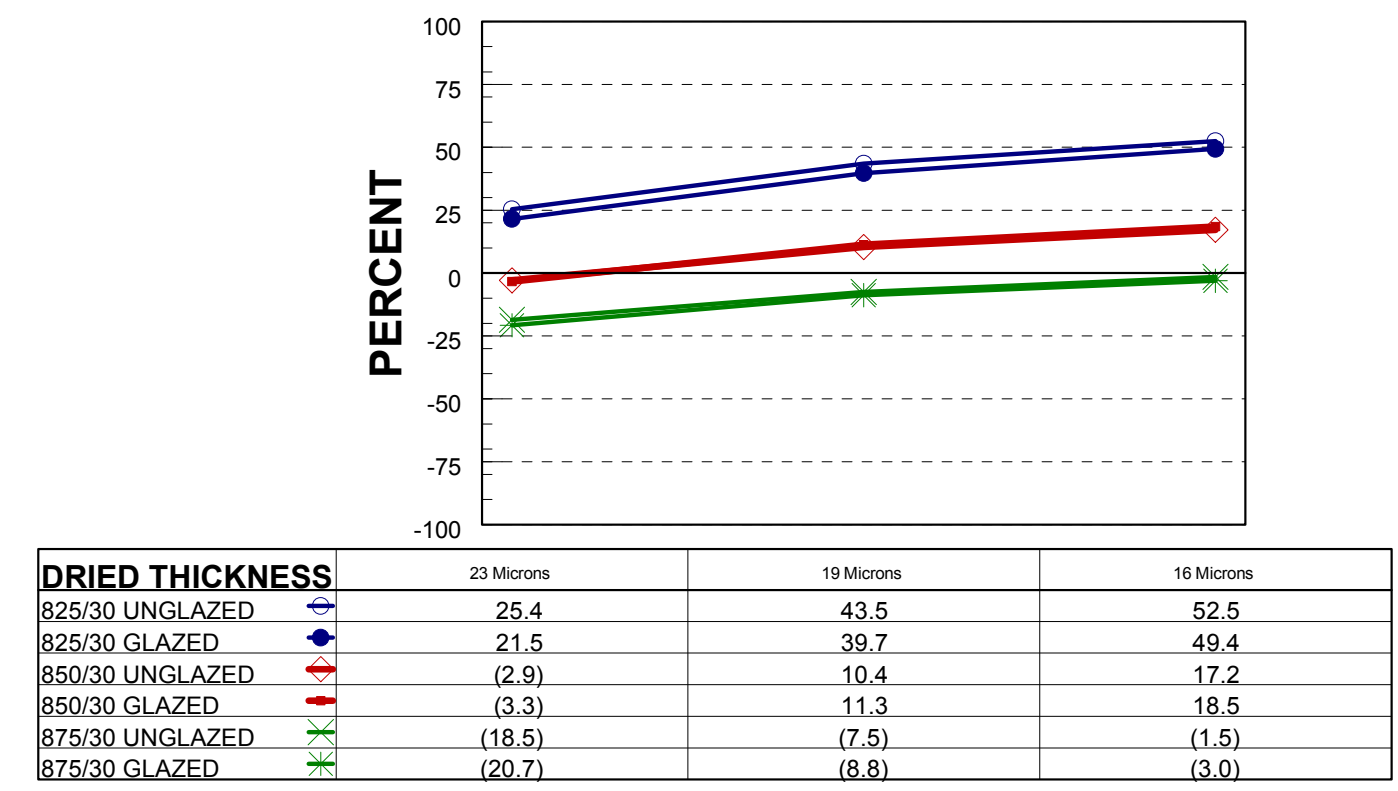

Target Dried Thickness is $18-20$ microns

Figure F-10. Thickness and Resistivity Comparison (Percent, 10K ohm) 


\section{THICKNESS RELATIONSHIP \\ DUPONT 17 (10K OHMS PER SQUARE)}

Printed on Alumina

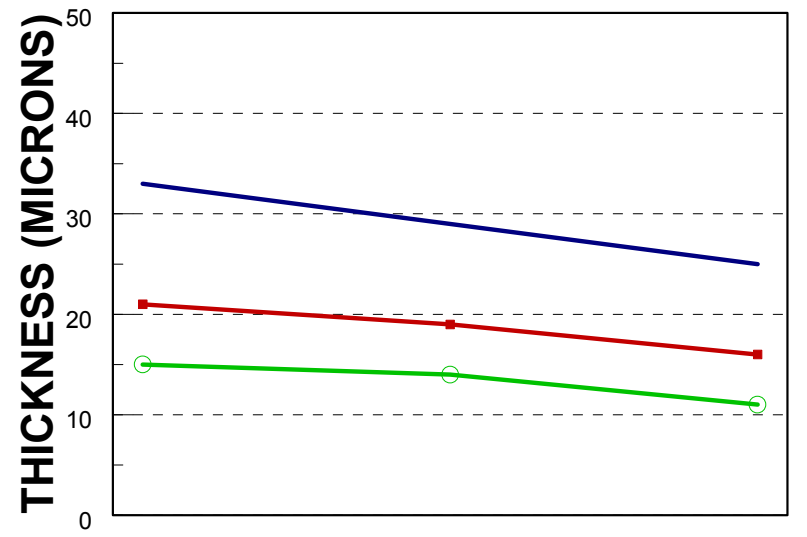

\begin{tabular}{|l|c|c|c|}
\hline GEOMETRY & $25 \mathrm{MIL}$ & $50 \mathrm{MIL}$ & $100 \mathrm{MIL}$ \\
\hline WET THICKNESS - & 33 & 29 & 25 \\
\hline DRIED THICKNESS - & 21 & 19 & 16 \\
\hline FIRED THICKNESS - & 15 & 14 & 11 \\
\hline
\end{tabular}

Target Dried Thickness is $18-20$ microns

Figure F-11. Thickness Relationship 


\section{Appendix G}

\section{DUPONT 18 RESISTOR PRINTING DATA \\ ON ALUMINA \\ (100K Ohm)}




\section{FIRING PROFILE SENSITIVITY DUPONT 18 (100K OHMS PER SQUARE)}

Actual Values - Printed on Alumina

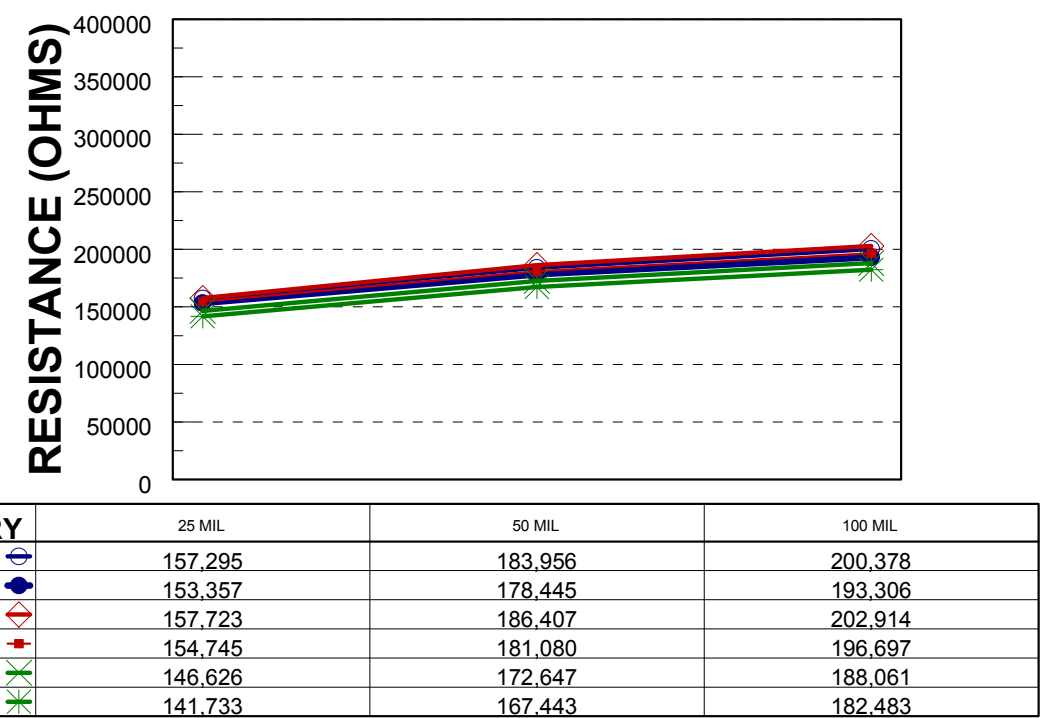

Nominal as-fired resistance is 200,000 ohms.

Target Dried Thickness is $18-20$ microns

Samples fired in 18

Figure G-1. Firing Profile Sensitivity (Resistance 100K ohm)

\section{FIRING PROFILE SENSITIVITY} DUPONT 18 (100K OHMS PER SQUARE)

Percent from Nominal Values - Printed on Alumina

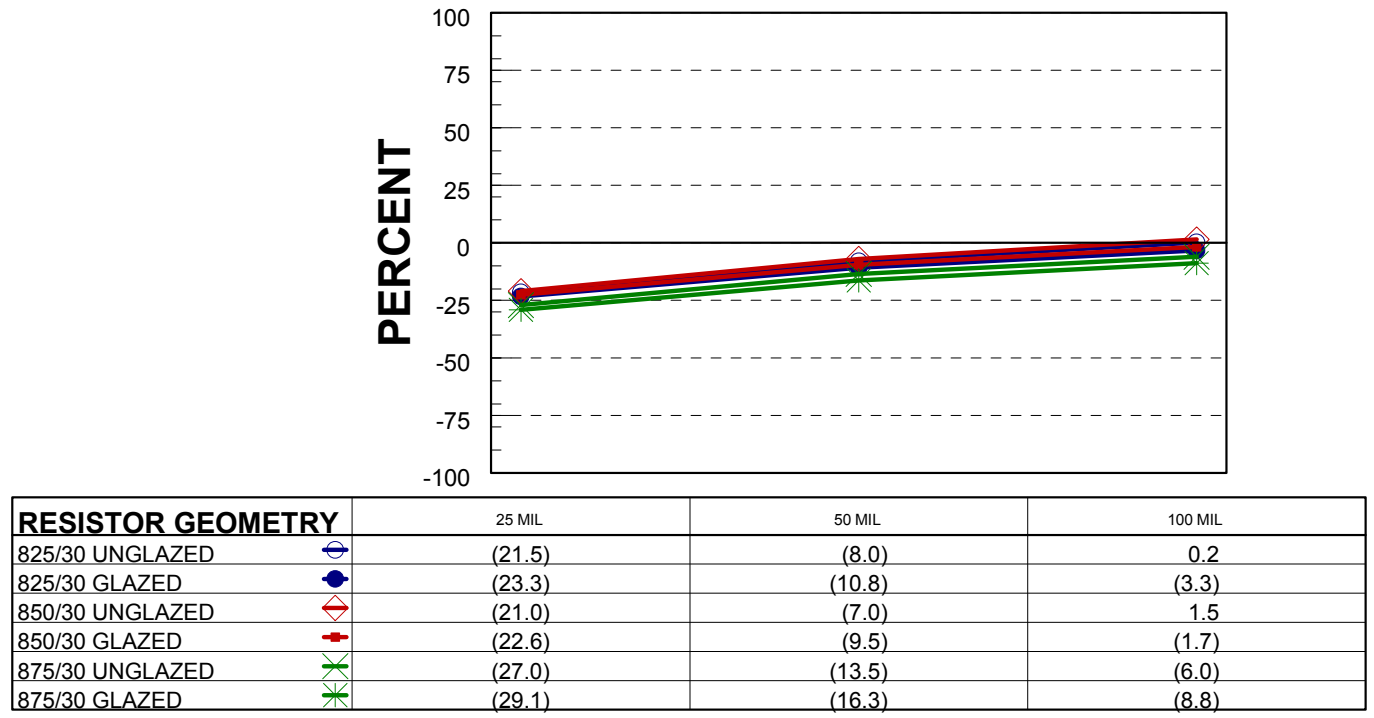

Nominal as-fired resistance is $200,000 \mathrm{ohms}$.

Target Dried Thickness is $18-20$ microns

Samples fired in 22

Figure G-2. Firing Profile Sensitivity (Percent, 100K ohm) 


\section{FURNACE SENSITIVITY DUPONT 18 (100K OHMS PER SQUARE)}

Actual Values - Printed on Alumina

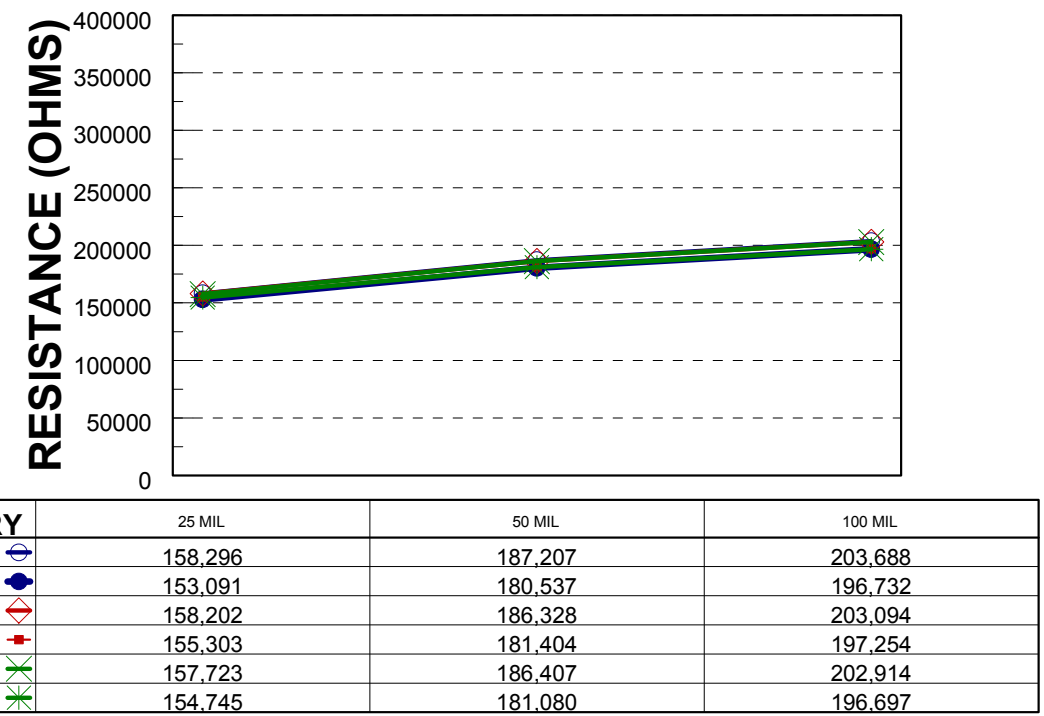

Nominal as-fired resistance is 200,000 ohms.

Target Dried Thickness is $18-20$ microns

Samples fired with $850 / 30$ profile

Figure G-3. Furnace Sensitivity (Resistance, 100K ohm)

\section{FURNACE SENSITIVITY DUPONT 18 (100K OHMS PER SQUARE)}

Percent from Nominal Values - Printed on Alumina

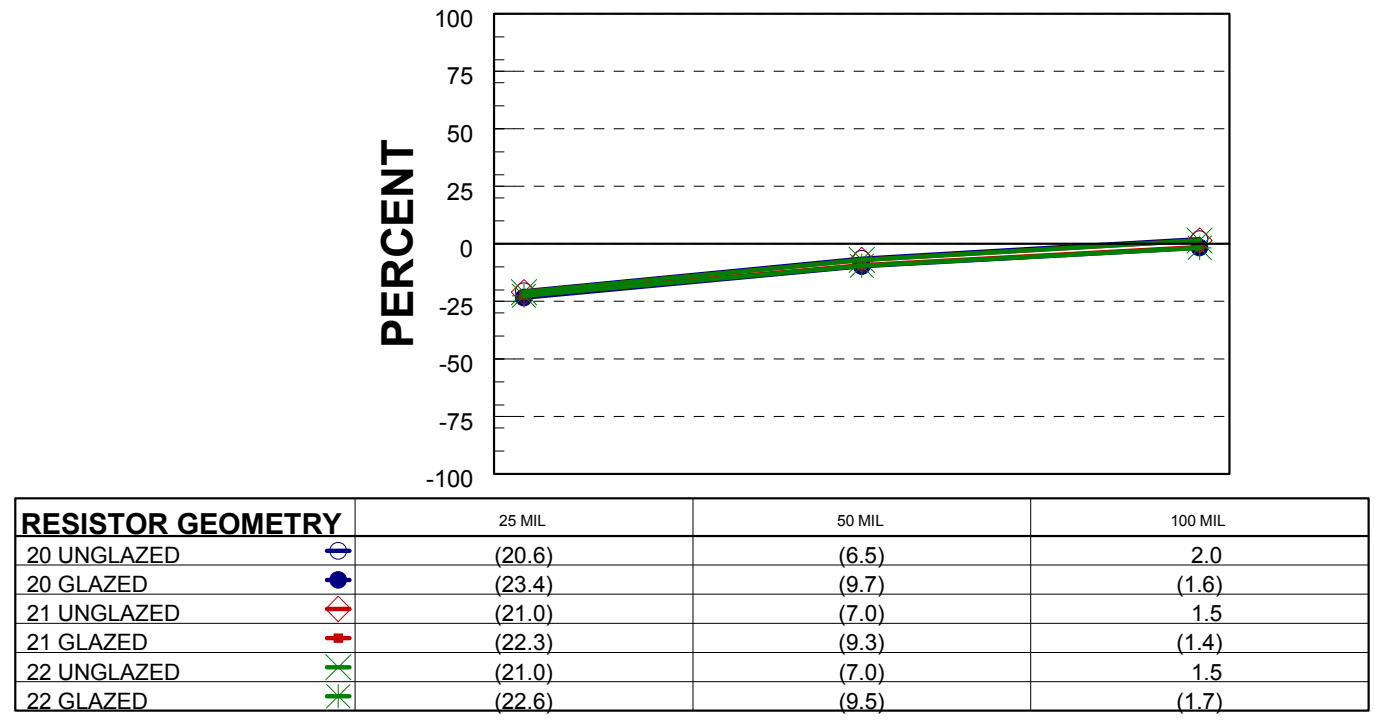

Nominal as-fired resistance is $200,000 \mathrm{ohms}$.

Target Dried Thickness is $18-20$ microns

Samples fired with $850 / 30$ profile

Figure G-4. Furnace Sensitivity (Percent, 100K ohm) 


\section{NORMALIZED SHEET RESISTANCE DUPONT 18 (100K OHMS PER SQUARE) \\ Actual Values - Printed on Alumina}

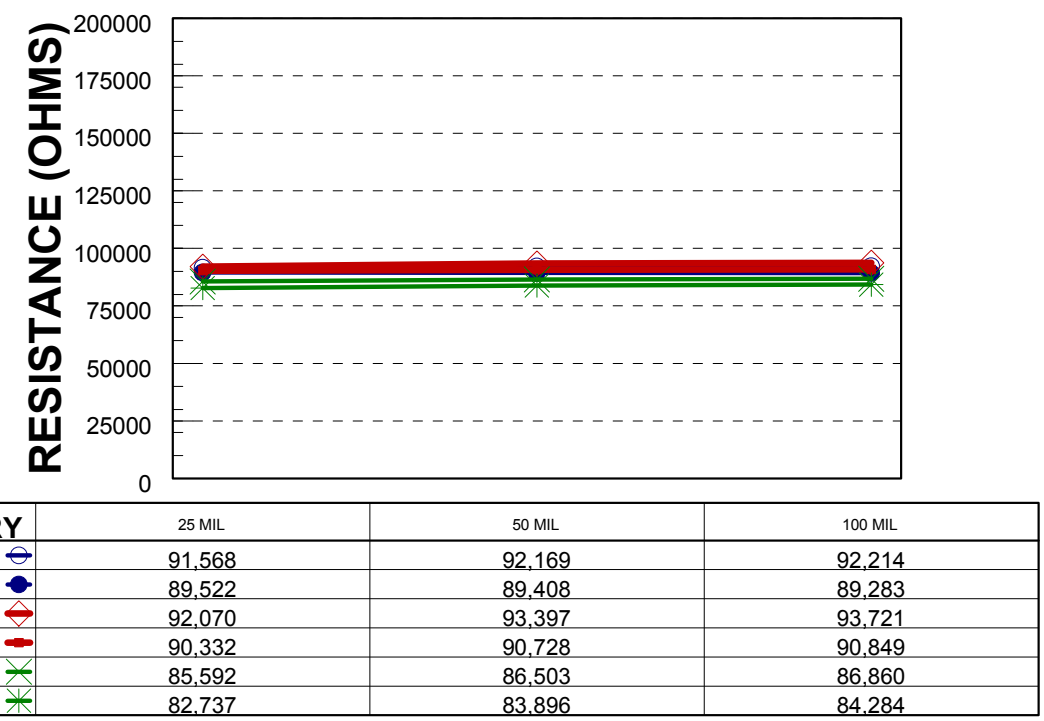

Nominal normalized resistance is 100,000 ohms.

Target Dried Thickness is $18-20$ microns

Samples fired in 22

Figure G-5. Normalized Sheet Resistance (Resistance, 100K ohm)

\section{NORMALIZED SHEET RESISTANCE DUPONT 18 (100K OHMS PER SQUARE)}

Percent from Nominal - Printed on Alumina

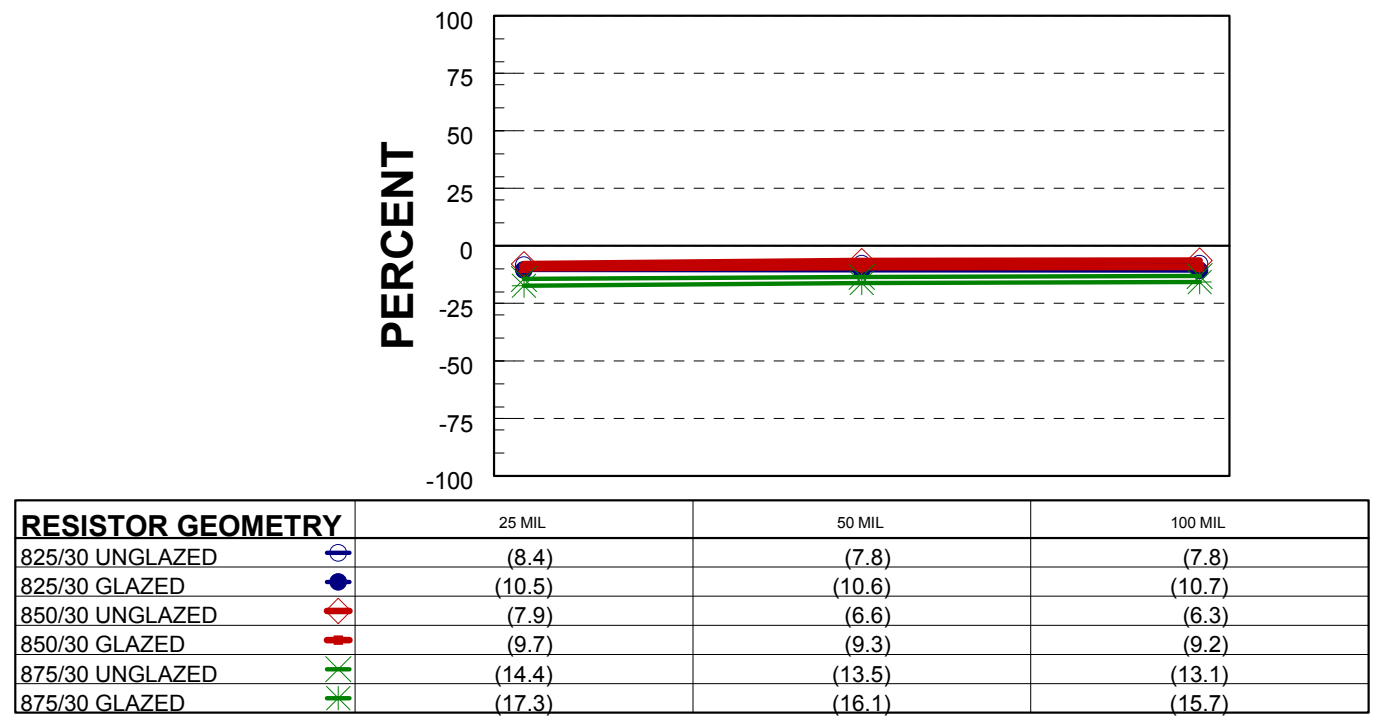

Nominal normalized resistance is 100,000 ohms.

Target Dried Thickness is $18-20$ microns

Samples fired in 22

Figure G-6. Normalized Sheet Resistance (Percent, 100K ohm) 


\section{NORMALIZED SHEET RESISTANCE DUPONT 18 (100K OHMS PER SQUARE) \\ Actual Values - Printed on Alumina}

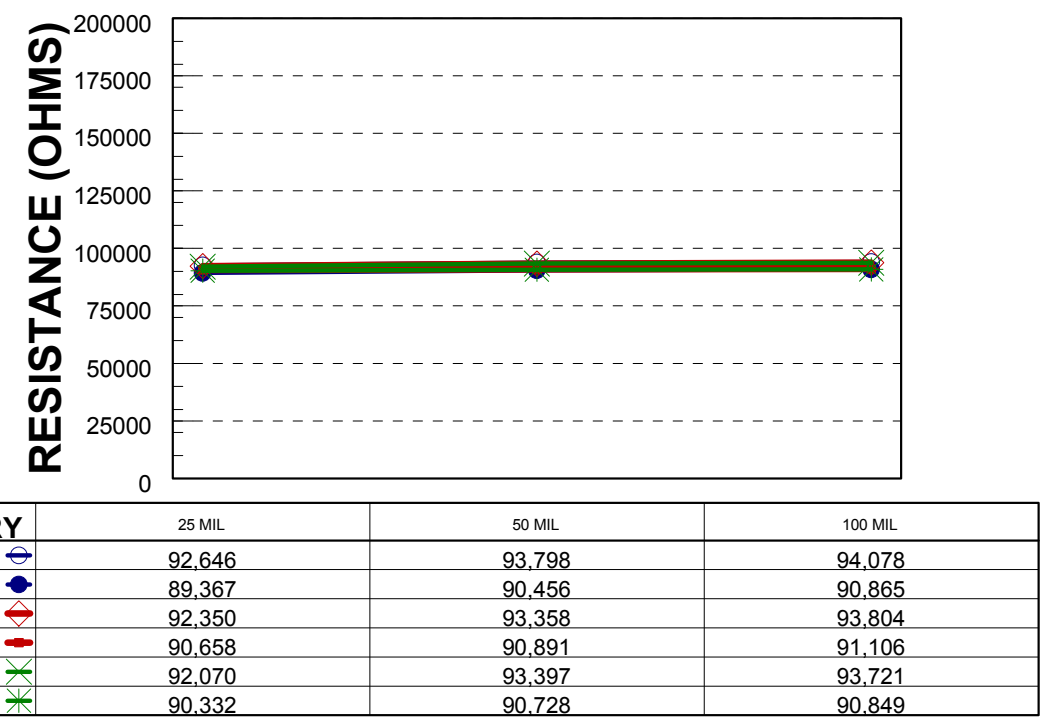

Nominal normalized resistance is 100,000 ohms.

Target Dried Thickness is $18-20$ microns

Samples fired with $850 / 30$ profile

Figure G-7. Normalized Sheet Resistance (Resistance, 100K ohm)

\section{NORMALIZED SHEET RESISTANCE DUPONT 18 (100K OHMS PER SQUARE)}

Percent from Normalized Nominal - Printed on Alumina

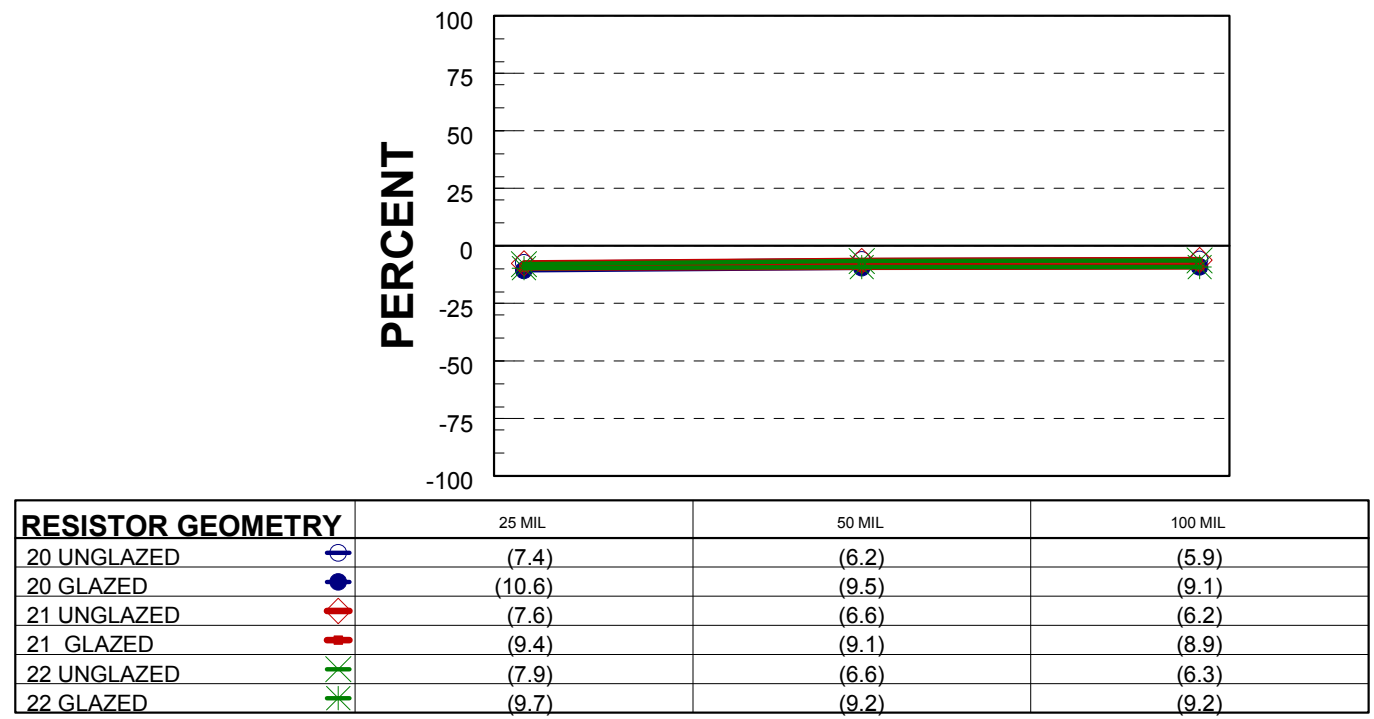

Nominal normalized resistance is 100,000 ohms.

Target Dried Thickness is $18-20$ microns

Samples fired with $850 / 30$ profile

Figure G-8. Normalized Sheet Resistance (Percent, 100K ohm) 


\section{THICKNESS \& RESISITIVITY COMPARISON DUPONT 18 (100K OHMS PER SQUARE)}

Actual Values - Printed on Alumina

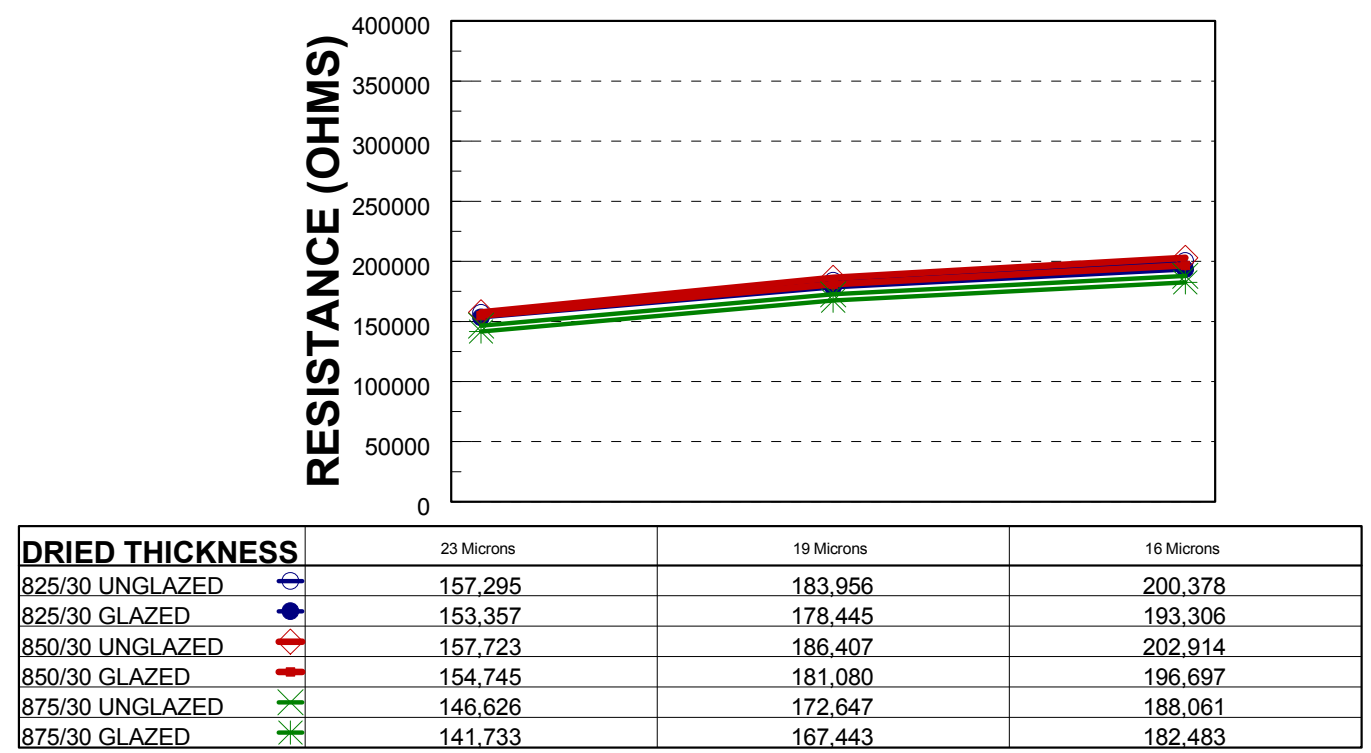

Target Dried Thickness is $18-20$ microns

Samples fired in 22

Figure G-9. Thickness and Resistivity Comparison (Resistance, 100K ohm)

\section{THICKNESS \& RESISITIVITY COMPARISON} DUPONT 18 (100K OHMS PER SQUARE)

Percent from Nominal - Printed on Alumina

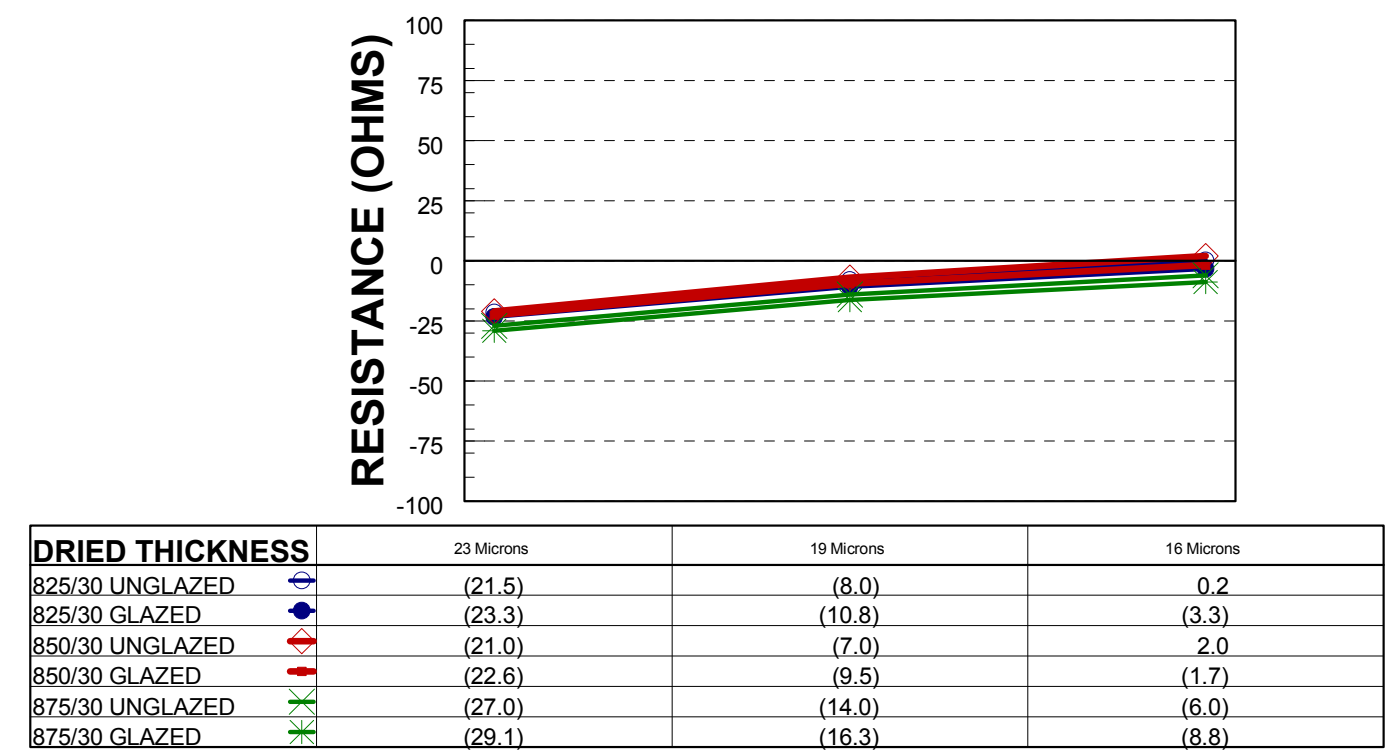

Target Dried Thickness is $18-20$ microns

Samples fired in 22

Figure G-10. Thickness and Resistivity Comparison (Resistance, 100K ohm) 


\section{THICKNESS RELATIONSHIP DUPONT 18 (100K OHMS PER SQUARE)}

Printed on Alumina

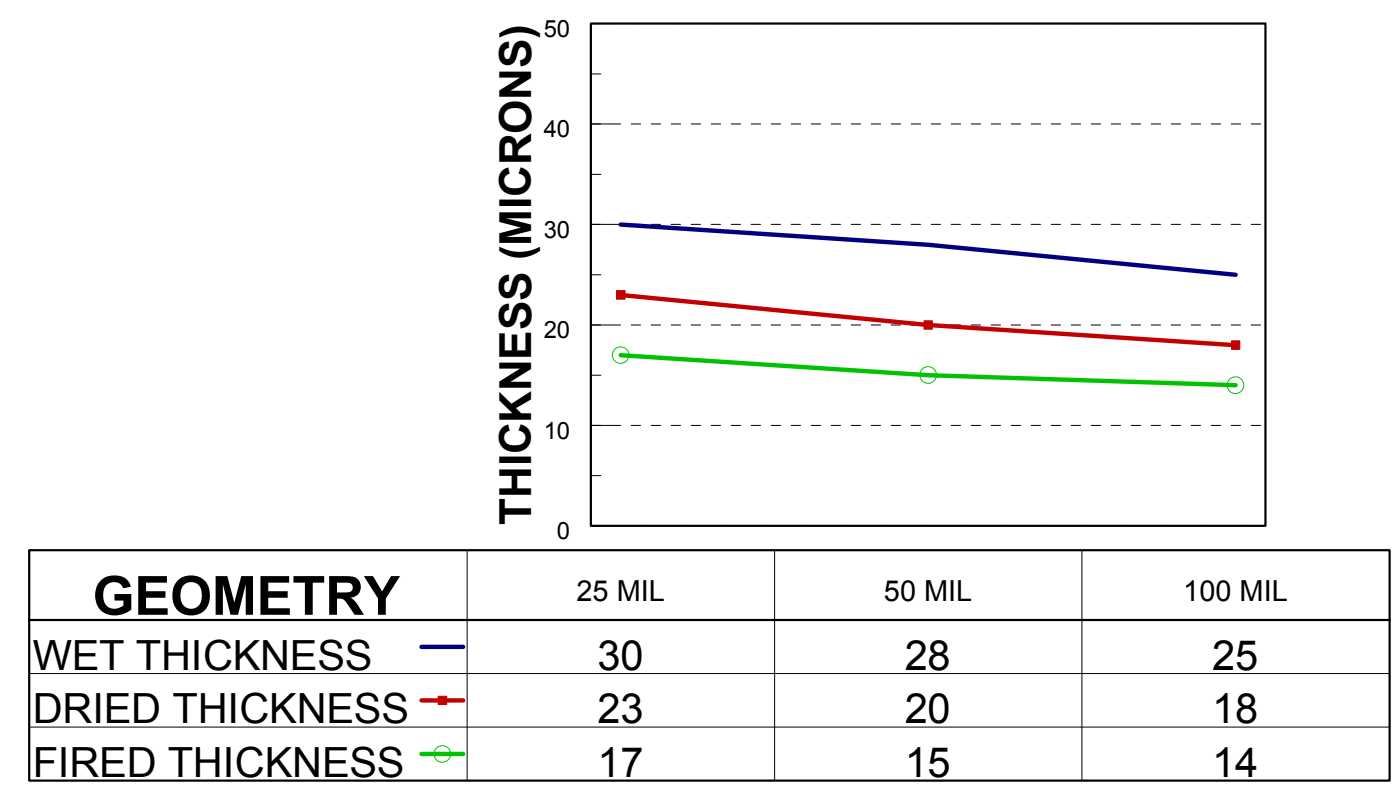

Target Dried Thickness is $18-20$ microns

Figure G-11. Thickness Relationship 


\title{
Appendix $\mathbf{H}$
}

\section{DUPONT 19 RESISTOR PRINTING DATA \\ ON ALUMINA}

\author{
(1 MEG Ohm)
}




\section{FIRING PROFILE SENSITIVITY DUPONT 19 (1MEG OHM PER SQUARE)}

Actual Values - Printed on Alumina

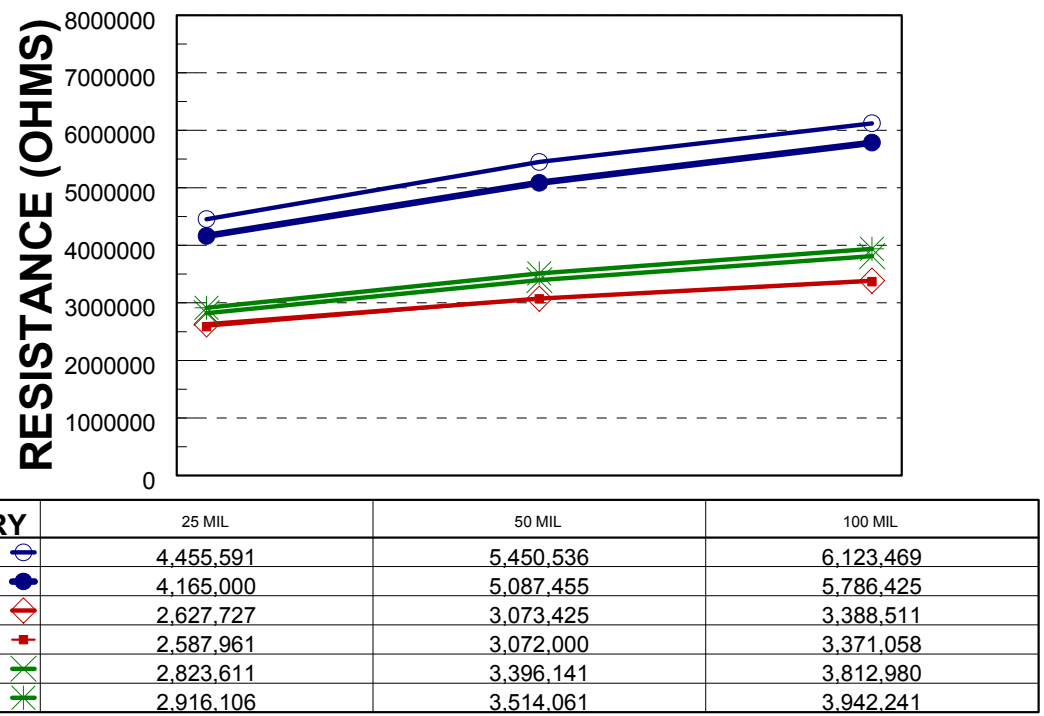

Nominal as-fired resistance is $2,000,000$ ohms.

Target Dried Thickness is $18-20$ microns

Samples fired in 22

Figure H-1. Firing Profile Sensitivity (Resistance, 1 meg ohm)

\section{FIRING PROFILE SENSITIVITY DUPONT 19 (1MEG OHM PER SQUARE)}

Percent from Nominal Values - Printed on Alumina

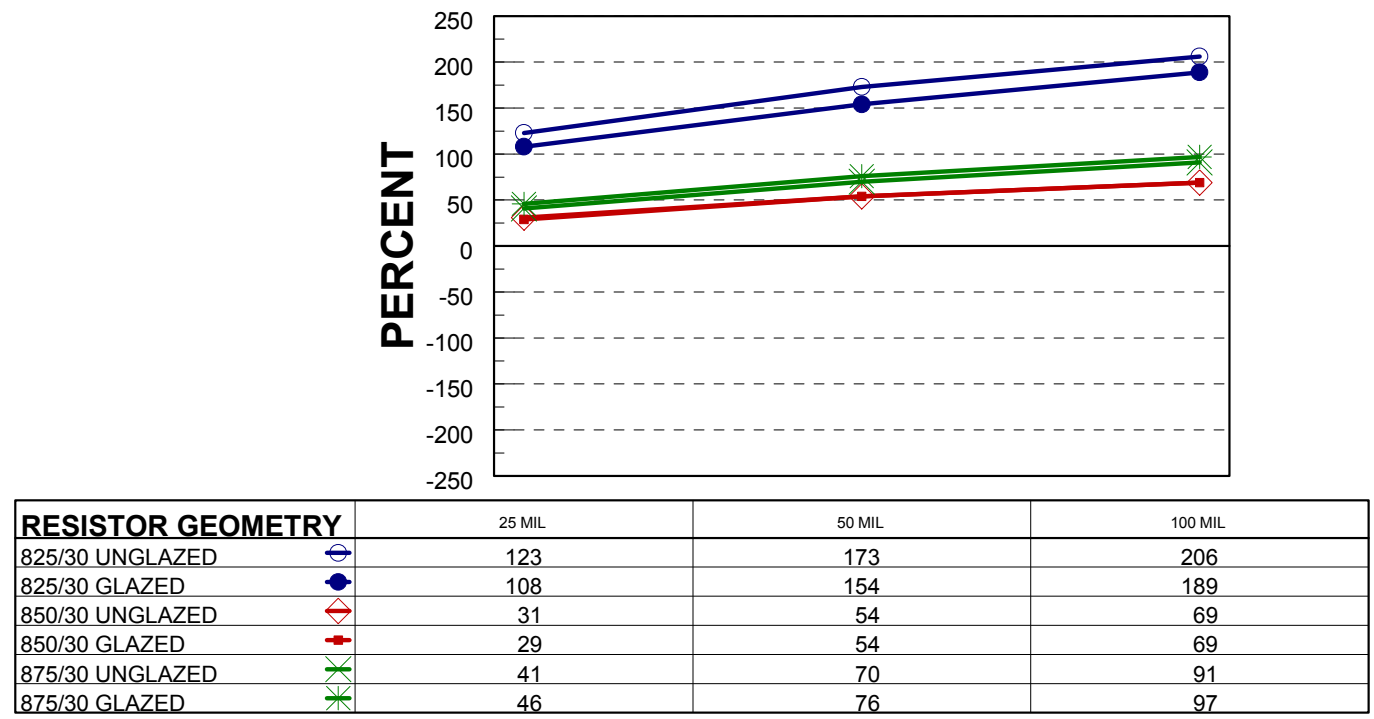

Nominal as-fired resistance is $2,000,000 \mathrm{ohms}$

Target Dried Thickness is $18-20$ microns

Samples fired in 22

Figure H-2. Firing Profile Sensitivity (Percent, $1 \mathrm{meg}$ ohm) 


\section{FURNACE SENSITIVITY DUPONT 19 (1MEG OHM PER SQUARE)}

Actual Values - Printed on Alumina

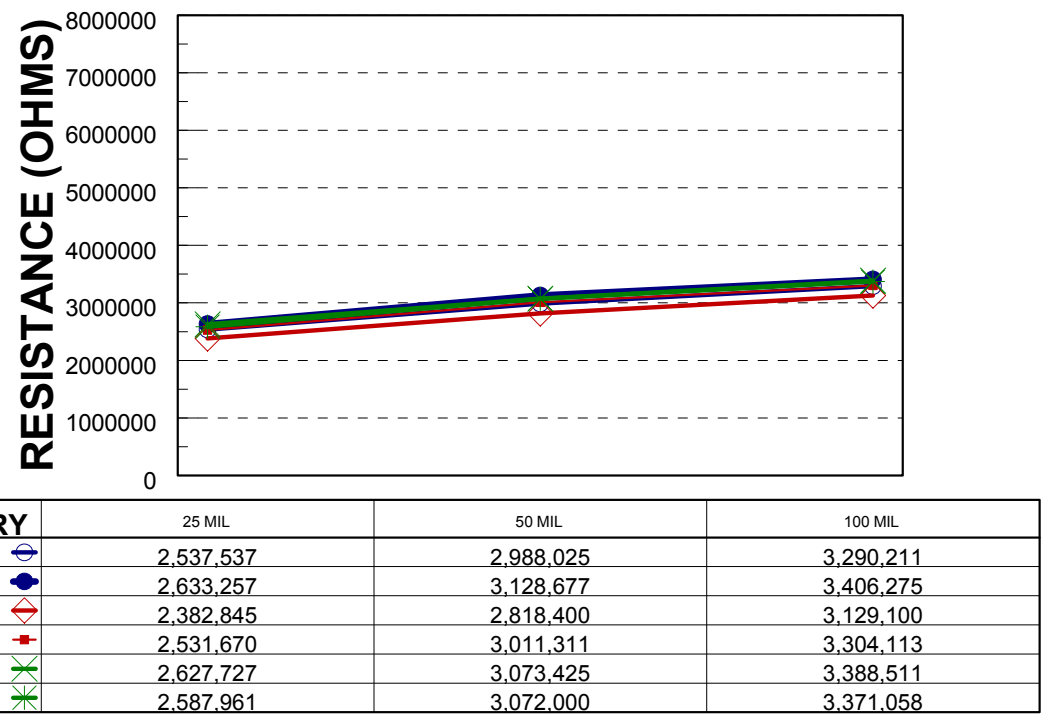

Nominal as-fired resistance is $2,000,000$ ohms.

Target Dried Thickness is $18-20$ microns

Samples fired with $850 / 30$ profile

Figure H-3. Furnace Sensitivity (Resistance, $1 \mathrm{meg} \mathrm{ohm}$ )

\section{FURNACE SENSITIVITY DUPONT 19 (1MEG OHM PER SQUARE)}

Percent from Nominal Values - Printed on Alumina

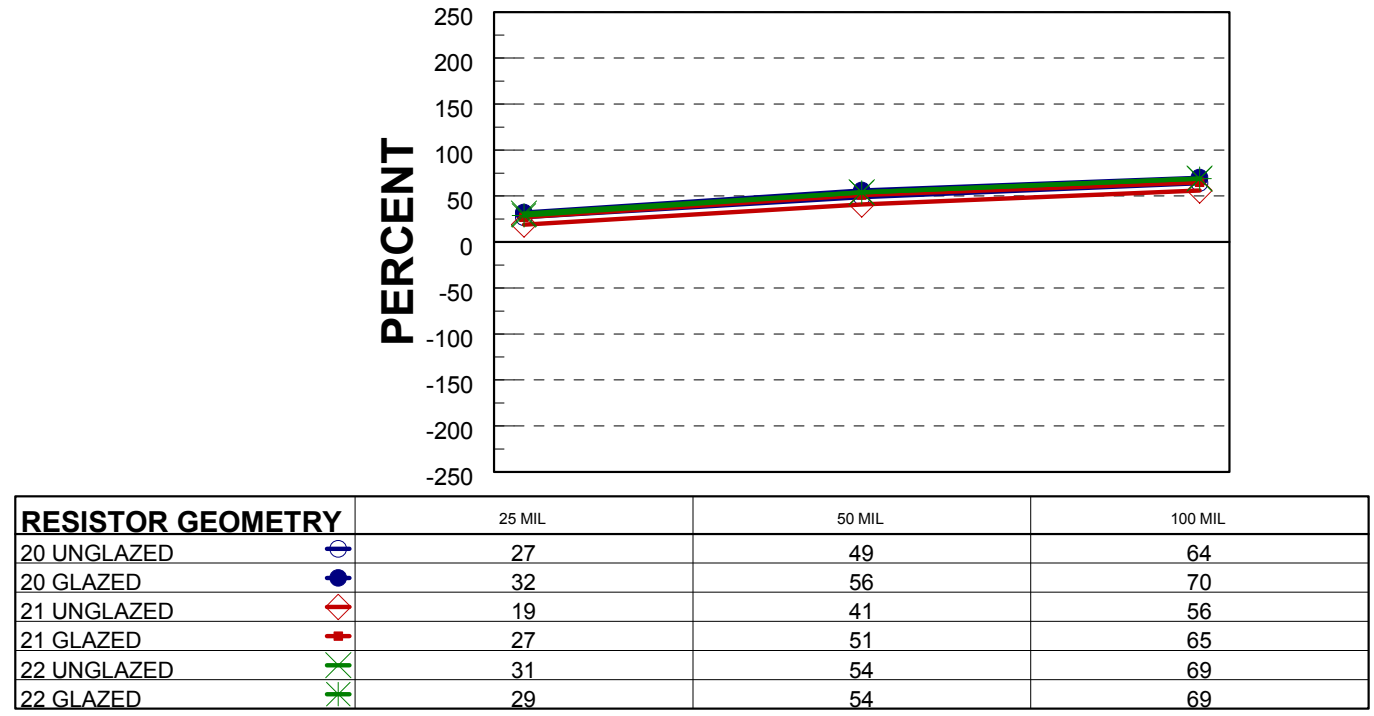

Nominal as-fired resistance is $2,000,000$ ohms.

Target Dried Thickness is $18-20$ microns

Samples fired with $850 / 30$ profile

Figure H-4. Furnace Sensitivity (Percent, 1 meg ohm) 


\section{NORMALIZED SHEET RESISTANCE DUPONT 19 (1MEG OHM PER SQUARE)}

Actual Values - Printed on Alumina

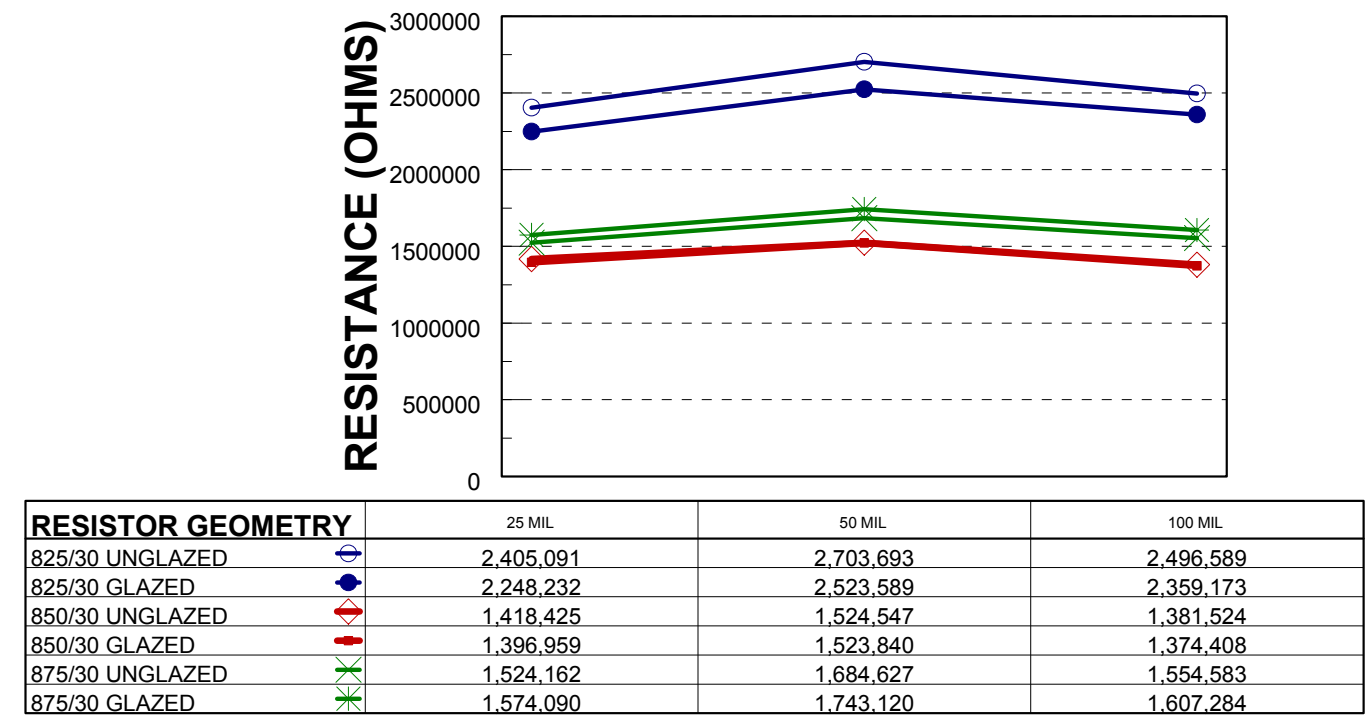

Nominal normalized resistance is $1,000,000$ ohms.

Target Dried Thickness is $18-20$ microns

Samples fired in 22

Figure H-5. Normalized Sheet Resistance (Resistance, 1 meg ohm)

\section{NORMALIZED SHEET RESISTANCE DUPONT 19 (1MEG OHM PER SQUARE)}

Percent from Nominal - Printed on Alumina

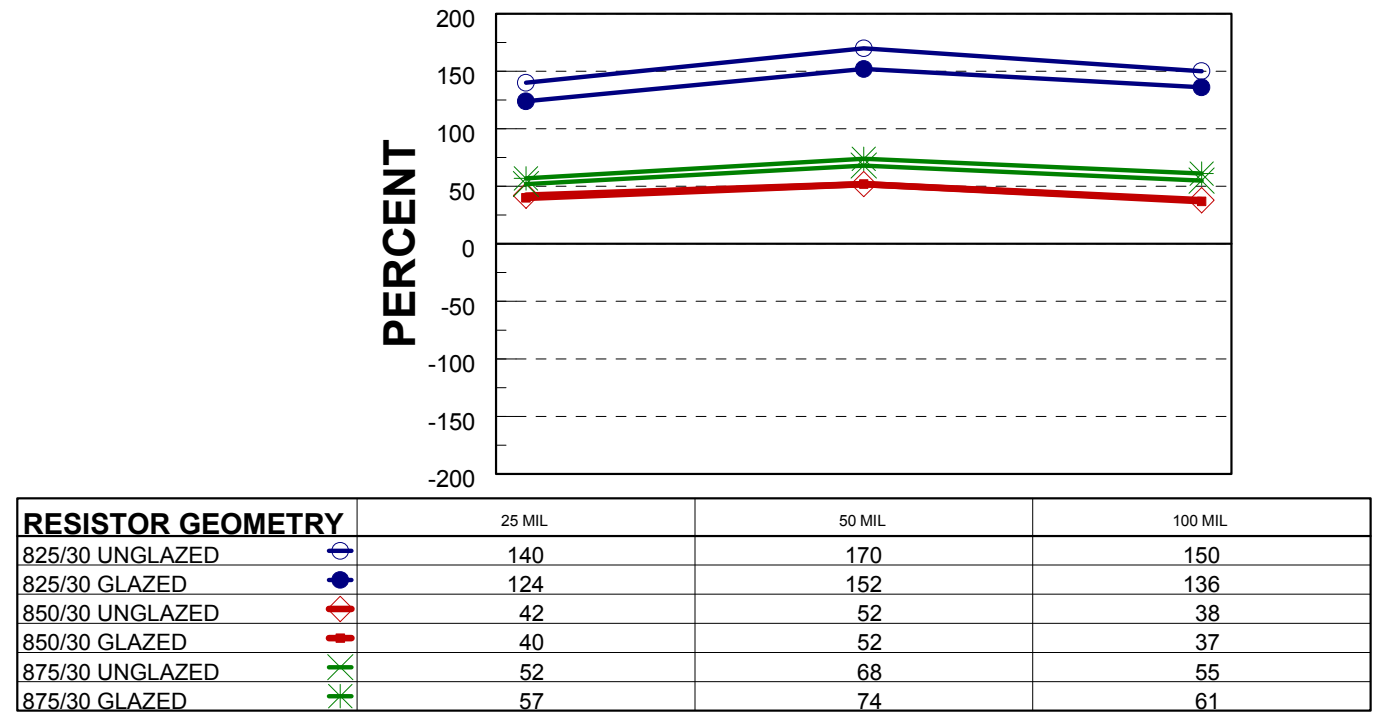

Nominal normalized resistance is $1,000,000$ ohms.

Target Dried Thickness is $18-20$ microns

Samples fired in 22

Figure H-6. Normalized Sheet Resistance (Percent, 1 meg ohm) 


\section{NORMALIZED SHEET RESISTANCE DUPONT 19 (1MEG OHM PER SQUARE)}

Actual Values - Printed on Alumina

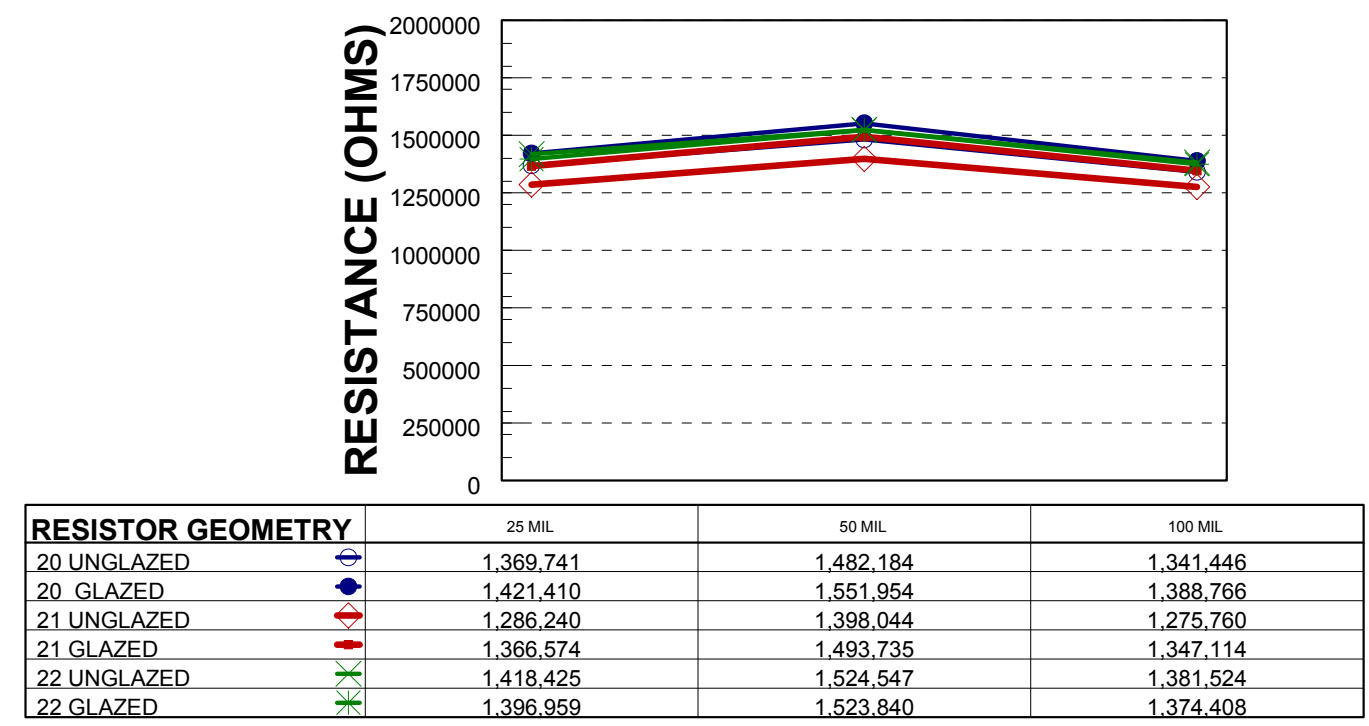

Nominal normalized resistance is $1,000,000$ ohms.

Target Dried Thickness is $18-20$ microns

Samples fired with $850 / 30$ profile

Figure H-7. Normalized Sheet Resistance (Resistance, $1 \mathrm{meg}$ ohm)

\section{NORMALIZED SHEET RESISTANCE DUPONT 19 (1MEG OHM PER SQUARE)}

Percent from Normalized Nominal - Printed on Alumina

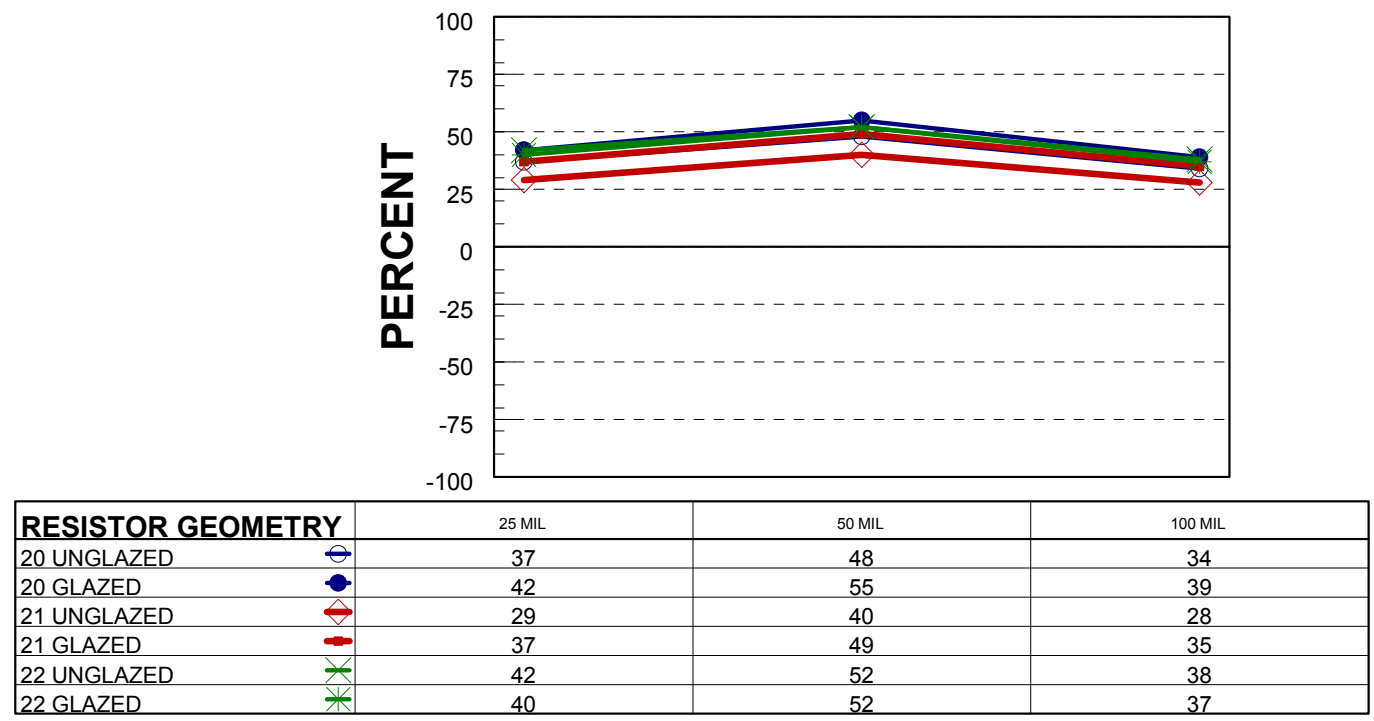

Nominal normalized resistance is $1,000,000$ ohms.

Target Dried Thickness is $18-20$ microns

Samples fired with $850 / 30$ profile

Figure H-8. Normalized Sheet Resistance (Percent, 1 meg ohm) 


\section{THICKNESS \& RESISITIVITY COMPARISON DUPONT 19 (1MEG OHM PER SQUARE)}

Actual Values - Printed on Alumina

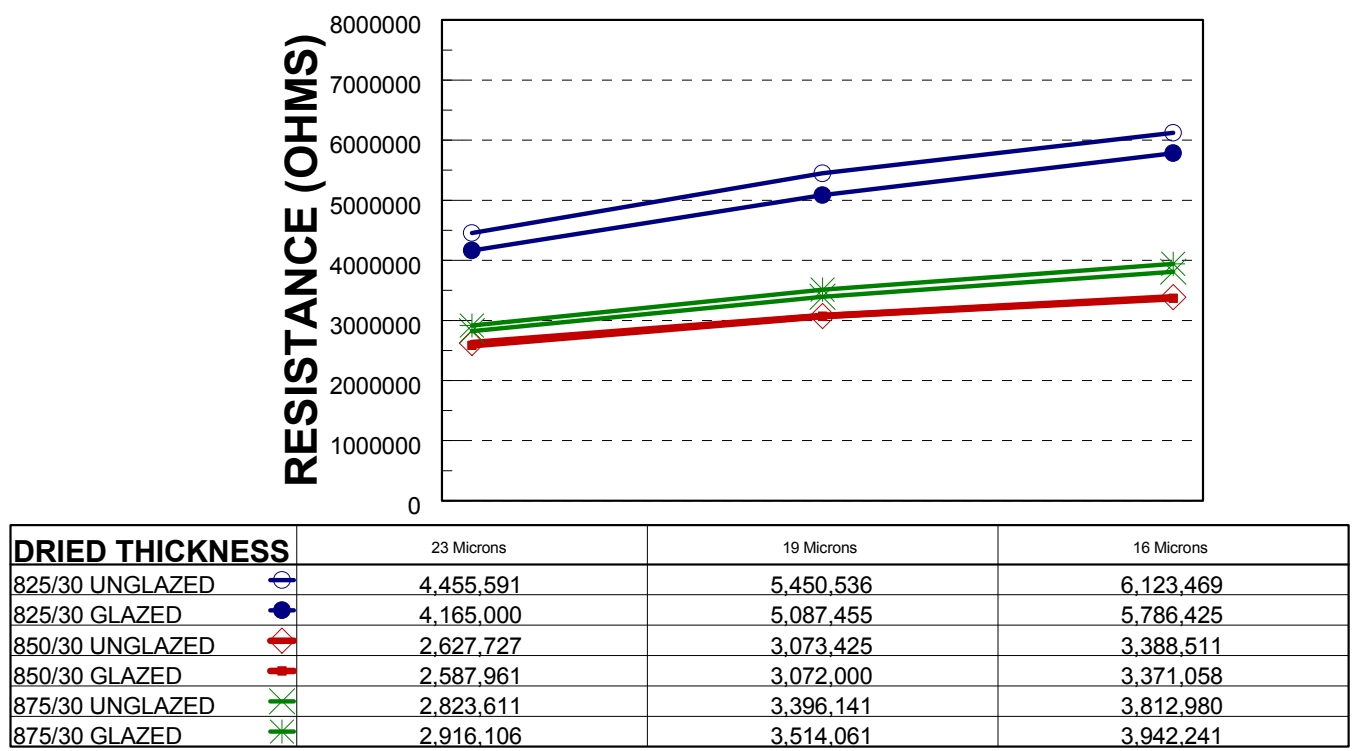

Target Dried Thickness is $18-20$ microns

Samples fired in 22

Figure H-9. Thickness and Resistivity Comparison (Resistance, 1 meg ohm)

\section{THICKNESS \& RESISITIVITY COMPARISON DUPONT 19 (1MEG OHM PER SQUARE)}

Percent from Nominal - Printed on Alumina

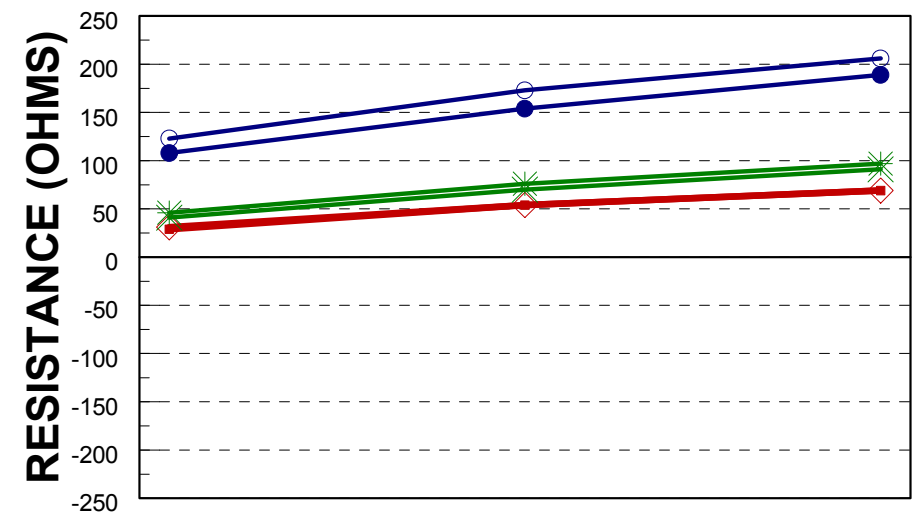

\begin{tabular}{|l|c|c|c|}
\hline DRIED THICKNESS & 23 Microns & 19 Microns & 16 Microns \\
\hline $825 / 30$ UNGLAZED & 123 & 173 & 206 \\
\hline $825 / 30$ GLAZED & 108 & 154 & 189 \\
\hline $850 / 30$ UNGLAZED & 31 & 54 & 69 \\
\hline $850 / 30$ GLAZED & 29 & 54 & 69 \\
\hline $875 / 30$ UNGLAZED & 41 & 70 & 91 \\
\hline $875 / 30$ GLAZED & 46 & 76 & 97 \\
\hline
\end{tabular}

Target Dried Thickness is $18-20$ microns

Samples fired in 22

Figure H-10. Thickness and Resistivity Comparison (Resistance, $1 \mathrm{meg}$ ohm) 


\section{THICKNESS RELATIONSHIP DUPONT 19 (1MEG OHM PER SQUARE)}

Printed on Alumina

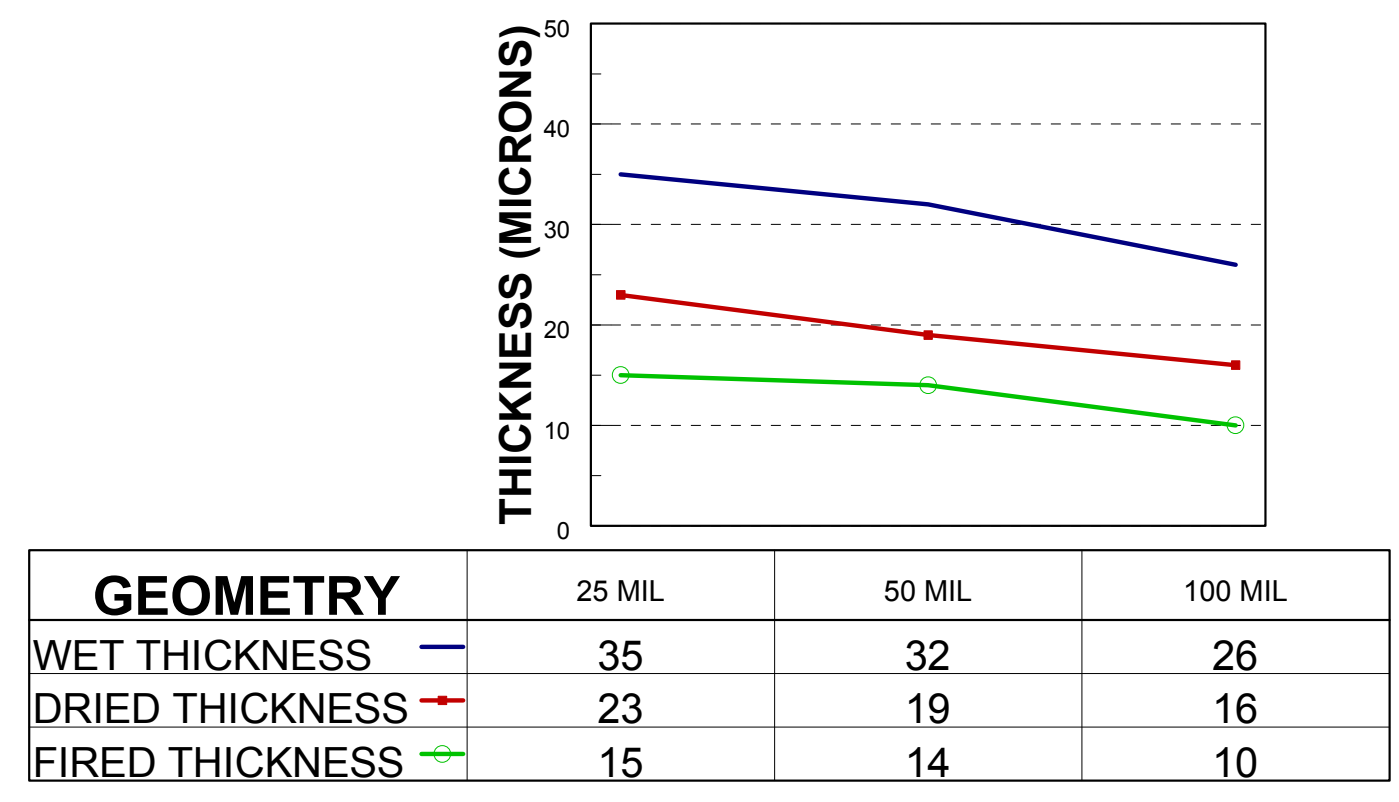

Target Dried Thickness is $18-20$ microns

Figure H-11. Thickness Relationship 